Lucas Elyseu Rocha Narcizo Mendes

\title{
A Arte de Quadrinizar o Conhecimento Escolar de Geografia
}

\section{Dissertação de Mestrado}

Dissertação apresentada como requisito parcial para obtenção do grau de Mestre em Geografia pelo Programa de Pós-graduação em Geografia, do Departamento de Geografia e Meio Ambiente da PUC-Rio.

Orientadora: Prof ${ }^{a}$ Rejane Cristina de Araújo

Rodrigues 


\section{Lucas Elyseu Rocha Narcizo Mendes}

\section{A Arte de Quadrinizar o Conhecimento Escolar de Geografia}

Dissertação apresentada como requisito parcial para obtenção do grau de Mestre pelo Programa de Pósgraduação em Geografia da PUC-Rio. Aprovada pela Comissão Examinadora abaixo:

Prof ${ }^{\mathrm{a}}$ Rejane Cristina de Araujo Rodrigues Orientadora Departamento de Geografia e Meio Ambiente - PUC-Rio

Prof. Dr. Ivaldo Gonçalves de Lima UFF

Prof. Dr. João Luiz de Figueiredo Silva ESPM

Prof ${ }^{a}$. Ana Brasil Machado

PUC-Rio

Rio de Janeiro, 28 de abril de 2021 
Todos os direitos reservados. É proibida a reprodução total ou parcial do trabalho sem autorização da universidade, do autor e da orientadora.

\section{Lucas Elyseu Rocha Narcizo Mendes}

Especialização lato senso em Metodologia do Ensino de Geografia pela Faculdade Santo André em Vilhena/RO. Licenciado em Geografia pela Universidade Federal Fluminense

- UFF - campus de Campos de Goytacazes/RJ. Ex Bolsista

CNPq PIBID e PIBIC na licenciatura em Geografia da Universidade Federal Fluminense - UFF - campus de Campos de Goytacazes/RJ. Ensino Fundamental Colégio de São Bento Rio de Janeiro. Certificado proficiência equivalente à conclusão do ensino médio pelo Instituto Federal de Educação, Ciência e Tecnologia do Rio de Janeiro.

Ficha Catalográfica

Mendes, Lucas Elyseu Rocha Narcizo

A Arte de Quadrinizar o Conhecimento Escolar de Geografia

/ Lucas Elyseu Rocha Narcizo Mendes ; orientadora: Rejane Cristina de Araujo Rodrigues. - 2021.

101 f. : il. color. ; $30 \mathrm{~cm}$

Dissertação (mestrado)-Pontifícia Universidade Católica do Rio de Janeiro, Departamento de Geografia e Meio Ambiente, 2021.

Inclui bibliografia

1. Geografia e Meio Ambiente - Teses. 2. Ensino de Geografia. 3. História em quadrinhos. 4. Giro decolonial. 5. Geopolítica popular. 6. Arte de quadrinizar. I. Bruni, Rejane Rodrigues Guedes. II. Pontifícia Universidade Católica do Rio de Janeiro. Departamento de Geografia e Meio Ambiente. III. Título. 


\section{Agradecimentos}

A minha esposa Emille Rocha que sempre com sua tranquilidade guiou meu pensamento para concluir este trabalho.

Ao meu filho Rudá que está para nascer.

Agradeço também a minha mãe Ludmilla Elyseu, pai Fabiano Narcizo e vó Rod pelo apoio incondicional nesta minha caminhada geográfica.

A meu avô Geraldo, que em meio a suas andanças em Itaguaí e Paracambi, sempre me trouxe histórias em quadrinhos para colorir meu mundo.

A minha orientadora Professora Rejane Cristina de Araujo Rodrigues pelo estímulo e parceria para a realização deste trabalho.

Ao CNPq e à PUC-Rio, pelos auxílios concedidos, sem os quais este trabalho não poderia ter sido realizado.

Aos professores que participaram da Comissão Examinadora.

A todos os professores e funcionários do Departamento pelos ensinamentos e pela ajuda.

O presente trabalho foi realizado com apoio da Coordenação de Aperfeiçoamento de Pessoal de Nível Superior - Brasil (CAPES) - Código de Financiamento 001 


\section{Resumo}

Mendes, Lucas Elyseu Rocha Narcizo; Rodrigues, Rejane Cristina de Araújo. A Arte de Quadrinizar o Conhecimento Escolar de Geografia. Rio de Janeiro, 2021, 105 p. Dissertação de Mestrado - Departamento de Geografia e Meio Ambiente, Pontifícia Universidade Católica do Rio de Janeiro.

As histórias em quadrinhos quando aplicada no ensino de geografia possui e usa a imaginação com intuito de realizar algum plano através da organização dos fatos e seus significados imaginativos e criativos; manifestando "uma preocupação séria pelas personalidades e eventos do passado [...] e um desejo de entender a ordem social à luz de seus antecedentes." (TUAN, 1990, p.439). De forma a pensar uma alternativa de conhecimento iremos destacar o Giro Decolonial que é aqui entendido como uma crítica epistemológica e ontológica que traz "uma reflexão sobre nossa memória, nosso imaginário, nossa subjetividade, nossas formas de existir cotidianas." (CRUZ, 2017, p.25). Ancorados nestes princípios, através da uma atividade realizada para com os estudantes do Cap-UERJ de produção de histórias em quadrinhos, propomos a construção de um conhecimento através de um sistema "coerente e identificável de sinais comunicativos que expressam a experiência única que cada um de nós tem da vida." (BRUNETTI, 2013, p.18). Para assim, proporcionar aos envolvidos na atividade a construção de um conhecimento escolar de Geografia que permite enxergar e entender as relações de poder presentes na sociedade, conferindo capacidade para os envolvidos se posicionar como sujeitos e agentes transformadores do real.

\section{Palavras-chave}

Ensino de geografia; História em Quadrinhos, Giro Decolonial, Geopolítica Popular, Arte de Quadrinizar 


\section{Abstract}

Mendes, Lucas Elyseu Rocha Narcizo; Rodrigues, Rejane Cristina de Araújo. The Art of Quadrinizing School Knowledge of Geography. Rio de Janeiro, 1999, 105 p. Master's Thesis - Department of Geography and Environment, Pontifical Catholic University of Rio de Janeiro.

Comic books when applied to geography teaching have and use imagination in order to carry out some plan through the organization of facts and their imaginative and creative meanings; manifesting "a serious concern for the personalities and events of the past ... and a desire to understand the social order in the light of their background." (TUAN, 1990, p.439). In order to think about an alternative of knowledge, we will highlight the Decolonial Giro, which is understood here as an epistemological and ontological criticism that brings "a reflection on our memory, our imaginary, our subjectivity, our daily ways of existing." (CRUZ, 2017, p.25). Anchored in these principles, through an activity carried out with Cap-UERJ students in the production of comic books, we propose the construction of knowledge through a "coherent and identifiable system of communicative signs that express the unique experience that each of we have of life. " (BRUNETTI, 2013, p.18). To do so, provide those involved in the activity with the construction of a school knowledge of Geography that allows them to see and understand the power relationships present in society, providing the ability for those involved to position themselves as subjects and agents that transform the real.

\section{Keywords}

Geography teaching; comic books; decolonial turning. 


\section{Sumário}

1 Introdução

2 Conhecimento geográfico, geopolítica popular, giro decolonial \& histórias em quadrinhos

3 Aprendizagem significativa e conhecimento poderoso: um diálogo potente para o ensino de geografia decolonial

4História em quadrinhos e ensino de geografia decolonial

5 Nem tudo é teoria: a arte de quadrinizar o conhecimento escolar de geografia decolonial

5.1 Uma proposta para quadrinizar o conhecimento escolar de geografia decolonial

5.1.1 Resultados alcançados

5.1.1.1 Oficina a Arte de Quadrinizar o conhecimento escolar de geografia decolonial

5.1.1.2 Gritos grupo A

5.1.1.3 Gritos grupo B

5.1.1.4 Resultados alcançados grupo A \& B

6 Considerações finais

7 Referências 


\section{Lista de figuras}

$\begin{array}{ll}\text { Figura } 1 \text { Desertistão I } & 30\end{array}$

$\begin{array}{ll}\text { Figura } 2 \text { Desertistão II } & 31\end{array}$

Figura 3 Transição 34

Figura 4 Localização dos pontos nipo-americanos 36

Figura 5 Campo Rohwer 37

Figura 6 Tábuas $\quad 39$

Figura 7 Mais um ato desumano 63

Figura 8 Conhecimento Escolar I 63

Figura 9 Conhecimento Escolar II 68

Figura 10 Impacto Ambiental I $\quad 69$

Figura 11 Impacto Ambiental II $\quad 70$

$\begin{array}{ll}\text { Figura } 12 \text { Racismo I } & 71\end{array}$

Figura 13 Racismo II 72

$\begin{array}{ll}\text { Figura } 14 \text { Violência contra mulher } & 73\end{array}$

$\begin{array}{ll}\text { Figura } 15 \text { Invasão europeia } & 74\end{array}$

$\begin{array}{ll}\text { Figura } 16 \text { Racismo III } & 74\end{array}$

$\begin{array}{ll}\text { Figura } 17 \text { Preonceito no futebol } & 75\end{array}$

Figura 18 Impacto Ambiental III 76

Figura 19 Precariedade do sistema de saúde pública I 76

Figura 20 Precariedade do sistema de saúde pública II 77

$\begin{array}{ll}\text { Figura } 21 \text { Identidade } & 78\end{array}$

$\begin{array}{ll}\text { Figura } 22 \text { Racismo IV } & 78\end{array}$ 


\section{Gráficos}

Gráfico 1 - Grito dos estudantes na atividade a arte de quadrinizar o conhecimento escolar de geografia 
O velho é novo

O novo é velho É como o ovo

E a galinha A culpa é nossa A culpa é minha.

Alceu Valença $\mathrm{O}$ ovo e a galinha 


\section{1 \\ Introdução}

Ao usar a história em quadrinhos como ferramenta de análise geográfica, assumimos como afirma Yi-Fu Tuan (1990), que cada indivíduo possui e usa sua imaginação com intuito de realizar algum plano através da organização dos fatos e seus significados imaginativos e criativos. Realização que quando associada ao conhecimento geográfico por meio da fantasia "é vista como única e essencialmente humana" (TUAN, 1990, p. 438), pois, manifesta "uma preocupação séria pelas personalidades e eventos do passado [...] e um desejo de entender a ordem social atual à luz de seus antecedentes". (TUAN, 1990, p. 439).

Fazendo com que o conhecimento geográfico não carregue apenas "mapas mentais do espaço geográfico em suas cabeças, mas também podem transcrevê-los em palavras, diagramas e mapas quando necessário" (TUAN, 1990, p. 441). Transcrição que promove a "sensação de um mundo compartilhado" (TUAN, 1990, p. 441), que permite a libertação do indivíduo da "cultura estabelecida" (TUAN, 1990, p. 443).

Dessa maneira, ao compreender a arte como um elemento para se pensar o conhecimento geográfico, se assume que ela é importante, pois, permite o desenvolvimento de uma visão de mundo construtora de "um conhecimento semelhante ao da ciência empírica [...] isto é, para mostrar a inserção da vida em um ambiente ou paisagem" (TUAN, 1990, p. 444), que faz com que o conhecimento geográfico não seja apenas um "conhecimento básico adquirido das necessidades da vida; é também um projeto intelectual-imaginativo". (TUAN, 1990, p. 444).

Entretanto, estamos imersos em um sistema-mundo, que para Dussel (1977), através da aplicação de uma filosofia de centro, hegemônica e ideológica, articula interesses que justificam a dominação do ser. Produzindo desejos e necessidades, que criam uma história linear e universal, que tem como eixos centrais de sua configuração, segundo Quintero (2019); um sistema de dominação cultural controlador da produção e reprodução da subjetividade, que para Lestesgás (2002), difunde redes técnicas e informacionais, que reduz a folclore quaisquer manifestação de diversidade cultural e linguística diferente. 
Esta difusão é concebida através de uma visão de mundo que é estruturada por meio de um sistema de exploração social e global, que articula formas de controle institucionalizadas e justificadas pelo poder hegemônico (QUINTERO, 2019; LIMA, 2013). No qual através da perpetuação de práticas e relações de poder coloniais (colonialidade do poder), insere indivíduos na sociedade através destas relações (colonialidade do ser), sendo este êxito proporcionado por um conhecimento produzido que se encontra subalternizado frente ao conhecimento moderno Ocidental (colonialidade do saber).

Assim sendo, o conhecimento geográfico esteve a serviço deste sistema de exploração social e global, imprimindo novas formas de organizar o espaço, construindo um conhecimento que justifica e legitima interesses imperialistas por meio de uma cultura intitulada como superior (GOTTMAN, 1947; CAPEL, 2012; LESTESGÁS, 2002). No qual insere o conhecimento geográfico como um instaurador de um poder colonial interno e global, estabelecendo vínculos que reconhecem, classificam e hierarquizam outros conhecimentos, pondo-os a serviço de atores hegemônicos imersos em determinados regimes de poder (SANTOS, 2017).

Esta instauração de poder através do conhecimento, tem como marco o ano de 1492; com a invasão do europeu à América, construindo um conhecimento que põe a perspectiva e subjetividade europeia (depois norte-americana) como centro de uma História Mundial. Para então dividir o mundo em: i) Europa/(depois)Estados Unidos desenvolvidos, ii) América Latina imatura, iii) África ausente de desenvolvimento histórico e iv) Ásia com papel introdutório e preparatório no desenvolvimento da história mundial (DUSSEL, 1977; 2016; 1993).

Divisão do mundo que traz a luz do significado ontológico do ano de 1492, ou seja, uma construção ideológica construída a partir da imagem e semelhança para com a Europa (Estados Unidos depois), que põem desde sempre o outro não moderno como ser de alteridade negada, submetidos a um processo de modernização criador de uma cultura superior e desenvolvida (DUSSEL, 1993).

Como meio de se pensar uma alternativa de conhecimento que permita, como destacado por Sassen (2003) apud Lima (2013), aplicar uma imaginação construtora de novas espacialidades, iremos destacar o giro decolonial, que é aqui 
entendido como uma crítica ${ }^{1}$ epistemológica e ontológica que traz "uma reflexão sobre nossa memória, nosso imaginário, nossa subjetividade, nossas formas de existir cotidianas". (CRUZ, 2017, p. 25).

Assim sendo, no primeiro capítulo buscamos entender como o conhecimento moderno condiciona de forma direta na construção do conhecimento geográfico. Como também - através de um diálogo entre o Giro Decolonial e Geopolítica Popular - explorar suas respectivas potencialidades de forma a pensar a construção de um conhecimento geográfico que entende que o conhecimento não se limita apenas a um "ato privilegiado de interpretação acadêmica" (DOODS, 2002, p. 194), mas um ato criador de possibilidades de se pensar a construção do conhecimento de forma a romper com o conhecimento estruturado através do significado ontológico do ano de 1492. Mostrando que quando usadas para se pensar um conhecimento geográfico decolonial através da geopolítica popular, as histórias em quadrinhos, carregam em sua estrutura "uma análise geral usada ocasionalmente para esclarecer questões específicas" (DOODS, 2002, p. 171).

Desta forma, ao se pensar um conhecimento escolar de geografia, por meio da geopolítica popular e do giro decolonial, se vê necessário o reconhecimento das respectivas potencialidades, que carregam, o conhecimento prévio e especializado a ponto de contribuir para o desenvolvimento do mesmo.

Esta inter-relação é importante, porque o conhecimento prévio se desenvolve por meio de trocas constantes entre significados e sentimentos que juntos, proporcionando a manifestação de "uma disposição para relacionar o novo material de modo substantivo e não arbitrário a sua estrutura de conhecimento" (MOREIRA, 2011, p. 36). Entretanto, é necessário que junto do desenvolvimento do conhecimento prévio, se desenvolva também um conhecimento especializado que venha a reconhecer as decisões sobre a construção do conhecimento dadas pela recontextualização (YOUNG, 2016).

Desse modo - no terceiro capítulo: "Aprendizagem significativo e conhecimento poderoso: um diálogo potente para o ensino de geografia decolonial" - propomos de forma a não negar o conhecimento já existente; o

1 Crítica que tem como objetivo contribuir para o desenvolvimento de "outras racionalidades, culturas, subjetividades e caminhos para o desenvolvimento da humanidade". (BARROS, 2019, p. 43), para então buscar uma estratégia "de dominação e expropriação dos conhecimentos e culturas oriundas de outros povos, não europeus". (BARROS, 2019, p. 44). 
reconhecimento de outros conhecimentos produzidos através de outras "formas de ser, pensar e conhecer diferentes da modernidade europeia, porém em diálogo com esta". (MIGNOLO, 2003 apud OLIVEIRA; CANDAU, 2010, p. 23).

Uma dessas formas pode ser dada através do uso das histórias em quadrinhos no ensino de geografia. Logo, no quarto capítulo: "História em Quadrinhos e Ensino de Geografia Decolonial", buscamos mostrar como as mesmas podem contribuir para a construção de um conhecimento escolar de geografia. Criador de novas ressignificações sobre determinado cotidiano, cultura e relações de poder, que desenvolvem de forma individual autonomia, autoexpressão, identidade e conhecimento (OSBORNE, 2007 apoud DIÓRIO; RÔÇAS, 2013, p.57).

Como forma prática de se pensar este conhecimento usamos a expressão de autoria de Ivan Brunetti (2013) - A Arte de Quadrinizar (2013) - entendida como "um meio prático pelo qual o quadrinista amador pode vir a descobrir-se criativamente". (BRUNETTI, 2013, p. 1). Descoberta que permite o estudante a captar e estruturar o mundo por meio de expressões inexploradas, que são estruturadas nas histórias em quadrinhos por um sistema "coerente e identificável de sinais comunicativos que expressam a experiência única que cada um de nós tem da vida" (BRUNETTI, 2013, p. 18).

Isto posto - a metodologia deste trabalho: Uma proposta para quadrinizar o conhecimento escolar de geografia decolonial - consiste em quatro momentos. Entretanto, é importante destacar que fora realizada com estudantes do oitavo ano do Cap-UERJ - tendo como parâmetro o currículo mínimo do Rio de Janeiro. No qual o conteúdo selecionado fora: conhecimento americano e sua diversidade, e, habilidade e competência: identificar as características étnico-culturais dos povos americanos, relacionando-as às matrizes europeia, africana e indígena na construção da identidade da população do continente americano.

Assim sendo, é importante destacar que a atividade a ser desenvolvida fora executada através do uso da Internet, devido ao fato de o ano de 2020 ter sido marcado pela COVID-19, impedindo a prática presencial com os alunos, e, para segurança de todos envolvidos no processo de ensino aprendizagem de geografia. Dessa maneira, é importante destacar que não é porque está sendo feita de forma não presencial, que perde seu valor crítico, pois, como veremos no primeiro capítulo - através da sequência de imagens referentes ao audiovisual da Turma da 
Mônica - estamos abertos para "novas formas de ação e interação no mundo social, novos tipos de relações e novas maneiras de relacionamento do indivíduo com o outro e consigo mesmo". (NICOLAU; MAGALHÃES, 2013, p. 69).

Dessa maneira, temos no primeiro momento da atividade fora feito um debate com os estudantes, mostrando o papel da mídia na construção de discursos hegemônicos condicionados pelo significado ontológico do ano de 1492, como também como uma forma de construir contranarrativas exteriores a este significado. Após, através da exposição audiovisual de Zé Carioca recebendo Pato Donald no Rio de Janeiro, mostramos elementos que mostram como a mídia se articula com a visão de mundo afim de reforçar uma visão de mundo moderna.

Já no terceiro momento da atividade, através de duas tirinhas da personagem Mafalda, buscaram-se não só elementos da história que mostram como as mídias contribuem para construção de contranarrativas, como também se mostram alguns elementos que contribuem na produção de uma história em quadrinhos, como por exemplo: expressão dos personagens, o aumento da letra para mostrar uma entonação maior na fala. No quarto momento, tivera a produção de histórias em quadrinhos, por parte dos estudantes, associando as habilidades e competências trabalhadas em sala de aula com o debate feito nos momentos posteriores da atividade. Dito isso na última subseção do último capítulo, trazemos os resultados alcançados com a atividade desenvolvida. 


\section{2 \\ Conhecimento geográfico, geopolítica popular, giro decolonial \& histórias em quadrinhos}

Anteriormente a chegada do europeu e da criação da América Latina, a região "era habitada por vários povos com língua, vestuário e costumes diversos que haviam desenvolvido eficazes sistemas de comunicação e troca de pensamentos e produtos". (CECEÑA, 2006, p. 223). Tendo a concepção de espaço dada por uma relação intersubjetiva entre homens e mulheres para com a natureza, cujo ser humano concebia a si mesmo "apenas como um dos tantos sujeitos que compunham a unidade da vida". (CECEÑA, 2006, p. 224). No . Sendo suas viagens e trocas culturais e de conhecimento encaradascomo:

uma pratica corrente e serviam para o abastecimento de produtos, mas, sobretudo, para a troca de conhecimentos e histórias, mitos e experiências. Eram um meio de enriquecimento cultural que, evidentemente, foi suspenso no momento da Conquista, ao se proibir o indígena de navegar. (CECEÑA, 2006, p. 230-231).

Assim - com a chegada do europeu a partir de 1492 - - segundo Dussel (1977) - há a exportação de suas relações de poder a. Exportação que impõe a ideia de espaço enquanto campo de batalha, construindo um pensamento oriundo de uma única realidade - que tem como referência: o homem do sexo masculino civilizador do mundo - construída por um ato de totalização que oprime e exerce através da dialética uma relação para com o outro a partir da opressão.

Ato que é justificado através da criação do que Dussel denominou de significado ontológico do ano de 1492, que põe o homem do sexo masculino europeu com a missão "divina" de civilizar o mundo, através de uma filosofia de centro, hegemônica e ideológica que se articula a interesses dominantes que justificam a dominação do ser. Desenvolvendo um sistema dominante produtor de desejos e necessidades, que tem como objetivo: criar uma história linear e universal que tem como fim o europeu civilizado-moderno; forjando assim as figuras históricas do sujeito colonizador e do sujeito colonizado (DUSSEL, 1977).

Neste processo de dominação e opressão, o conhecimento geográfico ganha destaque, devido ao fato de a ação política sempre ser localizada e se desenvolver 
por meio de contradições; criando e desenvolvendo um "complexo de inferioridade devido ao sepultamento de sua originalidade cultural" (FANON, 2008 , p. 34), que faz com que o outro duvide de "si próprio enquanto objeto capaz de suscitar a simpatia ou o amor". (FANON, 2008, p. 78). Uma das formas de destaque se dá através do surgimento das sociedades geográficas em meados do século XIX, que . Sociedades que para Capel (2012); eram associadas a interesses imperialistas europeus que estimularam expedições de colonização pela Terra, servindo de centro de estudos de suas respectivas colônias.Portanto, servindo ao sujeito colonizador, Pondo-as imersas em um "complexo de inferioridade devido ao sepultamento de sua originalidade cultural" (FANON. 2008, p.34) e criando em torno das mesmas uma não valorização afetiva de suas respectivas existências no qual "o indivíduo duvida de si próprio enquanto objeto capaz de suscitar a simpatia ou o amor." (FANON, 2008, p.78o conhecimento geográfico é desenvolvido por diferentes interpretações a serviço dos anseios coloniais. Servindo de suporte para instauração de um poder colonial que estabelece vínculos - que segundo Santos (2017) - classificando-o, hierarquizando-o e pondo-o a serviço de atores hegemônicos que se inter-relacionam através das diferentes ideias de colonialidades que serão destacadas ao longo deste primeiro capítulo.

Esta inter-relação pode ser bem analisada no fragmento a seguir; quando a formação do homem-moderno, estabelece uma relação de apropriação com as sociedades rotuladas não modernas, condicionando suas ações (colonialidade do poder), conhecimentos (colonialidade do saber) e posicionamento no espaço (colonialidade do ser):

O mundo branco, o único honesto, rejeitava minha participação. De um homem exige-se uma conduta de homem; de mim, uma conduta de homem negro - ou pelo menos uma conduta de preto. Eu acenava para o mundo e o mundo amputava meu entusiasmo. Exigiam que eu me confinasse, que encolhesse. (FANON, 2008, p. 107).

Encolhimento que situa o indivíduo através de uma "retenção do passado, uma colocação do projeto fundamental futuro e um viver as possibilidades que dependem de tal futuro". (DUSSEL, 1977, p. 30). Criando um mundo com partes estruturadas, que possuem alguma semelhança com o "todo comportamento parcial, singular, de cada membro, sujeito, eu particular". (DUSSEL, 1977, p. 32). 
Estruturação que é composta por narrativas simbólicas dotadas de significados universais construídos por conceitos que unificam seus significados pondo o homem moderno como centro da História Mundial e portador de um status de emancipação. Unificação que se estrutura por meio da fragmentação e divisão do mundo nas seguintes partes: i) Europa (Estados Unidos) desenvolvida; ii) America Latina imatura; iii) África ausente de desenvolvimento histórico; Ásia com papel introdutório e preparatório para o desenvolvimento da história mundial (DUSSEL 2016; 1993).

Esta divisão assim, extingue outras formas de conhecer e viver o mundo, substituindo-as por processos civilizatórios do regime colonial ${ }^{2}$ (CRUZ, 2017, p. 17), que limitam e destroem "todo projeto de libertar a sociedade do poder atual e de bloquear todo caminho que possa levar à redução ou destruição de todo poder". (QUIJANO, 1988, p. 56). Para então desenvolver - através de um reino de vigilância de julgamento - exposições e análises geográficas que põem o conhecimento geográfico moderno acima dos demais conhecimentos geográficos produzidos (Ó TUATHAIL; DALBY, 2002).

Posição de superioridade frente ao outro, como apontado por Santos (2017), é mediada pela perpetuação se encontra inserido na ideia de colonialidade ${ }^{3}$ segundo o autor, são prática e relações sociais de poder calcadas e herdadas do período colonial, que perpetuam a dominação e exploração do outro não moderno, desenvolvendo um conjunto de relações de poder que põe a Europa como centro, ponto de chegada e partida, e, o outro não moderno como "aquilo que só passou a ser reconhecido através do Centro". (MALDONADO-TORRES, 2008, p. 71). À vista disso, devido a amplitude que envolve o conceito de colonialidade, destacaremos neste trabalho a colonialidade do poder, saber e ser.

Tendo na colonialidade do poder a formação de práticas sociais desenvolvidas por um constructo ideológico colonial/moderno. Cujo o fenômeno do poder é caracterizado através da co-presença da dominação, exploração e

\footnotetext{
2 É importante destacar que esse regime colonial refaz e conserva "relações coloniais com as minorias e as etnias colonizadas que se encontram no interior de suas fronteiras políticas [...] com variantes que dependem da correlação de forças dos antigos habitantes colonizados e colonizadores que conseguiram a independência”. (GONZÁLEZ CASANOVA, p. 438).

3 Colonialidade que não é única, pois, se "assenta num modo de se conceber noções de desenvolvimento e de progresso que misturam-se de acordo com um contexto determinado" (FERREIRA; CARLET, 2017, p. 1917).
} 
conflito, que se encontram diretamente associados à ideia de raça ${ }^{4}$ como fundamento do padrão universal de classificação e exploração social (QUIJANO, 2013; 2002), ou seja, "uma estrutura de poder própria do domínio colonial na qual foram submetidos os povos originários a partir de 1492, e que ainda perdura, mesmo após as independências" (cf. Quijano, 1992, p. 12)”. (SILVA; PROCÓPIO, 2019, p. 16).

Esta perpetuação:

se mantém viva em manuais de aprendizagem, nos critérios para o bom trabalho acadêmico, na cultura, no senso comum, na autoimagem dos povos, nas aspirações dos sujeitos e em muitos outros aspectos de nossa experiência moderna. Neste sentido, respiramos a colonialidade na modernidade cotidianamente. (MALDONADO-TORRES, 2007, p. 131 apud SILVA; PROCÓPIO, 2019, p. 19).

Concomitante a este padrão de exploração e dominação construídos pela ideia de colonialidade do poder, há a formação de "um modelo de poder especificamente moderno que interliga a formação racial, o controle do trabalho, o Estado e a produção de conhecimento". (QUIJANO, 2001 apud MALDONADOTORRES, 2008, p.88). Produtor de um saber situado em um contexto expresso um movimento de centralização e periferização dos saberes ${ }^{5}$, que desenvolve o controle da subjetividade dos povos dominados e oprimidos desde o período colonial (BARROS, 2019).

Controle, é aqui entendido como colonialidade do saber, ou seja, uma epistemologia de opressão criada e reproduzida através de pensamentos coloniais referentes a "experiência vivida da colonização e seu impacto na linguagem". (MALDONADO-TORRES, 2007, p. 130 apud BARROS, 2019, p. 40), que faz com que os conhecimentos produzidos nos países centrais sejam sempre considerados superiores frente aos demais conhecimentos, que por sua vez adotam

\footnotetext{
4 Para Aníbal Quijano (2005), o conceito de raça produziu nas Américas, identidades que legitimaram relações de dominação que foram impostas a partir das conquistas iniciadas no ano de 1492, naturalizando relações coloniais de dominação entre modernos e selvagens, que por sua vez estruturaram um novo padrão de poder com dependentes históricos-estruturalmente que perduram até os dias atuais.

5 Este movimento ocorre através de um reducionismo do conhecimento que faz com que uma linguagem seja "imposta como parâmetro para todas as traduções e conversões" (HARAWAY, 1995, p. 16). Imposição que faz com que seja necessário pensarmos saberes que sejam vistos como "ator e agente, não como uma tela, ou um terreno, ou um recurso, e, finalmente, nunca como um escravo do senhor que encerra a dialética apenas na sua agência e em sua autoridade de conhecimento "objetivo"'. (HARAWAY, 1995, p. 37).
} 
um "padrão eurocêntrico em sua produção do conhecimento e a valorização de sua cultura”. (BARROS, 2019, p. 40-41).

Assim sendo, este conhecimento através de uma experiência colonial, é produzido a partir de uma "relação entre modernidade e a experiência colonial" (MALDONADO-TORRES, 2008, p. 84), que conduz o indivíduo não moderno, à um processo - aqui entendido como colonialidade do ser - que:

"refere-se ao processo pelo qual o senso comum e a tradição são marcados por dinâmicas de poder de carácter preferencial: discriminam pessoas e tomam por alvo determinadas comunidades". (QUIJANO, 2000 apud MALDONADOTORRES, 2008, p. 96).

Logo, é importante destacar que esse ser não é um resultado de um autor ou filósofo x, "mas é antes o produto da modernidade/colonialidade na sua íntima relação com a colonialidade do poder, com a colonialidade do saber e com a própria colonialidade do ser". (MALDONADO-TORRES, 2008, p. 89). Deste jeito, ao pensar o conhecimento de maneira decolonial, busca-se desenvolver um conhecimento revelador, que assume uma postura crítica frente ao conhecimento produzido através da inter-relação entre a colonialidade do poder, ser e saber. Crítica que tem como principal objetivo contribuir para o desenvolvimento de "outras racionalidades, culturas, subjetividades e caminhos para o desenvolvimento da humanidade". (BARROS, 2019, p. 43).

Posto isso, ao considerar a presença da opressão e da exclusão do outro não apenas em âmbito acadêmico e institucional, como também em âmbito subjetivo, a decolonialidade possibilita a uma compreensão crítica da continuidade das formas de dominação como um processo fundamental:

de estruturação do sistema-mundo moderno/colonial, que articula os lugares periféricos da divisão internacional do trabalho com a hierarquia étnico-racial global e com a inscrição de migrantes do Terceiro Mundo na hierarquia étnicoracial das cidades metropolitanas globais. (GROSFOGUEL, 2008, p. 126).

Entretanto, estamos passando por uma transição de uma "velha" ordem mundial, para uma "nova" ordem mundial. Transição que é oriunda de uma onda civilizacional, na qual suas normas paradigmáticas são impostas estabelecendo novas ofertas, normas, valores que se adéquam à lógica hegemônica vigente. Carregando privilégios sincrônicos e diacrônicos, que a partir de determinada temporalidade, evocam essências e leis naturais produtoras de uma política internacional que tem como objetivo predeterminar geograficamente as entidades 
e as visões territoriais estatais de dominação do espaço global, para assim fortalecer a idealização singular do mundo imposta pelo significado ontológico do ano de 1492 (Ó TUATHAIL, 1997).

Dessa maneira, como destacado por Ivaldo Lima (2013), ao se pensar uma alternativa crítica para a construção do conhecimento geográfico, podemos analisar as formas pelas quais os atores políticos entendem e praticam a política em termos espaciais. Situando-os no centro dos debates e práticas geopolíticas, para então desconstruir os discursos de poder institucionalizados que venham a justificar as políticas de poder.

Essa alternativa pode ser entendida como contranarrativa, na qual como destacado por Sassen (2003) apud Lima (2013), tem como objetivo buscar modalidades de representação e práticas geopolíticas que permitam a aplicação de uma imaginação geográfica construtora de novas espacialidades do político que venham a

descolonizar o discurso geopolítico do ponto de vista hegemônico, numa busca por novos olhares [...] desloca o centro das atenções do Estado territorial para outras formas de entidades políticas como os movimentos sociais, grupos anticoloniais e ativistas antiglobalização. (LIMA, 2013, p. 156).

Uma dessas buscas pode ser dadas, segundo Ó Tuathail e Dalby (2002), através de uma geopolítica imaginária, ou seja, uma geopolítica que projeta um espaço com formas cartográficas que territorializam lugares, fundando e construindo sociedades guiadas por lutas multiculturais de representação de lembrança da história, que evocam fronteiras totalizantes e conceituais perturbadoras de manobras ideológicas, que descrevem tradições geográficas; encarando-as como conjunto de práticas espaciais, materiais e representacionais fundamentadas em mitologias culturais e particulares. Dessa maneira, segundo os autores, há de se ter em mente que cada lugar possui uma especificidade geográfica imersa em significados que a definem e informam entendimentos geográficos acerca do mundo que envolve o cotidiano e a prática política.

Ao propor a descolonização do saber geográfico proporciona-se a produção e ruptura de epistemologias geográfica a fim de garantir novas interpretações e formas de viver o lugar, por meio das variadas existências, múltiplas vozes, temporalidades e histórias, bem como representações e narrativas capazes de 
romper com o conhecimento geográfico moderno imposto pelo significado ontológico do ano de 1492

Esta superação do conhecimento para Dussel (2016), proporcionará a compreensão do mundo - através de um constante processo dialético que ultrapassa seus limites e se manifestando através da exterioridade, ou seja, um discurso filosófico construído pela periferia e oprimidos manifestadores de fenômenos que estabelecem mundos, que segundo Aníbal Quijano (2010), se realizam historicamente de forma a construir um modo de existência social, possuidor de um horizonte próprio, específico e alternativo.

Realização que segundo o autor, é dada através de uma nova interpretação da modernidade trazendo elementos incorporados que expõem a exterioridades situadas para além da modernidade como processos de "mútuo enriquecimento filosófico, que exige se situar eticamente, reconhecendo todas as comunidades filosóficas de outras tradições com iguais direitos de argumentação”. (DUSSEL, 2016, p. 173). Logo, não podemos esquecer de destacar nesse processo a "relação entre cultura popular e política, em diversas escalas espaciais" (DOODS, 2010, p. 114). Cujo, suas imagens são constantemente usadas "para ilustrar uma análise geral ou usadas ocasionalmente para esclarecer questões específicas" (DOODS, 2002, p. 171), construindo um conhecimento geopolítico que há de ser "uma forma de análise, [...] sensível ao contexto autoral e ao impacto do público, em vez de apenas mais um ato privilegiado de interpretação acadêmica". (DOODS, 2002, p. 194).

Ao considerar a importância da relação entre cultura popular6 e política na construção do conhecimento geopolítico crítico, nos inserimos em um subconjunto da mesma denominado geopolítica popular7. Esta forma de se pensar

\footnotetext{
6 Entendendo a abrangência de significados que envolvem o conceito de cultura popular, se vê necessário apresentá-lo de forma a não fugir do objetivo da dissertação. Posto isso, podemos compreendê-la como "aquilo que é elaborado pelas classes populares e, em particular pela classe trabalhadora, segundo o que se faz no polo da dominação, ou seja, como repetição ou como contestação, dependendo das condições históricas e das formas de organização populares". (CHAUÍ, 2008, p. 59).

7 Por entender que a geopolítica popular é um subconjunto da geopolítica crítica, se vê necessário expor os outros subconjuntos que também fazem parte da perspectiva da geopolítica crítica. O primeiro, Geopolítica Formal, tem seu conhecimento sendo produzido por "visões e doutrinas de comportamento geopolítico produzidas por "intelectuais do Estado", organizados em comunidades estatais ou interestatais [...] corpos acadêmicos universitários etc" (PRECIADO CORONADO, 2010, p. 71). Por sua vez, a Geopolítica Prática, "se refere as narrativas, discursos políticos, e práticas diplomáticas exercidas por líderes de Estado no exercício e ação da política exterior [...] determinando os distintos códigos geopolíticos que estruturam o sistema internacional". (PRECIADO CORONADO, 2010, p. 71). Assim sendo, a tipologia formal que
} 
o discurso geopolítico considera "a maneira pela qual as representações da política mundial circulam na cultura popular". (DOODS, 2010, p. 114), desenvolvendo "uma geopolítica com um discurso localizado dentro de um nexo de poder e conhecimento". (DOODS, 2010, p. 114), que permite encarar filmes, histórias em quadrinhos como fontes interpretativas de "representações geográficas e entendimentos da política mundial” (DOODS, 2010, p. 114-115).

No qual as interpretações buscam destacar não só "a importância da dimensão cultural popular para a política, mas também contribui para um projeto mais amplo, que considera as relações entre poder, representação e público". (DOODS, 2010, p. 116).

Entretanto, é importante destacar que não devemos limitar a contribuição da geopolítica popular no que considera a mídia como forma de entender discursos e projetos de grupos hegemônicos da sociedade, mas é "necessário considerar uma variedade de formatos populares - filmes, histórias em quadrinhos e jornais [...] ao analisar a formação da reprodução dessas culturas geopolíticas". (HOLLAND, 2012, p. 107-108).

Ao considerar as histórias em quadrinhos como um discurso geopolítico popular construído através da ideia de contranarrativas, debatidas em parágrafos anteriores, assume-se a existência de um conhecimento anti-geopolítico que "perturba as narrativas dominantes que justificam visões hegemônicas e suas políticas resultantes. [...]desafia leitores e telespectadores a reconsiderar o script dominante de eventos geopolíticos" (HOLLAND, 2012, p. 108).

Diante disso, ao considerar também a perspectiva antigeopolítica como uma forma de se pensar a geopolítica popular; defende-se "o reconhecimento não apenas da visualidade da hegemonia, mas também da visualidade da resistência". (HOLLAND, 2012, p. 108). Reconhecimento que expõe "uma espécie de geopolítica cotidiana que está presente em uma variedade de mídias". (HOLLAND, 2012, p. 109). Entendida “como a imaginação geopolítica é

distingue a geopolítica popular para as demais formas críticas de se pensar a geopolítica, é o fato de que a mesma busca, através da mídia entender como determinado discurso e prática política perpetua "através de determinado coletivo nacional e transnacional". (Ó TUATHAIL, 1999, p. 110). Permitindo enxergar os discursos geopolíticos de forma inseparável de "representações e práticas geopolíticas". (CAIRO, 2008, p. 203). Representações que "implicam signos, códigos e "entendimentos" que são necessários para fazer inteligíveis as práticas espaciais" (CAIRO, 2008, p. 203), que por sua vez "se referem a lugares específicos e a conjuntos espaciais interrelacionados e organizados para a produção econômica e a reprodução social em uma dada formação social". (CAIRO, 2008, p. 203). 
constituída como discursos do cotidiano por meio de uma variedade de formas visuais e textuais". (HOLLAND, 2012. p. 111).

Como forma de mostrar como podemos usar a perspectiva da geopolítica popular relacionada ao Giro Decolonial a fim de superar o conhecimento geográfico imposto pelo significado ontológico do ano de 1492, iremos através da exposição de duas histórias em quadrinhos mostrar contra narrativas que "influenciam a percepção geopolítica [...] com formatos de resistências". (HOLLAND, 2012, p. 111-112). Construindo "visões alternativas da geopolítica". (HOLLAND, 2012, p. 125), através de "novas" palavras que venham "reinterpretar a palavra do mito e a escrita da Terra, de maneira que essa "escrita" possa comportar uma leitura nova". (DARDEL, 2015, p. 65).

É importante destacar que antes mesmo da primeira história em quadrinhos ser elaborada, o ato de contar histórias já acompanha os grupos sociais desde a Antiguidade, as histórias são elaboradas com objetivo de destacar determinado comportamento de certa comunidade, dramatizando relações sociais e problemas do cotidiano (EISNER, 2005). Isto posto, ao se examinar uma história em quadrinhos há uma comunicação, “'numa "linguagem” que se vale da experiência visual comum ao criador e ao público". (EISNER, 1999, p. 7). Esta experiência visual é dada de maneira artística e literária através da "disposição de figuras ou imagens e palavras para narrar uma história ou dramatizar uma ideia". (EISNER, 1999, p. 7). Trazendo em sua estrutura uma "contenção de pensamentos, ideias, ações, lugar ou locação". (EISNER, 1999, p. 38), que permite - segundo o autor expressar determinado período de tempo através de cenas e atos.

Ao ser habilidosamente retratada, a imagem das histórias em quadrinhos "consegue deflagrar uma lembrança que evoca o reconhecimento e os efeitos colaterais sobre a emoção". (EISNER, 1999, p. 100) fazendo por sua vez, com que seus símbolos sejam construídos a partir da experiência, ou seja, a partir do "emprego imaginativo do conhecimento ${ }^{8}[\ldots]$ assim como da habilidade de retratar ou caricaturar e manejar as ferramentas do desenho". (EISNER, 1999, p. 144).

Destarte como destacado por Mc Cloud (1995), a forma de retratar determinada Cosmovisão através das histórias em quadrinhos faz com que esteja relacionada a ideias e imagens diversas, explicitadas através de determinado

8 Este emprego imaginativo do conhecimento, como já destacado, cria um mundo que é oriundo de um "projeto intelectual-imaginativo". (TUAN, 1990, p. 444). 
conteúdo. Esse processo, para o autor depende de forma direta de um criador que percebe e mede o tempo através de uma experiência que permite não apenas criar a história em quadrinhos, mas fazer com que o público em geral lide com a “prática concreta do viver”. (EISNER, 1999, p. 25).

Prática que é uma habilidade de expressão que "nos torna capazes de reconhecer e de compartilhar emocionalmente a surpresa, o humor, o terror e todo o âmbito da experiência humana". (EISNER, 1999, p. 25). Evocando reconhecimentos e criações que são retratados de acordo com um "propósito que esteja de acordo com o plano narrativo do autor" (EISNER, 1999, p. 89). Tornando assim, o conhecimento produzido pelas histórias em quadrinhos uma “memória comum da experiência”. (EISNER, 1999, p. 100).

Conhecimento que se encontra diretamente associado a comportamentos sociais e valores morais de determinado grupo social, e, é apresentado através de uma sequência de eventos que retratam, representam, recriam, ressignificam ideias conhecidas ou não (EISNER, 2005). Empregando um código visual ${ }^{9}$, que representa imagens que formam uma "narrativa baseada na coesão, orientando imagens isoladas em um processo de transformação”. (POSTEMA, 2018).

Para assim criar "um sentido a partir das sequências que se aproxima da narrativa". (POSTEMA, 2018). Envolvido por inúmeros códigos e signos diferenciados que possuem seus particulares níveis de significação e decodificação, que por sua vez, são constituídos por signos visuais dos mais variados (POSTEMA, 2018).

Assim, é importante destacar que:

As funções de significação nos quadrinhos não são baseadas apenas nos signos presentes como o conteúdo do quadro, e sim fortemente regidas pela maneira como os quadros são organizados na página e como, se for o caso, que eles são emoldurados. (POSTEMA, 2018, p. 60).

Isto é, as histórias em quadrinhos geram eventos oriundos predominantemente de imagens, sendo o texto presente nelas uma forma de criar determinada especificidade que é dada pelo autor da história em quadrinhos (POSTEMA, 2018, p. 123). Esta especificidade por parte do leitor é carregada de “conhecimento de ações, causalidade, para preencher temporariamente as lacunas,

9 Código visual que exige do leitor uma pré-disposição "a reelaborar os fragmentos que recebe. Ainda que, eventualmente possa não estar plenamente consciente disso". (POSTEMA, 2018, p. 6). 
de forma hermenêutica, em que é necessário adaptá-las como informações novas que se tornam disponíveis na narrativa". (POSTEMA, 2018, p. 147).

Para assim transmitir uma ideologia que desperta no leitor inúmeros tipos de sentimentos que são orientados e significados por um conteúdo ideológico que orienta e significa a interpretação. Tal condição é dada pela capacidade de criarmos e recriarmos símbolos desenvolvidos através de práticas cotidianas que permitem a compreensão acerca da realidade que nos circunda (TOLEDO, 2011). Assim sendo, a percepção acerca do mundo construído através das histórias em quadrinhos, se encontra diretamente relacionadas ao mundo que nos circunda através de, um processo seletivo que se encontra inserido em um processo no qual a realidade é construída através de "um processo mental ativo, em que nos utilizamos de um leque de informações coletadas e inferidas". (RIO, 1995, p. 94).

No entanto, este processo de integração entre a visão de mundo e realidade proporcionado pelas histórias em quadrinhos, estão imersos em relações de poder, que transmitem para o leitor uma visão acerca de determinado evento histórico ou realidade. Estas relações como já visto, são hierarquizadas verticalmente, de modo a impor uma realidade opressora através, por exemplo, de narrativas construídas a partir das histórias em quadrinhos. Como exemplo desta imposição, temos as histórias criadas por Wall Disney que são:

criações e símbolos se transformaram numa reserva inquestionável do acervo cultural do homem contemporâneo: os personagens têm sido incorporados em cada lugar, colados nas paredes, acolhidos em plásticos e almofadas e, por sua vez, têm retribuído convidando os seres humanos a pertencer à grande família universal Disney, além das fronteiras e das ideologias à grande família universal Disney, além das fronteiras e das ideologias, aquém dos ódios e das diferenças dos dialetos. (DORFMAN; MATTELART, 2010, p. 14).

Em vista disso, um dos personagens de Walt Disney é o Tio Patinhas. Este personagem como é sabido, é dono de uma fortuna imensurável, e, percorre o mundo desbravando lugares até então desconhecidos pela sociedade moderna. Esse ímpeto de carregar consigo o espírito da luz civilizacional, se encontra inserido nas ideais que estruturam o significado ontológico de 1492, pois, ao levar luz a estas partes do mundo, Tio Patinhas, se relaciona com o outro não-moderno, estabelecendo relações que reproduzem desigualdades sociais presentes no mundo moderno. 


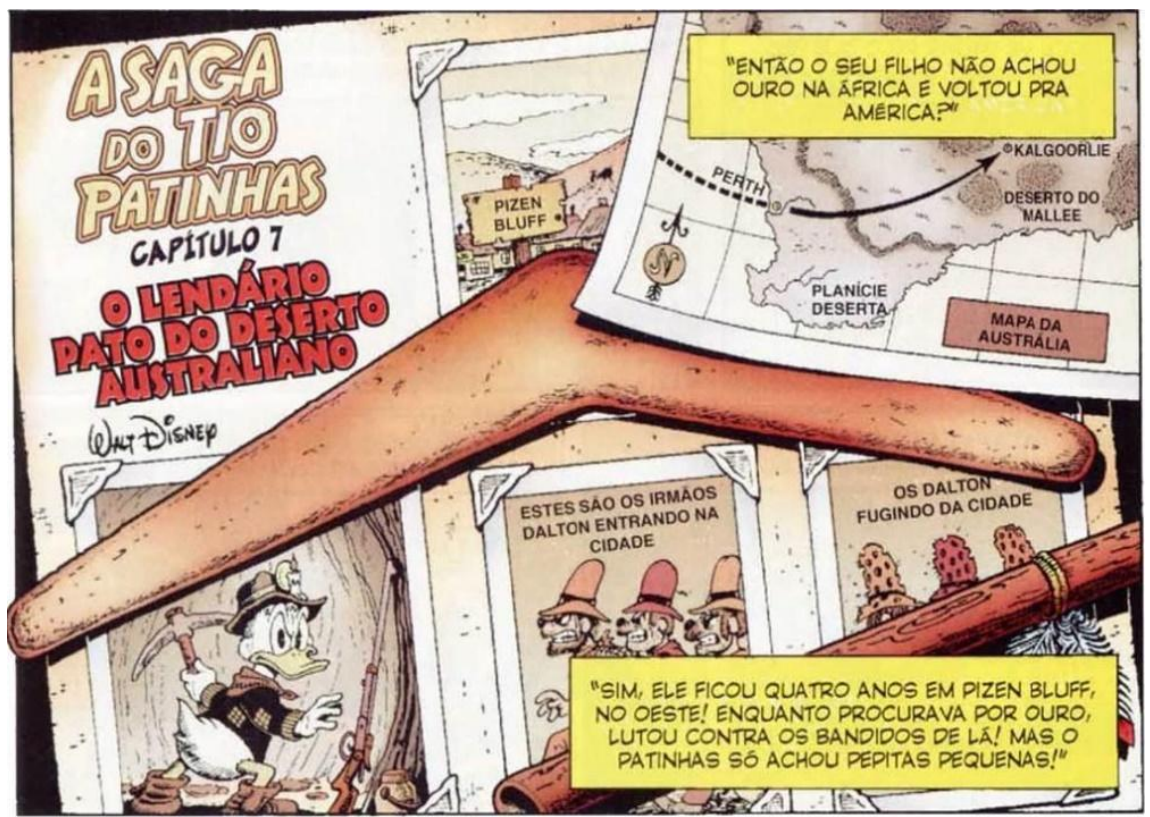

Como exemplo, temos a história em quadrinhos "Febre do Ouro" (2014). No qual o mundo descrito nesta história é construído - segundo Ariel Dorfman e Armand Mattelart (2010) - através de uma visão de mundo que permite a perpetuação das relações de poder existentes no sistema do mundo atual. Calcada em representações imersas no significado ontológico do ano de 1492 que formam um "ideal ético e estético que lhes parece como o único projeto possível de humanidade" (DORFMAN; MATTELART, 2010, p. 19-20).

A fim de se isentar de um compromisso para com a sociedade, nem sempre os lugares das histórias em quadrinhos Disney são reais. Como exemplo da história citada, que cria um lugar chamado Desertistão, e, como pode ser visto através da Figura 1, outros elementos contribuem para esta perpetuação.

Como as vestimentas usadas pelos habitantes desta remota região, as técnicas estereotipadas que conduzem o leitor a imaginar sua localização no Oriente Médio, e, que contrasta com o avião que transporta o Tio Patinhas e seu ideal de homem moderno passando no canto superior à direita, e a reação dos habitantes no canto superior à direita espantados ao ver o "pássaro de ferro" sobrevoando suas cabeças. 


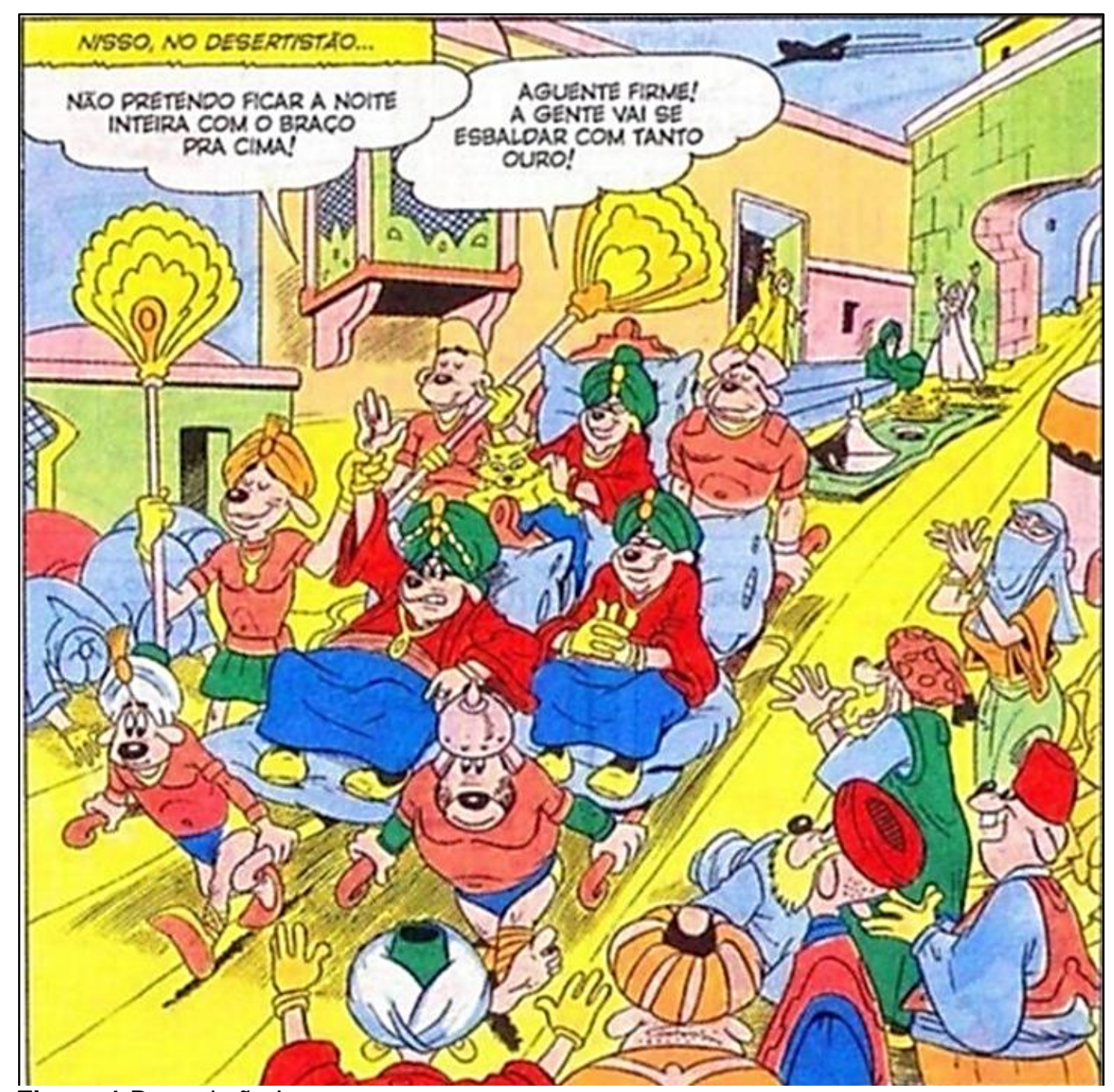

Figura 1 Desertistão I

Fonte: Febre do ouro

Cabe destacar que, por mais que se crie a separação do mundo entre mágico e real, as relações de poder hegemônicas de opressão, ou seja, a colonialidade, são explicitamente expressas através da posição que cada personagem ocupa no espaço Disney

Todo personagem está de um lado ou de outro da linha demarcatória do poder. Os que estão abaixo devem ser obedientes, submissos, disciplinados, e aceitar com respeito e humildade as ordens superiores. Os que estão acima exercem, em troca, a coerção constante: ameaças, repressão física e moral, domínio econômico (...) É um mundo de permanentes privilégios e benefícios (...) O mundo Disney é um orfanato do século XIX (...) Apesar de seus inumeráveis deslocamentos geográficos, viagens a todos os continentes, febril mobilidade enlouquecida, os personagens contêm-se invariavelmente - voltam - sempre nas mesmas estruturas de poder. (DOFRMAN; MATTELART, 2010, p. 32). 
Estas relações demarcatórias de poder podem ser identificadas noutro trecho da história (Figura 2) quando Tio Patinhas descobre que os Irmãos Metralha, haviam falsificado um símbolo que lhe dava direito à uma fortuna oferecida pelo governante do Desertistão.

O outro ponto a destacar, é a forma como o povo do Desertistão reage frente quando Tio Patinhas tenta desmascarar os Irmãos Metralha. O personagem é levado pelos mesmos de forma "selvagem", indicando mais uma vez a subordinação ao outro moderno.

Esta subordinação também pode ser entendida através dos elementos que representam o nível de desenvolvimento da sociedade do Desertistão, a exemplo das cenas (Figura 1) em que os Irmãos Metralha são carregados em uma espécie de liteira (contrastando com a presença de um meio de transporte moderno) e, (Figura 2) em que se destaca um cidadão do Desertistão portando uma , clava de madeira.

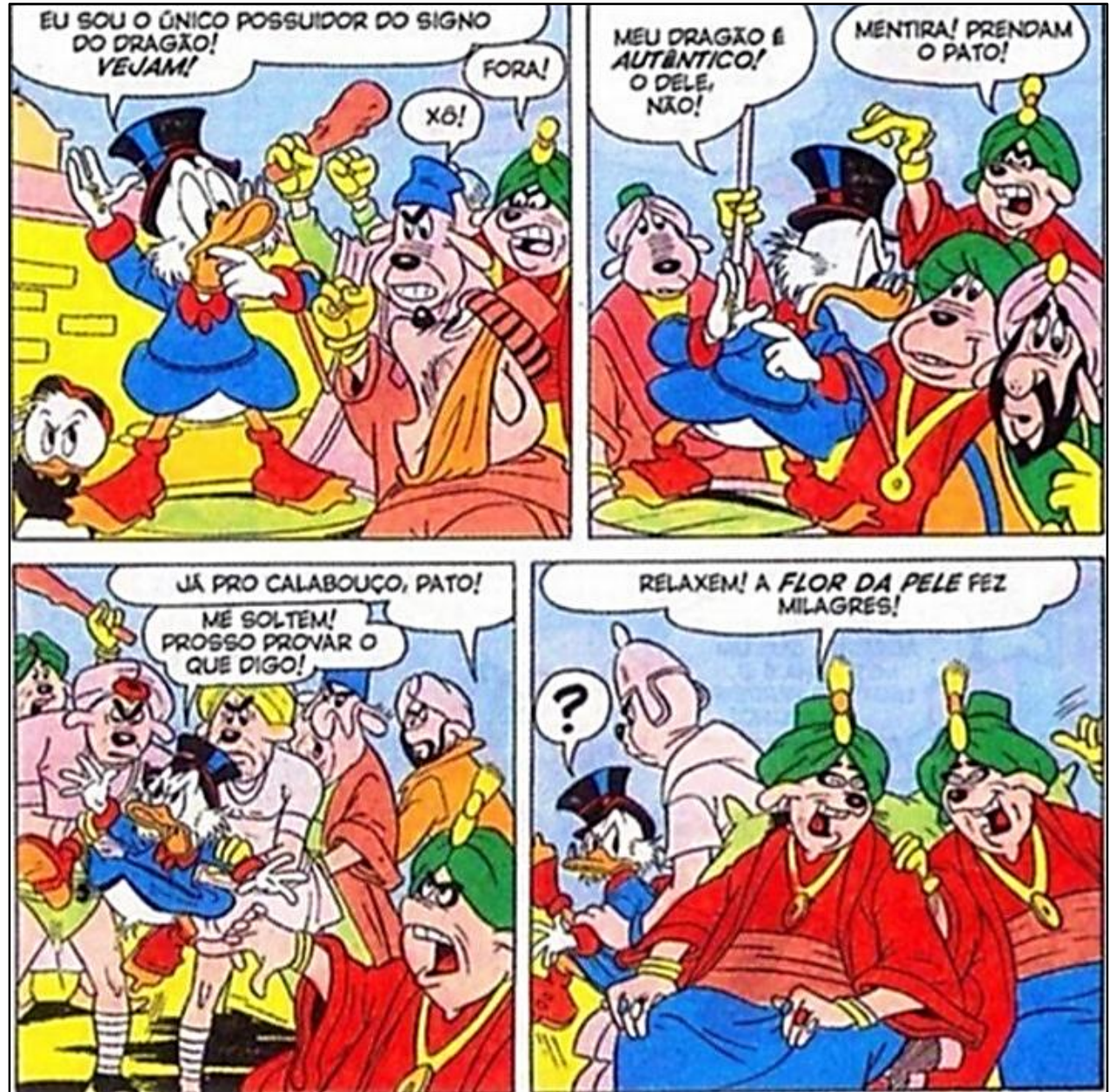

Figura 2 Desertistão II 
Desta forma quando analisado pela ótica da geopolítica popular e decolonialidade, o personagem Tio Patinhasse apresenta como um dos principais sujeitos e agentes para a perpetuação e naturalização das colonialidades debatidas no primeiro capítulo, pois, suas respectivas identificações são dadas por estereótipos como bárbaro/civilizado, bom selvagem/mal selvagem (DORFMAN; MATTELART, 201).

A naturalização do discurso associado ao significado ontológico do ano de 1492 expresso na história analisada é expressa através das relações sociais, que segundo os autores, são mediadas pela aceitação da autoridade sobre o outro. $\mathrm{Na}$ Figura 1, podemos ver essa aceitação na feição dos habitantes do Desertistão que carregam os Irmãos Metralha.

À vista disso a imposição de um imaginário de quem lê as histórias em quadrinhos da Disney faz com que o conhecimento e a visão de mundo construídos por cada indivíduo, mesmo que acompanhe suas respectivas experiências para com o espaço no qual está inserido, esteja diretamente associado ao mundo criado pelas histórias em quadrinhos da Disney, que, como visto, são uma maneira de colonizar "o mundo diário ao alcance do homem e seus problemas comuns" (DORFMAN; MATTELART, 2010, p. 143).

Entretanto, não são as histórias em quadrinhos elaboradas pela Disney, como também pela DC Comics e Marvel, além de outras, que também trazem consigo um conhecimento construído através de um grupo social que é dono "dos meios de produzir a vida [...] as ideias, os sentimentos, as intuições, numa palavra, o sentido do mundo". (DOFRMAN; MATTELART, 2010, p. 154).

Logo, ao assumir a importância dos elementos que compõem as histórias em quadrinhos e dos personagens na construção do significado construído por cada uma, pode-se afirmar que os elementos presentes nas histórias em quadrinhos "são os grandes responsáveis por cativar o leitor e, com isso, comunicar eficazmente [...] ]entre os quadrinhos e na confiança na carga cultural do leitor". (PRESSER; SCHLÖGL, 2013, p. 17).

Esta capacidade de (re)criar mundos através de símbolos e diferentes significados, nos leva a questionamentos acerca da importância das histórias em quadrinhos como um objeto geográfico na análise socioespacial, pois, cria ações sequenciais inseridas no tempo e espaço que são, que são formadas por movimentos que ganham vida através da inter-relação entre a leitura das 
sequências de imagens e a compreensão da narrativa. Inter-relação como visto nos parágrafos anteriores, é mediada por elementos e personagens que estruturam cada história em quadrinhos de forma a representar certa coerência e sentido do lugar representado pela mesma (GOMES; GÓIS, 2008).

Como exemplo desta forma de representação iremos usar o episódio áudio visual da Turma da Mônica "O cabelo"10 . importante destacar que o uso do áudio visual através de uma história em quadrinhos, considera sua "transformação cultural à medida que os consumidores são incentivados a procurar novas formas de se comunicar". (NICOLAU; MAGALHÃES, 2013, p. 63). Ao se aceitar essas novas comunicações, se criam possibilidades para "novas formas de ação e interação no mundo social, novos tipos de relações e novas maneiras de relacionamento do indivíduo com o outro e consigo mesmo". (NICOLAU; MAGALHÃES, 2013, p. 69).

Isso posto, através da animação, buscaremos - através da geopolítica popular e da decolonialidade - expor momentos em imagens para poder mostrar como as histórias em quadrinhos são capazes de criar representações e relações de poder, que por mais que estejam em um plano para além do real, são muitas vezes reflexos do mesmo e possibilitam seu uso como um objeto da análise socioespacial pela geografia.

No episódio analisado, iremos destacar a transição do cabelo da Mônica. Tudo começa com o Franjinha inventando um tônico capilar capaz de dar o cabelo ideal a quem o usasse. Como cobaia, Mônica, se propõe a usar. Representando um processo de transição, como pode ser visto na sequência de imagens a seguir, do feio para o belo, o cabelo da Mônica antes pequeno e liso, primeiro torna-se crespo para assim se tornar um belo cabelo brilhoso ondulado claro (Figura 3).

\footnotetext{
${ }^{10}$ SOUZA, Maurício. 0 cabelo. $2015 . \quad$ (58s). Disponível em: https://www.youtube.com/watch?v=amegjq8nlAw>. Acesso em : 20 mai. 2020.
} 


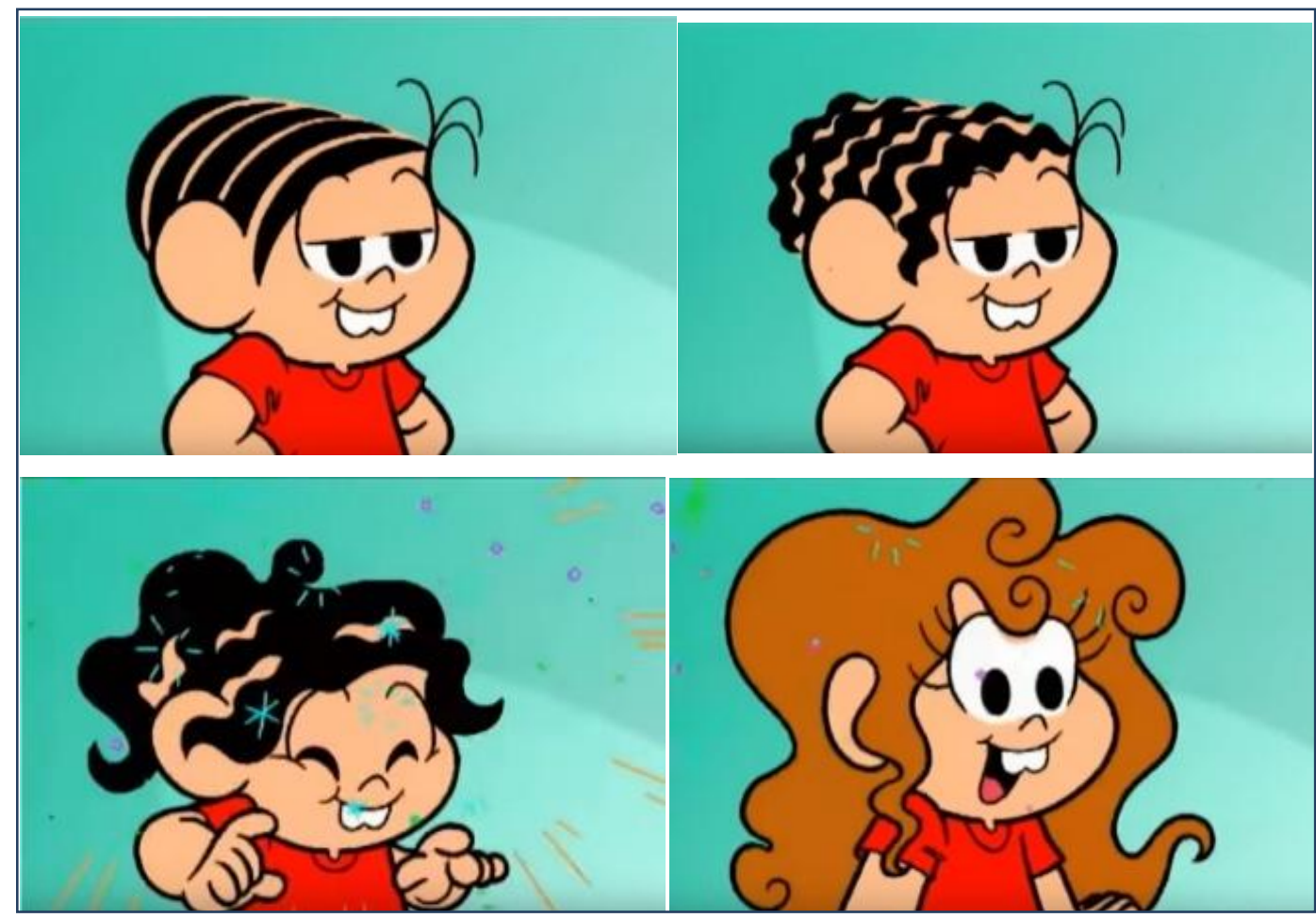

Figura 3 Transição

Destarte, como analisado nos trechos da história em quadrinho de Walt Disney da Turma da Mônica, as mesmas usadas como um objeto para análise socioespacial pela geografia são produtoras de sequência de visões de mundo (MENDONÇA e REIS, 2016), no qual cada indivíduo possui uma posição neste espaço, o que faz com que expressem determinada organização espacial, que é dada por $n$ tipos de percepções reveladoras de um cenário geográfico. Diante disso, as histórias em quadrinhos revelam espaços que são habitados "por personagens que transparecem [...] cenários de grande profundidade visual e expressam significados" (MENDONÇA; REIS, 2016, p. 56). Fazendo, assim, com que se permita "notar objetos e seus significados que remetem uma síntese espacial dos lugares representados, sejam eles ficcionais ou não.” (MENDONÇA; REIS, 2016, p. 56).

Representar das mais variadas formas o espaço geográfico, permite que se (re)construam significados diversos que venham a revelar cenários e ações que venham a (re)significar os lugares representados através da perspectiva de cada indivíduo (MENDONÇA; REIS, 2016). 
Por conseguinte, é importante destacar que:

Ao se tratar de uma percepção do espaço por meio dos quadrinhos, essas representações que recriam o cenário geográfico são considerados [...] Representações, antes de qualquer coisa, expressam escolhas de princípios, de significação própria. (MENDONÇA; REIS, 2016, p. 57-58).

Fazendo assim, para Mendonça e Reis (2016), com que as histórias em quadrinhos possuam um universo paralelo capaz de oferecer representações que auxiliam na construção de significados valorizados por certo tipo de conhecimento, que como visto, é dado pela Cosmovisão de quem a constrói. Como também, são capazes de romper com o cotidiano "trazendo novas formas de relações para com um espaço, criando um novo sentido para o mesmo, como também uma lógica para o uso de seus objetos" (MENDONÇA; REIS, 2016, p. $58)$.

Estas novas formas de relações, de acordo com os autores, fazem com que as histórias em quadrinhos concebam o espaço como uma dimensão da ação social, e, estruturem através das mesmas diferentes temporalidades que "requerem do leitor arranjos na montagem para reconstruir a narrativa.” (MENDONÇA; REIS, 2016, p. 61).

Ao conceber o espaço como uma dimensão da ação social, também se produz de maneira concomitante, imagens e narrativas que servem de “instrumentos tanto de percepção como de compreensão do mundo em uma visão tridimensional, e não apenas como ilustrações." (MENDONÇA; REIS, 2016, p. 64). Isto posto, as histórias em quadrinhos são aqui entendidas como um meio de comunicação que está inserido no processo de transformação da sociedadeNo qual carrega consigo um ponto de vista permeado de símbolos e significados que estão para além do que é dado, estando sempre carregados de um conhecimento científico. Entretanto, por mais que seus significados estejam diretamente relacionados à visão de mundo e à experiência de quem as produziu, se encontram também diretamente associados à perspectiva de quem lê a história em quadrinhos.

Ao significar as imagens das histórias em quadrinhos através da percepção, possibilita-se a (re)construção e (re)interpretação do espaço geográfico como também das relações de poder nele existentes. Não se limitando assim a visão de mundo imposta pelo significado ontológico do ano de 1492, pois, também se 
encontra presente em contranarrativas, que como visto, são responsáveis por criar perspectivas acerca da realidade e do conhecimento que estão para além da visão de mundo imposta pela inter-relação das colonialidades debatidas ao longo do primeiro capítulo. Como exemplo temos a história em quadrinhos "Eles nos chamavam de inimigo" com o roteiro do artista George Takei.

Esta história busca mostrar o tratamento que os nipo-americanos, residentes nos Estados Unidos, sofreram após o bombardeio a Pearl Arbor, por meio da narrativa de George Takei. No qual, através do diálogo com os traços marcantes de Harmony Becker, busca-se mostrar como o sofrimento deste grupo social, é tão digno quanto o sofrimento de outros grupos oprimidos ao longo da segunda guerra mundial.

Um exemplo a destacar desta opressão fora os decretos civis do ano de 1942, que "mapeava um distrito e ordenava que todos os nipo-americanos ali residentes se dirigissem a um ponto de referência para tramitação e remoção". (TAKEI, 2019, p. 23). A maneira que esses campos se encontravam dispostos no território americano pode ser vista através da figura 4, e, que eram habitações em condições precárias. Um exemplo desta precariedade eram as condições dos barracões, no qual "nunca vou esquecer do calor que saiu daquela cabana assim que papai abriu a porta". (TAKEI, 2019, p. 2019).

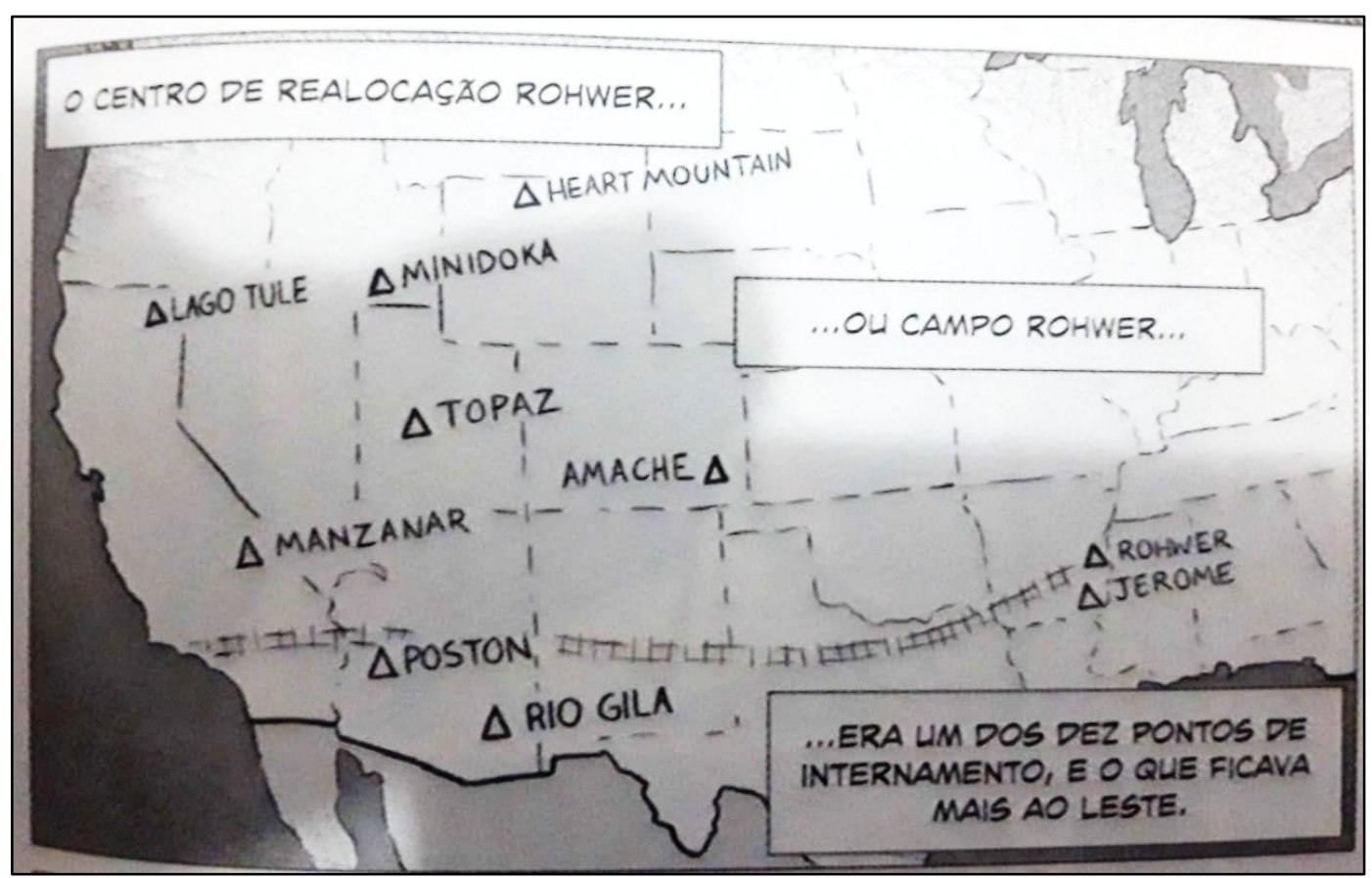

Figura 4 Localização dos pontos de internamento de nipo americanos Fonte: TAKEI, George, 2019, p. 55. 
Os campos de internamento, como pode ser visto na Figura 5, eram organizados de forma a alojar 8 mil famílias de nipo-americanos em um "campo que ficava onde antes era um pântano e quando chegavam as chuvas, elas vinham com força”. (TAKEI, 2019, p. 77). Entretanto, as condições climáticas não impediam os nipo-americanos de ressignificarem o espaço que estavam inseridos. Um exemplo desta ressignificação, é exposto a partir da figura 6, quando "não sei de quem foi a ideia, mas não tardou para os homens saírem às vias, pregando restos de madeira para fazer uma passarela improvisada". (TAKEI, 2019, p. 77).

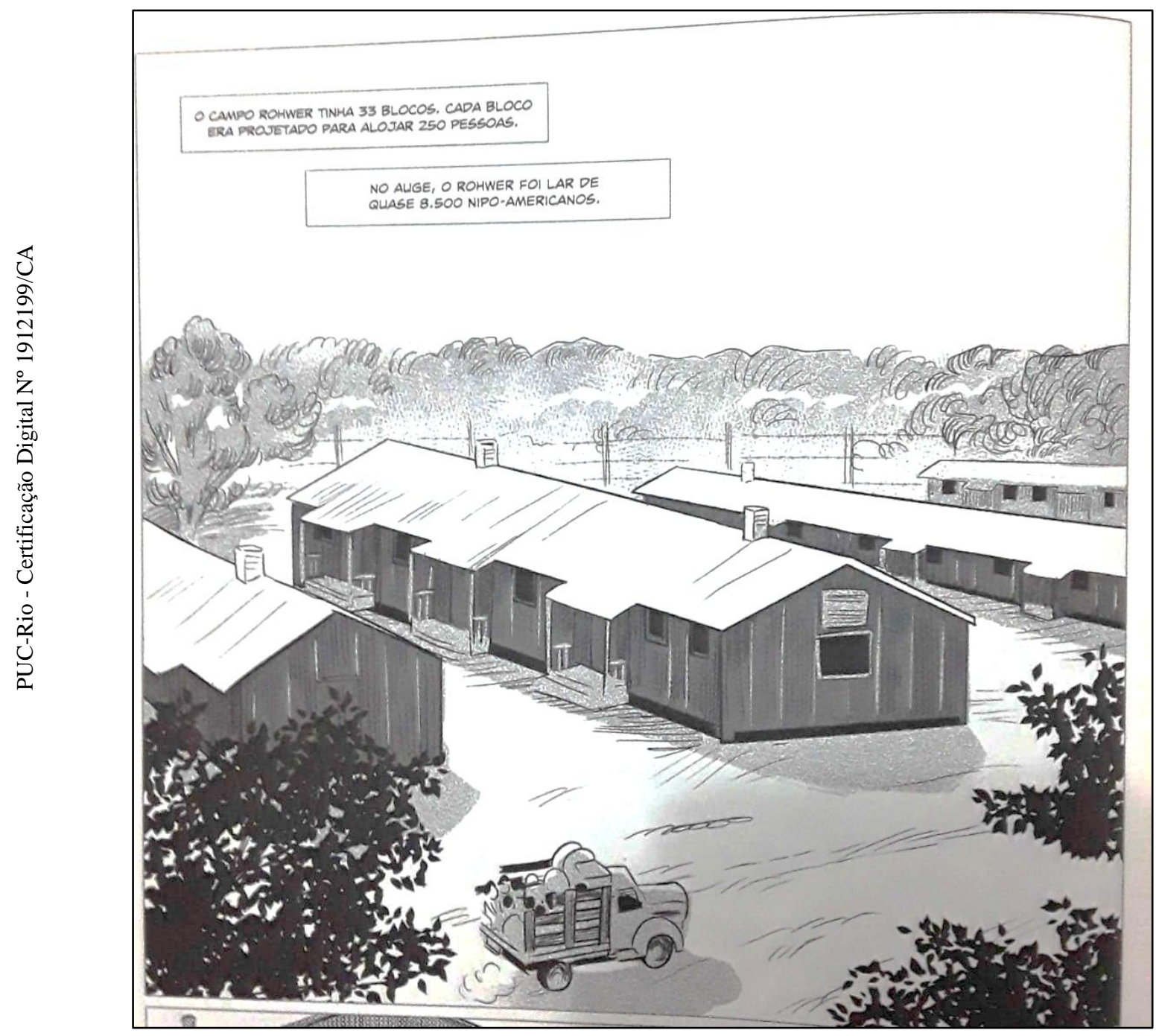

Figura 5 Campo Rohwer I

Fonte: TAKEI, George, 2019, p. 55. 

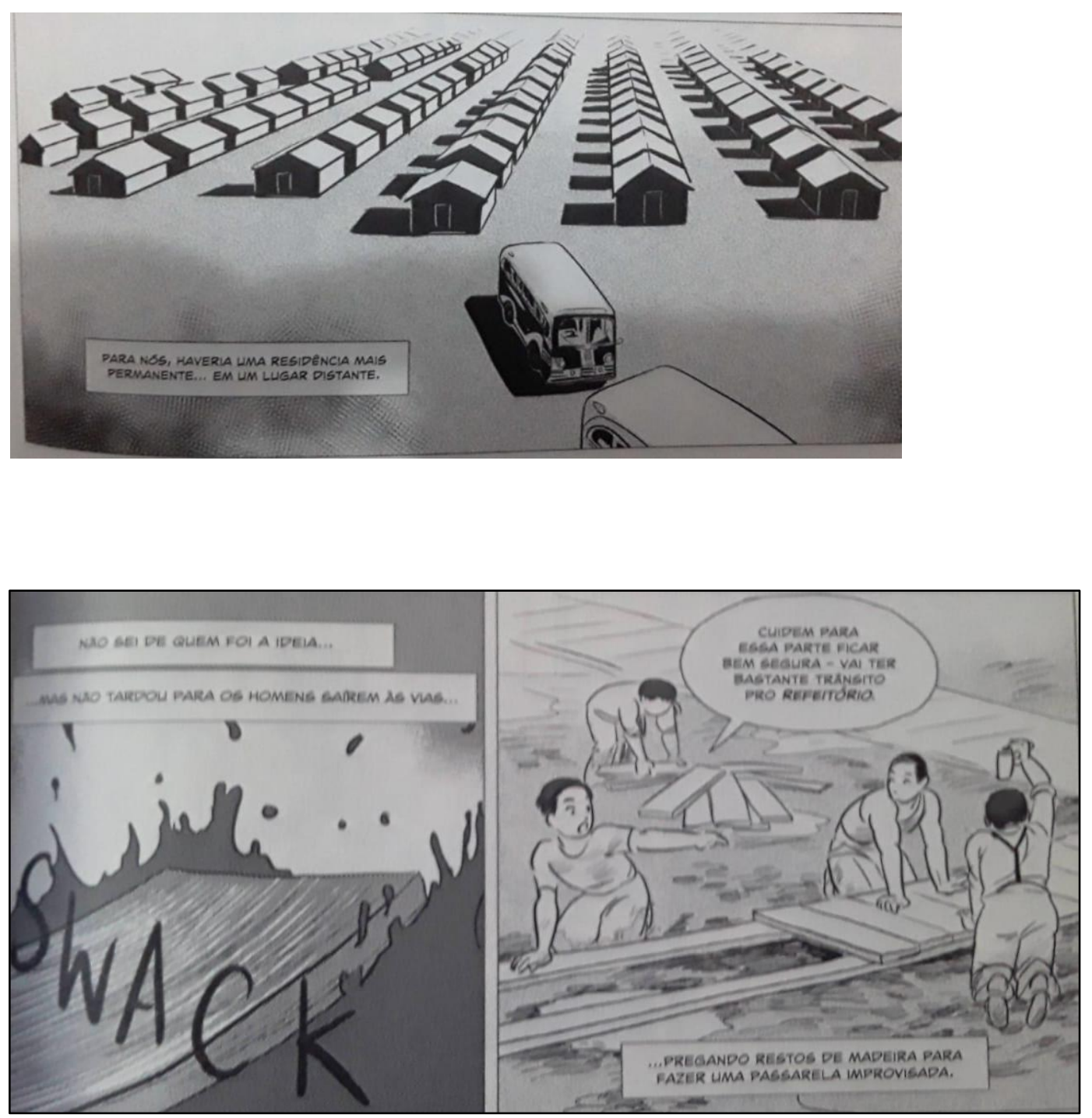

Figura 5 Tábuas

Fonte: TAKEI, George, 2019, p. 77.

Outro aspecto importante de ser destacado diz respeito à potencialidade dessa história em quadrinhos como uma forma de dialogar com a realidade dada através do diálogo entre a geopolítica popular e decolonialidade. Como exemplo temos a Figura 7, retratando quando George Takei, junto com sua família, ao embarcar no transporte que os levaria para os campos de internamento, recebe marcações que na história é muito bem destacada, a fim de mostrar a forma que os nipo-americanos eram tratados. Tratamento que afetava o campo subjetivo dos nipo-americanos, podendo ser sentido através da expressão facial dos pais de George Takei, como também pela sua fala ao afirmar: "para meus pais, era mais um ato desumano". (TAKEI, 2019, p. 36) 


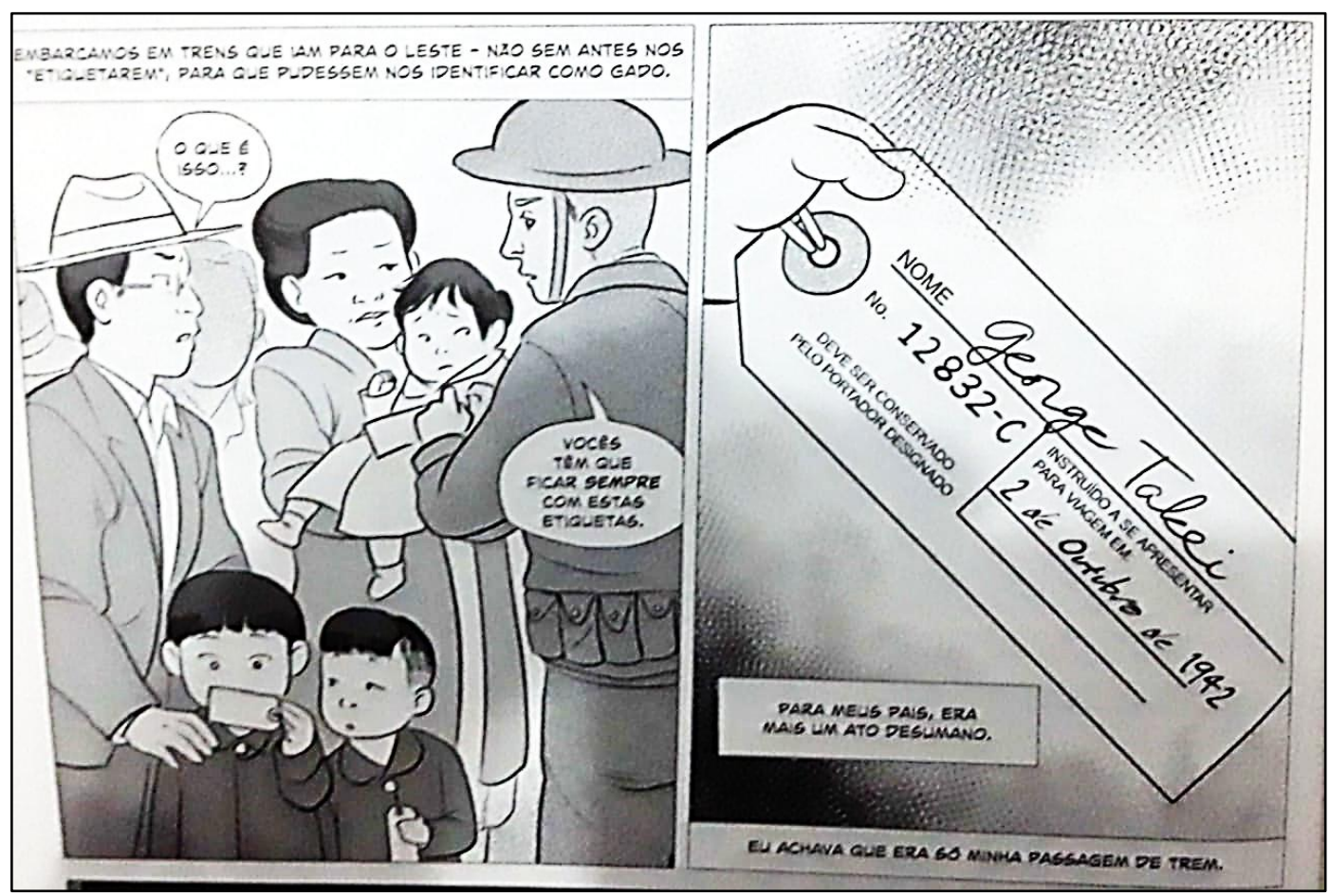

Figura 6 Mais um ato desumano

Mais um elemento que deve ser citado, que fortaleceu esta subalternização através da visão de mundo imposta pelo significado ontológico do ano de 1492, foi a elaboração de um questionário - por parte do governo estadunidense - que buscava avaliar a lealdade do povo nipo-americano para com os americanos, no qual qualquer resposta que fosse dada, seria usada de motivo para justificar "nosso cárcere injusto - como se eles tivessem direito de nos chamar de "inimigos estrangeiros" e nos prender desde o começo". (TAKEI, 2019, p. 115).

Assim, "Eles nos chamavam de inimigo" é um dos inúmeros exemplos de histórias em quadrinhos que podem ser considerados como contranarrativas decoloniais presentes na ideia de geopolítica popular, pois, tentam a partir de uma realidade e conhecimento dado, (re)interpretar a realidade através de uma perspectiva exterior para além do significado ontológico do ano de 1492.

No caso da história retratada neste capítulo, tirar o fardo histórico que os japoneses carregam após as explosões nucleares em seu território, que os põe como merecedores de tal ação, mostrando que para o pensamento moderno, violência é respondida com uma brutalidade sufocadora e excludente.

Posto isso, as histórias em quadrinhos quando analisadas pela ótica da geopolítica popular, através da inter-relação para com as ideias desenvolvidas pelo 
Giro Decolonial debatidas no primeiro capítulo, cria ações sequenciais inseridas em um tempo-espaço, que ganham vida através da inter-relação entre a leitura das sequências de imagens e a compreensão da narrativa, que juntas produzem significados de forma a representar o sentido de determinado lugar (GOMES; GÓIS, 2008).

Assim sendo, as histórias em quadrinhos revelam espaços "em que podemos notar objetos e seus significados que remetem uma síntese espacial dos lugares representados, sejam eles ficcionais ou não" (MENDONÇA; REIS, 2016, p.56). Permitindo assim, segundo os autores, que se reconstruam significados diversos reveladores de cenários e ações, que ressignificam lugares representados. Recriando o espaço geográfico como "cópias da realidade, uma vez que as representações não espelham o mundo, mas o criam [...] Representações, antes de qualquer coisa, expressam escolhas de princípios, de significação própria". (MENDONÇA; REIS, 2016, p. 57-58).

Representações que auxiliam na construção de significados que são capazes de romper com o cotidiano "trazendo novas formas de relações para com um espaço, criando um novo sentido para o mesmo, como também uma lógica para o uso de seus objetos" (MENDONÇA; REIS, 2016, p. 58). Novas formas de relação e sentido no espaço, que puderam ser vistas na história em quadrinhos "Eles nos chamavam de inimigos". Cujo através das narrativas de George Takei e arte de Harmony Becker, conceberam um espaço com uma dimensão que serve de instrumento "tanto de percepção como de compreensão do mundo em uma visão tridimensional, e não apenas como ilustrações” (MENDONÇA; REIS, 2016, p. 64). 


\section{3 \\ Aprendizagem significativa e conhecimento poderoso: um diálogo potente para o ensino de geografia decolonial}

Ao considerar o Giro Decolonial como uma contranarrativa potente reveladora de novas formas de pensar o conhecimento geográfico através do uso das histórias em quadrinhos pela perspectiva da Geopolítica Popular, considera-se a necessidade também de se pensar um ensino de geografia que esteja associado “a um novo tipo de imaginário universal [...] que descolonize as perspectivas [...] dos seus limites eurocêntricos". (GROSFOGUEL, 2008, p. 144).

A fazer esta conciliação, se permite ao estudante e professor, situarem-se no espaço em que estão inseridos a ponto de questionar-se acerca da posição que ocupam no mesmo. Revelando uma "estrutura intima do espaço tal qual nos aparece em nossas experiências concretas de mundo como membros de um grupo cultural”. (HOLZER, 2015, p. 143).

No qual, os elementos que o compõem, não podem ser reduzidos à objetivação da ciência, pois, agrupam "dimensões do conhecimento [...] sobretudo aquelas da ação e da afetividade". (BESSE, 2015, p. 114) que permitem que o conhecimento escolar de geografia seja experimentado através de $n$ dimensões que se relacionam intrinsecamente com o mundo vivido dando "a realidade geográfica um tipo de animação e de fisionomia em que ele revê sua experiência interior ou social”. (DARDEL, 2015, p. 6). Revisão que permite a apresentação e revelação de outras formas de experiências e relações de poder.

À vista disso, quando pensamos o conhecimento escolar de geografia através do Giro Decolonial e da Geopolítica Popular, assume-se a existência de saberes exteriores à escola que também imprimem grande influência na construção do conhecimento escolar. Portanto, como forma de romper com o conhecimento escolar de geografia imposto através da inter-relação das colonialidades abordadas no primeiro capítulo, buscamos neste capítulo uma aproximação entre conhecimento prévio e conhecimento especializado, para com a ideia de decolonialidade debatida no capítulo anterior. 
Ao reconhecer a importância deste diálogo para a construção do conhecimento escolar de geografia, reconhece-se que os conceitos trabalhados nas escolas pertencem a um mundo "construído por pesquisadores especialistas envolvidos em desenvolver conhecimento novo". (YOUNG, 2011, p. 616). No qual - segundo o autor - tem seus conteúdos estabelecidos por disciplinas ${ }^{11}$ e os diferentes tipos de currículo ${ }^{12}$.

Dessa maneira, a inter-relação entre o conhecimento prévio do estudante sobre o conhecimento escolar especializado da disciplina de geografia, revelará novas aproximações entre o cotidiano dos envolvidos no processo de ensinoaprendizagem a fim de construir um conhecimento escolar que revele "aspectos essenciais das relações sociais que se ocultam sob fenômenos que se mostram a nossa realidade imediata" (MALANCHEN, p. 131, 2018).

Logo, nesta parte do capítulo demostraremos a importância do conhecimento prévio e especializado para a formação de um conhecimento escolar que permita transformar a realidade dos envolvidos no processo de ensino e aprendizagem. Este debate se faz necessário porque, como Michael Young (2016) destaca, o conhecimento oriundo do cotidiano e da experiência não dá direito à liberdade de maneira isolada. É necessário também que haja uma interrelação, horizontal, não hierarquizada, em relação ao conhecimento produzido nas diferentes áreas da experiência humana. Assim, ao diferenciar o conhecimento prévio do especializado, busca-se expor suas respectivas potencialidades que fazem o estudante ir para além de sua experiência cotidiana (YOUNG, 2011).

A importância desta inter-relação é bem exemplificada por Young (2011), quando diz que através da geografia escolar ao abordar o tema "cidade" em sala de aula, até certo ponto será a mesma tanto para o professor quanto para o estudante. Entretanto sua relação não se dá da mesma forma, pois enquanto para o

\footnotetext{
${ }^{11}$ Disciplinas que para Young (2016), estão em constante movimentação. Cujo suas mudanças, são resultantes da atuação de especialistas, como também de pressões políticas externas e outras. O que faz para o autor com que os estudantes tenham acesso a um conhecimento que permite ser utilizado em seu cotidiano, expressando "valores universais que tratam todos os seres humanos como iguais e não como membros de diferentes classes sociais, grupos étnicos ou meninos e meninas" (Young, 2011, p. 620).

${ }^{12}$ Todo currículo possui papel crítico e normativo segundo Michael Young (2014). Crítico no que diz respeito a romper com as tradições dos conhecimentos existentes no currículo, e, normativo, pois, orienta a elaboração e a prática pedagógica através da inserção de valores morais que são calcados em grupos hegemônicos, que segundo Freire e Shor (1986), mistificam a realidade reduzindo a capacidade dos envolvidos no processo de ensino-aprendizagem a contestar 0 sistema, pois, cria um padrão de conhecimento julgador, que segundo Young (2014) é especializado e define o tipo de educação que será desenvolvida na escola.
} 
professor ela é um objeto ou conceito, para o aluno, esta relaciona-se ao lugar da experiência.

Outro exemplo que expressa muito bem esta inter-relação entre conhecimento prévio e especializado pode ser identificado num fragmento do primeiro episódio, da primeira temporada, da série televisiva "Cidade dos Homens" (2002). Quando a professora chega em sala de aula e se depara com uma turma por demais arruaceira. Com objetivo de ministrar uma aula da história sobre o período colonial brasileiro, com recorte na era napoleônica, a professora utilizando data show - faz uma apresentação em imagens do tema. A dificuldade dos alunos em associar o conteúdo dado à realidade por eles vivida fica nítida quando Douglas Silva, atuando como Acerola, pergunta se as armas do Exército eram armas presentes em sua realidade como a pistola, 762, ponto 30.

Antes da aula acabar, a professora, juntamente com os alunos combina de levá-los em outra oportunidade à Cidade Imperial (Petrópolis). Ao chegar na aula seguinte, a mesma pergunta se alguém lembrava do tema trabalhado na aula anterior. Porém, os alunos só sabiam falar do passeio, o que fez a professora ameaçar cancelá-lo.

Frente a isto, Acerola se propõe a explicar o conteúdo para seus amigos, dizendo:

É o seguinte, este aqui é o morro francês, onde um maluco chamado Napoleão mandava, era o dono e ele mudou o jeito dele mandar. Esse aqui era o morro vizinho, e, ele queria que o morro vizinho fosse da mesma maneira que o dele. Antes disso a parada era dos ingleses que vendia bagulho para toda a região. Mas Napoleão venceu de pouquinho a pouquinho e impediu os morros de comprar bagulho da Inglaterra.

Os ingleses ficaram boladão e deram o coro nesses filhos da puta [...]. Primeiro eles invadiram o morro dos espanhóis e fechou a boca dos ingleses que ele tinha lá, e, depois caiu matando no morro do alemão.

Assim que ele dominava o morro, ele dava pros chegado dele tomar conta porque era muita boca pra tomar conta. Ai o Zé Bunda foi querer invadir essa parte que é gelada e os soldados dele acabaram dançando. Aí ele tava quase invadindo o morro de Portugal. E Portugal o jeito era fugir...

- Para onde? (pergunta a professora)

Praqui professora no morro da América que também era deles.

- Mas porquê? (pergunta novamente a professora)

Porque a Inglaterra é um comércio grande, o comércio é maior. Aí o jeito era os portuga pedir ajuda pros ingleses. 
Como observado nos exemplos selecionados, os conhecimentos prévios são oriundos do lugar de experiência, referem-se a conceitos cotidianos adquiridos através de experiências e propósitos específicos, que se relacionam a problemas e contextos singulares necessários para a vida em sociedade, podendo ser prático e procedimental. Prático no sentido de reparar defeitos mecânicos ou elétricos por exemplo, e, procedimental como conjunto de regras dependentes de determinada especificidade. Assim sendo, tanto o conhecimento prévio quanto especializado, possuem histórias que oferecem maneiras de generalizar para além da experiência com o cotidiano (YOUNG, 2007; 2011).

Generalização que através da mecanização do conhecimento, fragmenta-o, impedindo, por parte dos envolvidos no processo de ensino-aprendizagem, a percepção inter-relacionada entre o global e o local, compartimentando e desunindo o conhecimento. Impedindo "tratar corretamente os problemas particulares que só podem ser propostos e pensados em seu contexto". (MORIN, 2000, p. 41)

Isto posto, tanto o conhecimento prévio quanto o conhecimento especializado são importantes elementos para a construção do conhecimento escolar devido ao fato de a inter-relação entre ambos buscar:

entender o pensamento que separa e que reduz, no lugar do pensamento que distingue e une. Não se trata de abandonar o conhecimento das partes pelo conhecimento das totalidades, nem da análise pela síntese; é preciso conjugá-las. Existem desafios da complexidade com os quais os desenvolvimentos próprios de nossa era planetária nos confrontam inelutavelmente. (MORRIN, 2000, p. 46).

Fazendo com que o conhecimento seja ao mesmo tempo biológico, psíquico, social, afetivo e racional, possuidor de dimensões históricas, econômicas, sociológica, religiosa e outras, interligadas a desejos e paixões humanas pessoais (MORIN, 2000).

Este caráter complexo do conhecimento tem como característica unir a unidade à multiplicidade, para então promover uma “"'inteligência geral” apta a referir-se ao complexo, ao contexto, de modo multidimensional e dentro da concepção global". (MORIN, 2000, p. 39). A inter-relação entre estas características do conhecimento quando aplicadas ao conhecimento prévio e especializado, vem a proporcionar aos envolvidos no processo de ensino- 
aprendizagem de geografia situarem-se no espaço que estão inseridos de maneira a transformá-lo.

Ao reconhecer a validade da relação entre ambos os conhecimentos, reconhece-se também a importância do conhecimento pertinente para este processo. Conhecimento esse que deve ser evidente para o estudante, possibilitando, através da inter-relação entre o conhecimento prévio e especializado, tratar dos problemas através de uma operação, organização e mobilização do conhecimento; buscando referências tanto locais quanto globais que venham a potencializar e mobilizar os estudantes a fim de superar a supremacia imposta pelo significado ontológico do ano de 1492 (MORIN, 2000).

Assim, a inter-relação do conhecimento prévio para com o conhecimento específico se encontram em campos opostos: teoria da aprendizagem significativa e conhecimento poderoso. Posto isso, é importante destacar as possíveis aproximações entre as duas ideias e suas respectivas contribuições para odesenvolvimento de um pensamento decolonial de geografia escolar. A teoria da aprendizagem significativa, entende que o conhecimento escolar para ser construído de maneira a transformar a realidade do aluno necessita de uma troca de significados e sentimentos afetivos, proporcionando o estudante a manifestar "uma disposição para relacionar o novo material de modo substantivo e não arbitrário a sua estrutura de conhecimento (MOREIRA, 2011, p. 36).

Este processo, como destacado por Moreira (2011), constrói um conhecimento que se relaciona a formas não arbitrárias, relacionadas a conteúdos

de maneira específica que servem de matriz ideológica e organizacional para a compreensão e fixação de novos conhecimentos, que se encontram relacionados à ideias simbolicamente expressas, concebidas e propostas de maneira significativa que interagem com o conhecimento escolar, e, fazem como destacado por Adriana Pelizzari et al (2002), com que seja potencializado através da valorização do conhecimento prévio do estudante, incentivando-o a (re)descoberta de conhecimento.

À vista disso, o conhecimento escolar incorpora, em sua construção, as estruturas do conhecimento pertencente ao estudante. Neste sentido, devem-se considerar, segundo a autora, duas condições necessárias ao processo de construção do conhecimento através da aprendizagem significativa: a necessidade de os envolvidos no processo de ensino-aprendizagem estarem dispostos a 
aprender; o conteúdo escolar deve não só se apoiar em um conhecimento especializado, mas também incorporar em sua estrutura a valorização do conhecimento prévio carregado pelo estudante. Assim, permite-se que o conhecimento escolar se organize através da descoberta de novos conhecimentos, não se limitando apenas ao conhecimento especializado dado pelo currículo e disciplinas escolares.

Ao se organizar pela experiência carregada pelo estudante, a aprendizagem significativa, segundo a Pelizzri (2002), faz com que o conhecimento escolar não se limite a uma cópia de livros didáticos ou do discurso proferido pelos professores nas aulas, mas a uma reelaboração pessoal que considera as potencialidades do conhecimento prévio e do conhecimento especializado no processo de construção do conhecimento escolar. Por conseguinte, é importante destacar que:

o estudante possui papel fundamental na atribuição de significado aos conteúdos, pois também dependerá dele a escolha de aprender o que está sendo trabalhado pelo professor, ou buscar relacionar as matérias trabalhadas em sala de aula com as experiências e conhecimentos prévios. (BORGES; FARIAS, 2012, p. 63).

Esta relação significativa para com o conhecimento escolar permite que os conteúdos escolares sejam trabalhados de maneira "contextualizada com a realidade local". (BORGES; FARIAS, 2012, p. 66). Como também faz com que os estudantes adquiram "capacidade de interpretar e compreender a realidade e atuar ativamente na sociedade”. (BORGES; FARIAS, 2012, p. 67).

Ao considerar também o conhecimento poderoso como um elemento necessário para a construção de um conhecimento escolar de geografia decolonial, permite-se aos envolvidos no processo de ensino-aprendizagem avancem em sua aprendizagem "independente do contexto, diferentemente do conhecimento baseado na experiência que os alunos trazem para a escola" (YOUNG, 2016, p. 33-34). Este avanço para ser realmente efetivo, dependerá da forma com que os conceitos serão recontextualizados.

Recontextualização que é aqui entendida como um "movimento de tirar o conhecimento especializado do contexto acadêmico para colocá-lo em um novo contexto, o da disciplina escolar". (BERNSTEIN, 1996 apud YOUNG, 2016, p. 34). Este movimento, faz com que o conhecimento especializado possua uma potencialidade que não se limita "bases para a generalização, mas podem [...] representar algo sobre a humanidade em geral". (YOUNG, 2007, p. 35). 
fornecendo explicações confiáveis, novas formas de se pensar e ver o mundo que se refere "ao que conhecimento pode fazer". (YOUNG, 2007, p. 1294).

Logo, a inter-relação entre o conhecimento prévio e conhecimento especializado, junto a ideia de conhecimento pertinente; revela novas formas de conhecimento que capacitam os envolvidos no processo de ensino-aprendizagem de geografia não apenas a refletir acerca da realidade em que se encontram inseridos, como também a agir sobre a mesma.

Envolvimento que faz com que a ação docente seja fundada através da “formação de indivíduos participantes da construção da sociedade e de seus bens e valores". (FREIRE, 2016, p. 20-21). No qual o ato de ensinar é assumido como um ato de pensar de maneira ordenada frente a um objeto, no qual o "sujeito pensante, apropriando-se da significação mais profunda do objeto sendo pensado, termina por apreender a sua razão de ser" (FREIRE, 2016, p. 25). Entretanto, não podemos esquecer de destacar, que assim como a prática docente, o conhecimento pertinente deve se desenvolver através de uma pedagogia que construa "os caminhos da liberação são os do oprimido que se liberta: [Porque] ele não é coisa que se resgata, é sujeito que se deve autoconfigurar responsavelmente". (FREIRE, 2017, p. 11).

Neste contexto, cabe a escola colaborar para a construção do conhecimento através de uma formação social crítica, aberta a construção coletiva de saberes, transformando-se em um instrumento de luta transformador do sujeito e da mesma, ou seja, "Nessa perspectiva, a escola é também centro irradiador de cultura popular em permanente recriação e também espaço de organização política das classes populares”. (FREIRE, 2014, p. 203).

Dessa forma, ao reconhecer a importância do conhecimento do estudante frente à construção do conhecimento escolar, reconhecemos a importância da decolonialidade neste processo, pois, possibilitará a construção de um conhecimento escolar de geografia incorporado a exterioridades situadas para além do significado ontológico do ano de 1492.

Exterioridades, que como visto no capítulo anterior, carrega consigo novos pontos de vista acerca das relações inter-humanas, que são negados pelo significado ontológico do ano de 1492. Permitindo, segundo Aníbal Quijano (2010), uma realização histórica efetiva, com um modo de existência social possuidor de um horizonte próprio específico e alternativo que permite a criação 
de um conhecimento escolar de geografia com um "novo tipo de imaginário universal anticapitalista radical que descolonize as perspectivas marxistas/socialistas dos seus limites eurocêntricos". (GROSFOGUEL, 2008, p. 144).

Possibilitando a construção de um conhecimento que não nega o pensamento dominante, mas sujeita-o constantemente à um questionamento oriundo de "outras histórias e modos de pensar [...] permitindo uma nova relação entre conhecimento útil e necessário na luta pela descolonização epistêmica". (WALSH, 2005 apud OLIVEIRA; CANDAU, 2010, p. 2010, p. 25). Questionamento que se desenvolve de maneira especializada em espaços acadêmicos como por exemplo a Universidade Intercultural Indígena do Equador, Associação Brasileira de Pesquisadores Negros fundada em 2000, projeto "A Cor da Cultura" que foi ao ar no Canal Futura no ano de 2005, e outros espaços, mostrando que ao pensarmos o ensino de geografia decolonial; o pensamos a partir de uma:

ideia de uma prática política contraposta à geopolítica hegemônica monocultural e monorracional do conhecimento, pois se trata de visibilizar, enfrentar e transformar as estruturas e instituições que têm como horizonte de suas práticas e relações sociais a lógica epistêmica ocidental, a racialização do mundo e a manutenção da colonialidade do poder. (WALSH, 2007 apud OLIVEIRA; CANDAU, 2010, p. 28).

A ocupação desses espaços é muito importante porque oferece diferentes posições e possibilidade, propondo "outros conhecimentos e cosmovisões num diálogo com os conhecimentos e modos de pensar tipicamente associados ao mundo Ocidental" (OLIVEIRA; CANDAU, 2010, p. 26). Frente a isso, o conhecimento escolar de geografia decolonial possui um "valor pedagógico na medida em que questiona os referenciais eurocêntricos" (PENNA, 2014, p. 183). Fazendo o estudante questionar os padrões de vida impostos ao mesmo, como também a rejeitar a alienação.

Entretanto é importante destacar que ao mesmo tempo em que propomos uma educação decolonial, que venha a valorizar outras formas epistêmicas exteriores ao significado ontológico do ano de 1492, há de se reconhecer a importância do hoje na construção do conhecimento; que envolve questionamentos associados à realidade dos estudantes, capacitando-o a construir: 
uma percepção crítica da realidade opressora pelos educandos e a problematização de temas antes não questionados e de situações e condições antes assimiladas como naturais [...] superar a visão fatalista da realidade como eterna e imutável, passando-se à percepção de que ela é construída pelos homens e passível de ser transformada. (PENNA, 2014, p. 190).

Esta capacitação, para Penna (2014), permitirá a problematização e a transformação da realidade por parte do estudante; potencializando-o a: "superar a contradição opressor-oprimido por meio da objetivação do opressor como causa da situação atual e por meio da problematização e questionamento da mitologia da opressão.” (PENNA, 2014, p. 192).

Neste processo, a palavra ganha um papel fundamental, pois, é oriunda da ação/reflexão humana e tem como objetivo "pronunciar o mundo, de problematiza-lo, de modifica-lo". (FREIRE, 2005 apud PENNA, 2014, p. 192), e, construir "um olhar crítico sobre as categorias de pensamento a partir das quais construímos nosso raciocínio acadêmico". (PENNA, 2014, p. 197).: 


\section{História em quadrinhos e ensino de geografia decolonial}

No primeiro capítulo vimos como podemos usar as histórias em quadrinhos como uma contranarrativa potente para se superar o conhecimento geográfico imposto pela colonialidade do poder, saber \& ser. Mostrando como o discurso geopolítico pode ser construído através de contranarrativas que perturbam narrativas hegemônicas que "justificam visões hegemônicas e suas políticas resultantes. [...]desafia leitores e telespectadores a reconsiderar o script dominante de eventos geopolíticos" (HOLLAND, 2012, p. 108).

Posto isto, neste capítulo, iremos mostrar a relação das histórias em quadrinhos, como ferramenta pedagógica para o ensino de geografia decolonial, a fim de construir uma alternativa de ensino que vá para além do ensino tradicional. Buscando destacar as possíveis potencialidades que envolvem o fenômeno da mídia história em quadrinhos, como também sua relação para com o ensino de geografia decolonial debatido até então.

Ao adentrarmos no debate a cerca das potencialidades que envolvem o fenômeno da mídia, é importante destacar que as mesmas se encontram inseridas em um espaço mediado por relações de poder criadoras de estratégias de controle como também de "lutas de grupos e indivíduos para terem acesso e participação quanto à informação e ao direito de voz e de expressão". (SILVERSTONE, 2002 apud FISCHER, 2007, p. 293). Estas relações de poder, são cada vez mais necessárias frente ao cotidiano imposto e frente a experiências, pois, "assumem características de produção, veiculação, consumo e usos específicos em cada lugar do mundo". (FISCHER, 2007, p. 293).

Esta especificidade que a mídia carrega consigo, faz com que se construam diferentes tipos de públicos que através de seus respectivos imaginários, buscam redescobrir espaços como também construir novas e inesperadas simbolizações (FISCHER, 2005 apud FISCHER, 2007). Esse movimento faz com que cada nova tecnologia ponha o indivíduo frente a "antigas questões sobre o problema da representação e da figuração.” (DUBOIS, 2004 apud FISCHER, 2007, p. 296) posição que para a autora, aponta para caminhos a serem seguidos e enquadrados pela perspectiva de cada um. 
Desta forma, as mídias exercem na sociedade um papel de apropriação crítica e criativa, pois, são meios de comunicação que exercem determinado tipo de influência no cotidiano. Influência que se desenvolve das mais variadas formas, não se limitando a funções efetivas de controle social, mas também desenvolvem "novos modos de perceber a realidade, de aprender, de produzir e difundir conhecimentos e informações”. (BÉVORT; BELLONI, 2009, p. 10831084), que como pode ser visto pelas histórias em quadrinhos analisadas nos capítulos anteriores vem a fortalecer ou romper com a realidade imposta pelo Mito da Modernidade.

Destarte, a mídia interfere de forma direta na construção do conhecimento, pois interage com os demais processos e códigos que atuam na própria mídia a partir de processos inter-relacionados (SANTAELLA, 1992 apud CARVALHO; ARAÚJO, 2017, p.3). Este processo, para os autores, faz com que se criem novas ressignificações acerca do cotidiano, da cultura e das relações de poder existentes no espaço, para assim se criar novos tipos de relações sociais espaciais.

Essa possibilidade de criação de novas realidades faz com que o indivíduo desenvolva de forma individual sua: autonomia, auto-expressão, identidade e conhecimento (OSBORNE, 2007 apud DIÓRIO; RÔÇAS, 2013). Entretanto é importante destacar que este desenvolvimento se encontra imerso em relações de poder exercidas pela inter-relação das colonialidades expostas no primeiro capítulo.

Como exemplo temos as histórias em quadrinhos analisadas no segundo capítulo "Febre do Ouro", cuja existência ocorre a partir da veiculação de mitos, ídolos e crenças que "representam verdades inquestionáveis para fãs e adoradores, consumidores em potencial, não apenas de seus produtos como também da mitologia propagada pela empresa". (GOMES, 2001, p. 193). ssim sendo a representação contida nas histórias em quadrinhos é concretizada por redes simbólicas que carregam consigo discursos variados condicionadores da constituição da subjetividade; servindo assim de "referencial para a produção das identidades." (GOMES, 2001, p. 194).

Ao se tornar um referencial subjetivo, a mídia captura o olhar do outro através de uma realidade simulada no qual sua força perde intensidade devido à produção ilimitada de conhecimento e à visão de mundo proporcionados pela mesma (BAUDRILLARD, 1997 apud GOMES, 2001). Exercendo assim, um 
domínio de representação de discursos, imaginários, emoções, sentimentos, decisões, para assim difundir "valores, formas de viver, hábitos que afetam as identidades das pessoas, o sentido da vida, as relações humanas". (LIBÂNEO, 2006, p. 31).

Entretanto, é importante destacar que cada singularidade possui "peculiaridades e seus modos de expressão conforme classe social, inserção cultural, nível de escolarização, condições de acesso aos bens culturais". (LIBÂNEO, 2006, p. 33). Peculiaridade que condicionará a forma como o conhecimento, "representações, hábitos, comportamentos, expectativas, significados, compartilhados [...] caracterizam e orientam suas relações com outros grupos sociais”. (LIBÂNEO, 2006, p. 33).

Logo cabe destacar que a forma com que o conhecimento é construído através da mídia também se encontra presente no ensino. Esta presença acontece como visto também através da ideia de geopolítica popular no primeiro capítulo porque com "a difusão das redes de internet, a comunicação que costumava ser predominantemente unidirecional, passou a ser caracterizada pela capacidade de envio de mensagens a partir de muitos para muitos de maneira assíncrona". (DI FELICE, 2007 apud CARVALHO; ARAÚJO, 2017, p. 10).

Posto isso ao considerar a história em quadrinhos uma mídia significativa e poderosa, assume-se que sua construção é dada de forma dinâmica. Para isso é necessário certo conhecimento prático sobre a mídia passa assim combinar "com a perspectiva analítica e o conhecimento sobre as linguagens específicas dos meios". (TUFTE; CHRISTENSEN, 2009, p. 101). Ao fazer esta combinação, a mídia-educação, faz com que o conhecimento escolar e o conhecimento produzido pelos meios de comunicação se inter-relacionem de maneira a um complementar o outro (TUFTE apud TUFTE; CHRISTENSEN, 2009, p.103). Contudo, para que este processo se efetive, "É preciso que sejam desenvolvidos instrumentos conceituais mídia-educativos em relação a todas as mídias". (TUFTE; CHRISTENSEN, 2009). Como exemplo de instrumentos conceituais midiáticoeducativos podemos citar: i) Educational Vídeo Center (EVC) em Nova York e ii) Reach La em Los Angeles.

Ambos os projetos "oferecem exemplos de como a produção de mídia pode ser ensinada como um componente essencial da alfabetização crítica da mídia”. (KELLNER; SHARE, 2008, p. 707). Os projetos envolvem a produção do 
conhecimento a partir do uso crítico da mídia que insere "jovens moradores de áreas socialmente desfavorecidas do centro da cidade em atividades de produção de vídeo, nas quais exploram suas preocupações e criam sua mídia alternativa para desafiar as representações dominantes”. (KELLNER; SHARE, 2008, p. 707).

O uso crítico da mídia, como nos exemplos citados, buscam não apenas a incorporação da mídia como recurso didático, mas como uma forma de problematizar as narrativas hegemônicas estruturadas pelo Mito da Modernidade e praticadas através da colonialidade, que juntas impõem sentidos à modos de viver e condições sociais (TERUYA, 2009).

Logo, a mídia quando usada de forma crítica no ensino de geografia vem a: instigar o sujeito a relacionar o conhecimento novo ao velho. É precisamente aqui que vemos sua maior contribuição: a possibilidade de construção do conhecimento em uma área, respeitando a mesma sequência do processo de construção das estruturas do conhecimento. (PIAGET, 1990; PIAGET; GARCIA, 1983; 1987 apud STOLTZ, 2005, p. 152).

Ao instigar o sujeito a inter-relacionar o novo conhecimento ao velho, a mídia história em quadrinhos aparece para o mesmo como um meio de potencializar a relação entre ensino/aprendizagem que torna "a ação educativa mais significativa e atrativa aos sujeitos envolvidos no processo educacional." (PEREIRA; AKAICHI, 2015, p. 312). Ao tornar a ação educativa mais significativa, amplia as "oportunidades de aprendizagem de maneira crítica e contextualizada, pois possibilita a elaboração e apreensão do conhecimento de forma sistematizada e ordenada". (PEREIRA; AKAICHI, 2015, p. 312). Permitindo aos envolvidos no processo de ensino e aprendizagem uma participação mais efetiva e crítica sobre suas respectivas realidades: decodificando, entendendo, comunicando e criando novos produtos de mídia (PECHULA; GONÇALVES; CALDAS, 2013). Sendo importante destacar também que seu uso crítico no ensino não se limita apenas a modelos pedagógicos rígidos, mas também se refere a "pontos de referência interpretativos, a partir dos quais os educadores podem estruturar seus objetivos, interesses e estratégias". (KELLNER; SHARE, 2008, p. 702-703).

Outro aspecto importante a ser destacado no âmbito desta pesquisa é que ao assumir a mídia história em quadrinho como um dispositivo pedagógico crítico se assume também que as relações que permeiam sua criação e posterior divulgação encontra-se imersa em relações e lutas de poder que são mediadas por estratégias 
de controle globalizadas (SILVERSTONE, 2002 apoud FISCHER, 2007) que permitem a revelação de contranarrativas que permitam a "aquisição do pensamento crítico [...] inserção e percepção direta do aluno como agente mobilizador na sua realidade" (CALDAS, 2006, p. 129).

Entretanto, o uso da mídia no ensino varia de acordo com a disciplina e também, com a forma como é utilisada pelo professor. Posto isso, nesta parte do capítulo exporemos as contribuições que o uso da mídia para com o ensino de geografia pode trazer para a construção de um conhecimento escolar de geografia decolonial. Porque como destacado por Gilberto Budai et al. (2018), nos Parâmetros Curriculares Nacionais, a geografia escolar não é mais encarada como uma disciplina enciclopédica que expõe fatos lineares, mas como uma disciplina que tem como objetivo formar "cidadãos críticos que tenham a clareza das relações sociais no espaço-tempo geográfico". (BUDAI et al., 2018, p. 17), que segundo os autores citados, permite que o aluno localize, compreenda e atue em sua realidade, problematizando-a através de formulações de proposições e reconhecimento das inter-relações existentes no espaço geográfico.

À vista disso, assume-se que o ensino de geografia deve formar cidadãos críticos que agem na realidade a ponto de transforma-la. Este modo de agir encontra-se associado a dinâmicas espaciais, que devido ao processo de globalização são intensificadas a ponto de contribuir para uma mudança significativa na forma de viver e de perceber a realidade imposta. Podemos entender que um dos desafios à aplicação de um ensino de geografia decolonial significativo e poderoso é "compreender as transformações da realidade do ponto de vista espacial." (GUIMARÃES, 2007, p. 47). Para assim, "fazer uma leitura crítica da mídia e se apropriar desses conhecimentos para o exercício da cidadania." (DIÓRIO; RÔÇAS, 2013, p. 57).

Ao se apropriar do conhecimento significativo e poderoso; os estudantes são motivados a "cultivar e exercer as práticas sociais envolvidas com a ciência, ou seja, fazer parte da cultura científica." (DIÓRIO; RÔÇAS, 2013, p. 57). Seu uso por parte dos professores também, (re)define práticas pedagógicas, que se desenvolvem com o objetivo de responder pertinentemente aos "múltiplos desafios das sociedades da informação na perspectiva de um enriquecimento contínuo dos sabres e do exercício de uma cidadania adaptada às exigências do nosso tempo" (UNESCO, 1996 apud DIÓRIO; RÔÇAS, 2013, p. 57). 
Posto isso, podemos afirmar que a mídia história em quadrinhos, quando usada como ferramenta pedagógica no ensino de geografia; instiga a uma leitura do mundo e dos próprios meios de comunicação mais crítica, os ressignificando de maneira poderosa e permitindo por parte dos envolvidos no processo ensinoaprendizagem da geografia uma "tomada de decisão acerca de situações problemas que são propostas a todo o momento na sociedade da informação." (DIÓRIO; RÔÇAS, 2013, p. 65).

Entretanto, quando usada para o ensino de geografia, a mídia história em quadrinhos proporciona ao professor diferentes tipos de comunicação e linguagem que motiva/instiga os alunos a "produzir e expressar ideias, opiniões, sentimentos e conhecimentos sobre o mundo". (GUIMARÃRES, 2007, p. 50). Produção e expressão que desenvolvem um conhecimento geográfico escolar que entende que as novas e velhas dinâmicas são dadas no espaço, pois, são "fruto da sociedade ao longo do processo histórico". (GUIMARÃES, 2007, p. 51). Este entendimento faz com que a mídia sirva para os alunos como uma ferramenta de (re)interpretação da realidade, mostrando que "existem outras realidades, outros acontecimentos e fatos por detrás daquilo que nossos olhos conseguem captar." (GUIMARÃES, 2007, p. 54-55).

Ao explorar outras Cosmovisões frente ao conhecimento escolar de geografia, o estudante a faz a partir de suas experiências pessoais no mundo que tem como objetivo "colocar os indivíduos em contato com os "outros", em outros tempos e espaços.” (GUIMARÃES, 2007, p. 55). Neste processo, o uso das mídias no ensino de geografia decolonial ganha relevância porque possui "um papel dos mais importantes na vida cotidiana dos cidadãos, especialmente, em relação à percepção e à construção de novos sentidos de espaço e tempo." (GUIMARÃES, 2007, p. 58).

Este papel se fortalece porque a mídia cria uma percepção geográfica no qual o espaço-mundo como fenômeno instantâneo, constrói espaços que são divulgados através de fatos e notícias que estabelecem inter-relações entre o que aconteceu e o que está acontecendo (SARLO, 2000 apud GUIMARÃES, 2007).

Ao facilitar o entendimento do conhecimento, a mídia ${ }^{13}$, age como motivadora do gosto pelo conhecimento geográfico. Construindo-o de maneira a

13 É importante destacar como o caráter perverso da mídia ajuda na (re)produção de um conhecimento dado pela inter-relação entre as ideias já debatidas de colonialidade. Esta crítica é 
auxiliar "mecanismos que fazem funcionar determinados processos de significação no contexto atual, caracterizado pela intensa circulação de sentidos". (GUIMARÃES, 2007, p. 62). Para assim, proporcionar "o desenvolvimento de novos conhecimentos, assim como uma contextualização e significação dos conceitos apreendidos”. (PEREIRA; ALVES; CABRAL, 2013, p. 17).

Esta criação faz com que o processo de ensino-aprendizagem de geografia configure e/ou modifique a ação, tanto de comunicação quanto de informação, para assim, dirigir seu conhecimento em direção à experiência do estudante "para que ele atinja, com a inter-relação das novas tecnologias, o objetivo principal, a aprendizagem. A natureza e a extensão dessa aprendizagem são particularizadas pelas categorias curriculares". (SOUZA; QUEIROZ, 2012, p. 69-70).

Extensão, que faz com que os conteúdos geografia escolar sejam desenvolvidos de maneira mais dinâmica e lúdica, o que, por sua vez, faz com que o estudante se sinta incentivado em "estudar o espaço geográfico da sua própria rua [...] analisar como vivem as sociedades, como ocupam o espaço geográfico e como é a relação social desse contexto" (SOUZA; QUEIROZ, 2012, p. 72).

Logo, quando usada de maneira significativa e poderosa, a história em quadrinhos pode vir a contribuir para o desenvolvimento de um conhecimento escolar de geografia decolonial, pois, como visto ao longo deste capítulo; permite que se faça uma leitura crítica não apenas da realidade como também da mídia. Leitura que é pertinente porque através do que é significativo para o estudante,

necessária, pois, tem como objetivo "mostrar como na sociedade moderna a cultura transformouse em uma grande força capaz de transmutar a arte em qualquer mercadoria". (SANTOS, 2014, p. 26) - como exemplo temos os produtos Disney e Maurício de Souza - que perdem seu valor crítico através da imposição de uma realidade sujeita "aos interesses do capital". (SANTOS, 2014, p. 27), proporcionando assim aos indivíduos possibilidades de divertimento que buscam de forma direta e indireta introduzir "modos próprios de trabalho" (SANTOS, 2014, p. 30). Essas possibilidades, fazem com que a mídia esteja presente na vida "da grande maioria da população brasileira [...] no qual a intimidade das pessoas é o objeto central do espetáculo". (CHAUÍ, 2006, p. 5).

Destarte não podemos nos envolver por ilusões de quimeras e achar que o conhecimento produzido pela mídia possibilita, apenas, um conhecimento crítico capaz de romper com as narrativas hegemônicas construídas através da colonialidade. Esta possibilidade se torna inviável, pois, a mídia como entretenimento - impossibilita a diferenciação entre "a aparência e o sentido, o virtual e o real, pois tudo nos é imediatamente dado sob a forma da transparência temporal e espacial das aparências, apresentadas como evidências". (CHAUÍ, 2006, p.32-33). Este vácuo, para a autora, é preenchido por promessas e ofertas de gratificação instantânea criador de desejos que buscam a todo instante a satisfação individual do indivíduo, ou seja, a mídia fortalece o conhecimento produzido pela inter-relação entre as ideias de colonialidade do poder, saber e ser, "oferecendo-se como um gigantesco espelho no qual devemos ver nossa própria imagem, que parece estar ali simplesmente refletida quando, na verdade, foi deliberadamente produzida para obter o efeito da identificação narcisista". (CHAUí, 2006, p. 54-55). 
cria possibilidades poderosas para o mesmo agir e transformar a realidade na qual está inserido. 


\section{5 \\ Nem tudo é teoria: a arte de quadrinizar o conhecimento escolar de geografia decolonial}

Quando associado as histórias em quadrinhos pela perspectiva da decolonialidade e geopolítica popular debatida em capítulos anteriores ao ensino de geografia de forma prática, proporciona-se aos envolvidos se inserirem em um processo criativo que "é ao mesmo tempo individual, no quesito onde a introspecção acontece no momento de incubação, e coletiva, onde comunicamos e apresentamos ao contexto social" (RATO, 2009 apud (GRINGON, 2014, p. 15).

Permitindo aos estudantes "reconhecer os conhecimentos invisibilizados pelo colonialismo [...] e a implementação da matriz moderno/colonial" (FERREIRA-BALANQUET, 2017, p. 456). Fazendo-os perceberem-se através da "relação existente entre o homem e o lugar em que vive". (NETO; PACHECO, 2018, p. 160). Para assim, construir uma Cosmovisão que permite "ampliar a compreensão de abordagens em vários aspectos do cotidiano humano". (NETO; PACHECO, 2018, p. 161).

Ampliação quando associada ao conhecimento escolar de geografia, permite "identificar fenômenos a serem filtrados pelo leitor e aproximar a percepção de categorias geográficas" (NETO; PACHECO, 2018, p. 161). Isto é possível porque quando produzidas por meio da perspectiva da geopolítica popular e do giro decolonial debatido em capítulos anteriores, as histórias em quadrinhos:

mesmo não pretendendo ser e não sendo um mero registro histórico, acabam sendo também uma historiografia inoficial. Na medida mesma em que não querem ser documento, seu caráter autônomo lhes permite uma liberdade de registro e transmissão que escapa à historiografia oficia, comprometida com as omissões, cortes e deformações que as relações de produção lhe impõem. (KOTHE, 1976 apud NETO; PACHECO, 2018, p. 161).

Comprometimento que associado ao imaginário e visão de mundo dos envolvidos no processo de produção de histórias em quadrinhos, através do ensino de geografia decolonial; desenvolve "a compreensão das imagens codificadas [...] que se transformam em paisagem recheadas de sentimentos e subjetividades". (NETO; PACHECO, 2018, p. 164).

Compreensão que se exterioriza neste trabalho através dos gritos dos envolvidos neste processo. Gritos que são uma forma de "expressar os 
sentimentos de frustração, indignação, raiva, dor e horror [...] produto e reflexo da acumulação de um sentir" (WALSH, 2017, p. 66). Uma forma "integral de como e onde me posiciono politicamente, epistemologicamente, eticamente e estrategicamente" (WALSH, 2017, p. 82).

Destarte, fica claro neste processo a importância, por parte dos indivíduos envolvidos no processo de ensino e aprendizagem de geografia, da tomada da consciência que os permitem se entender como possuidores da própria história. Tornando o conhecimento escolar de geografia um instrumento que "exerce a função de favorecer o direito e o dever de refletir, criticar e procurar os meios necessários à condução dos processos que conduzem à materialização de escolhas sociais”. (CABRAL, 1978 apud VILLEN, 2013, p. 202). Posto isso, é importante destacar que os indivíduos no processo de ensino e aprendizagem de geografia, não são encarados como simples criaturas, mas como sujeitos capazes de "reagir [contra] forças que modelam as estruturas de classe e as mentalidades". (MEINTEL, 2006 apud VILLEN, 2013, p. 201).

Assim, a Arte de Quadrinizar é uma expressão usada por Ivan Brunetti (2013) em seu livro: “A arte de quadrinizar: filosofia e prática”. Arte que confere uma "linguagem humana uma forma visual perpétua, dotando-a de existência independente". (BRUNETTI, 2013, p. 1). Existência que quando associada à expressão quadrinizar, faz com que seja "um meio prático pelo qual o quadrinista amador pode vir a descobrir-se criativamente". (BRUNETTI, 2013, p. 1).

Visão esta, que faz com que as histórias em quadrinhos quando usadas no ensino de geografia decolonial, permita o desenvolvimento e construção de um conhecimento que permite estruturar e captar o mundo através do ponto de vista de quem o produz, que faz das histórias em quadrinhos um meio de expressão decolonial com espaços inexplorados que são criados por quem as produz (BRUNETTI, 2013). Destarte, quando produzidas, as histórias em quadrinhos carregam consigo uma visão de mundo e discurso singular, que faz com que se construa um sistema "coerente e identificável de sinais comunicativos que expressam a experiência única que cada um de nós tem da vida" (BRUNETTI, 2013, p. 18).

Experiência possuidora de "forma" e "conteúdo", que faz com que o ato de desenhar uma história em quadrinhos, por meio da perspectiva geográfica decolonial debatida no primeiro capítulo, construa a realidade por meio da 
experiência e representação de "fenômenos externos como estados emocionais". (BRUNETTI, 2013, p. 65). Não se limitando aos padrões impostos pelo significado ontológico do ano de 1492 debatido no primeiro capítulo, permitindo o desenvolvimento de um conhecimento escolar geografia decolonial, que sirva de "um instrumento de luta [...] e não simplesmente algo a ser apresentado por ocasião dos testes e provas" (FREITAS, 2018, p. 128).

$\mathrm{O}$ que permite o exercício de uma responsabilidade "horizontalizada e participativa [...] baseada em outra concepção de sociedade e educação, com a intencionalidade de propiciar uma igualdade de condições para todos". (TRAVITZKI, 2013; DI CARLO, 2010 apud FREITAS, 2018, p. 130). Exercício que é possível através do reconhecimento de "fatores externos importantíssimos que afetam as possibilidades formativas dos estudantes, por exemplo, sua realidade de vida". (TRAVITZKI, 2013; DI CARLO, 2010, p. 130).

Fatores externos que carregam significados relacionados à visão de mundo e experiência de quem o produziu, carregando - como visto pela ótica da geopolítica popular - um discurso geopolítico que posiciona a história em quadrinho em um contexto, que possibilita a reconstrução e reinterpretação das relações de poder impostas pela racionalidade do conhecimento moderno. Reconfigurando as estruturas do conhecimento impostas pelo significado ontológico do ano de 1492, para então, permitir encarar a produção das histórias em quadrinhos como uma forma de se construir contranarrativas reveladoras de novas formas de se pensar o conhecimento escolar de geografia. Mostrando que determinados elementos existentes no espaço não podem ser reduzidos à objetivação imposta pela colonialidade do poder, saber e ser, pois, os espaços construídos através das histórias em quadrinhos expõem signos e revelam condições que dão "à realidade geográfica um tipo de animação e de fisionomia em que ele revê sua experiência interior ou social". (DARDEL, 2015, p. 6).

Esta experiência por meio da Arte de Quadrinizar a geografia, oferece assim representações exteriores que auxiliam na construção de significados que rompem com o cotidiano "trazendo novas formas de relações para com um espaço, criando um novo sentido para o mesmo, como também uma lógica para o uso de seus objetos.” (MENDONÇA; REIS, 2016, p. 58 Fazendo com que o conhecimento escolar de geografia não carregue apenas "mapas mentais do espaço geográfico em suas cabeças, mas também podem transcrevê-los em 
palavras, diagramas e mapas quando necessário" (TUAN, 1990, p. 441). Transcrição que "promove a sensação de um mundo compartilhado". (TUAN, 1990, p. 441). Permitindo aos envolvidos no processo de ensino aprendizagem de geografia se "libertar da cultura estabelecida". (TUAN, 1990, p. 443).

Logo, ao entender as histórias em quadrinhos - por meio da Arte de Quadrinizar - como um elemento importante para se pensar o conhecimento proposto neste trabalho, se assume que ela é importante para o conhecimento escolar de geografia, porque permite o desenvolvimento de uma visão de mundo geográfica que não se restringe a realidade imposta pelo significado ontológico do ano de 1492. Esta expansão fornece assim "um conhecimento semelhante ao da ciência empírica [...] isto é, para mostrar a inserção da vida em um ambiente ou paisagem”. (TUAN, 1990, p. 444). O que faz, com que o conhecimento escolar de geografia não seja apenas um "conhecimento básico adquirido das necessidades da vida; é também um projeto intelectual-imaginativo" (TUAN, 1990, p. 444).

\section{1 \\ Uma proposta para quadrinizar o conhecimento escolar de geografia decolonial}

Nesta subseção, exporemos a metodologia da atividade realizada que teve como objetivo referenciar a mídia história em quadrinhos, como uma forma de construir discursos geopolíticos hegemônicos e contra hegemônicos, que permitem reinterpretar a realidade a ponto de construir um discurso que não situa o indivíduo apenas no processo de ensino de ensino aprendizagem de geografia, como também no espaço que está inserido.

A atividade fora realizada com dois grupos ${ }^{14}$ de alunos do oitavo ano do Cap-UERJ. O conteúdo escolhido - tendo como parâmetro o currículo mínimo do Rio de Janeiro - fora o conhecimento americano e sua diversidade, no qual a habilidade e competência a ser destacada foi: identificar as características étnicoculturais dos povos americanos, relacionando-as às matrizes europeia, africana e indígena na construção da identidade da população do continente americano.

\footnotetext{
14 A divisão dos grupos se deu pela questão da disponibilidade dos horários dos professores envolvidos. Como também o motivo para a atividade ser feita em dois momentos no primeiro grupo e apenas uma no segundo.
} 
Assim sendo é importante destacar que a atividade desenvolvida fora executada através do uso da internet, devido ao fato de o ano 2020 ter sido marcado pela pandemia de COVID-19, impedindo a prática direta com os alunos. Logo, não é porque está sendo feita de forma não presencial, que perde seu valor crítico. Porque como visto em capítulos anteriores, através do audiovisual da Turma da Mônica, essas novas comunicações criam "novas formas de ação e interação no mundo social, novos tipos de relações e novas maneiras de relacionamento do indivíduo com o outro e consigo mesmo". (NICOLAU; MAGALHÃES, 2013, p. 69).

Dessa forma, o primeiro momento da atividade se deu pela distribuição de um texto de apoio (Anexo I) para os estudantes lerem antes da atividade. Tendo como objetivo provoca-los frente a atividade que viria a seguir. $O$ segundo momento da atividade, com apresentação em power point (Anexo II), consistiu em um debate provocativo através da seguinte pergunta: “Qual sua relação com as histórias em quadrinhos?", com objetivo de expor o objetivo da atividade.

No terceiro momento, com o uso também do power point (Anexo II), tivemos como objetivo o que é A Arte de quadrinizar o conhecimento escolar de geografia. Posto isso, foram feitas quatro perguntas: i) $\mathrm{O}$ que são histórias em quadrinhos? ii) Quem produz as histórias em quadrinhos? iii) Qual visão de mundo as histórias em quadrinhos constroem? iv) Qual relação das histórias em quadrinhos com o conhecimento escolar de geografia?

Após, no quarto momento, usando novamente o Mundo Disney, mas desta vez com Zé Carioca ${ }^{15}$ recebendo Pato Donald no Rio de Janeiro ${ }^{16}$, buscou-se mostrar elementos que como a mídia se articulam com a visão de mundo imposta pelo significado ontológico do ano de 1492, a fim de reforçar uma visão de mundo moderna, que como visto no primeiro capítulo, é dada a partir das colonialidades exploradas. Para assim, no quinto momento, através das duas

15 Como visto no capítulo três, o mundo Disney carrega uma visão de mundo, que através do Mito da Modernidade, a reproduz um mundo hegemônico, que através de histórias e personagens criam "meios de produzir a vida [...] as ideias, os sentimentos, as intuições; numa palavra, o sentido do mundo”. (DOFRMAN; MATTELART, 2010, p. 154).

Quando nos referimos ao Brasil, Zé Carioca é o personagem que o representa, com uma criação que mostra "a preocupação dos artistas do Estúdio Disney de captar e usar como estofo dos personagens características reais dos brasileiros". (SANTOS, 2002, p. 3). Características que podem ser vistas, no trecho a ser passado, criando uma visão generalizada do que é ser brasileiro, como: "falastrão, afetuoso, simpático e hispitaleiro". (SANTOS, 2002, p. 3).

16 PERILLO, Daniella. Donald Duck \& Zé Carioca - Walt Disney. 2018. (4"52s). Disponível em: $<$ https://www.youtube.com/watch?v=oktf8JLmSDc>. Acesso em: 20 mar. 2021. 
tirinhas a seguir da personagem Mafalda ${ }^{17}$, expor como as mídias contribuem para a construção de contranarrativas que têm como objetivo construir novos significados frente à realidade dada.
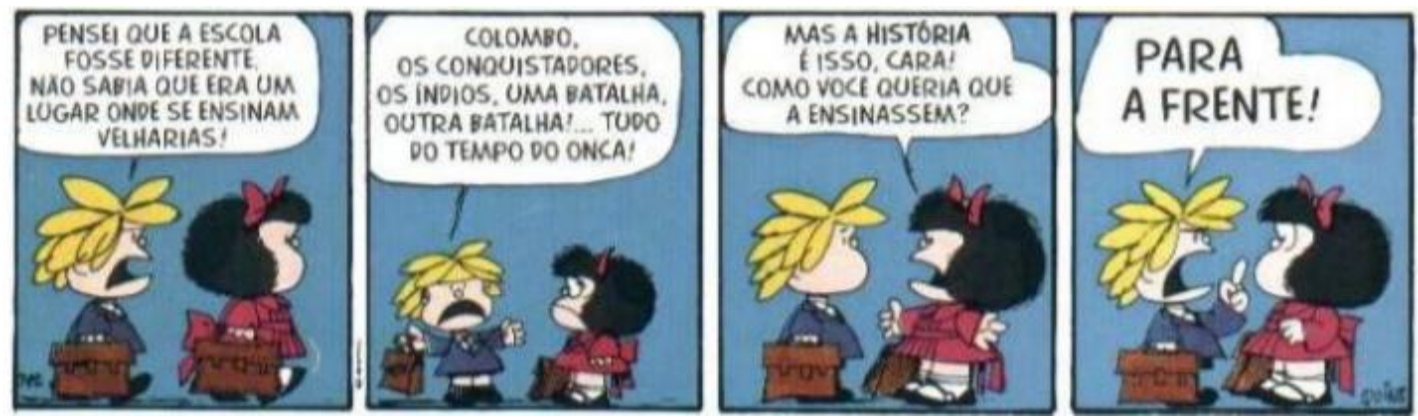

Figura 7 Conhecimento escolar I

Fonte: Quino (2003, p. 164, tira 1)

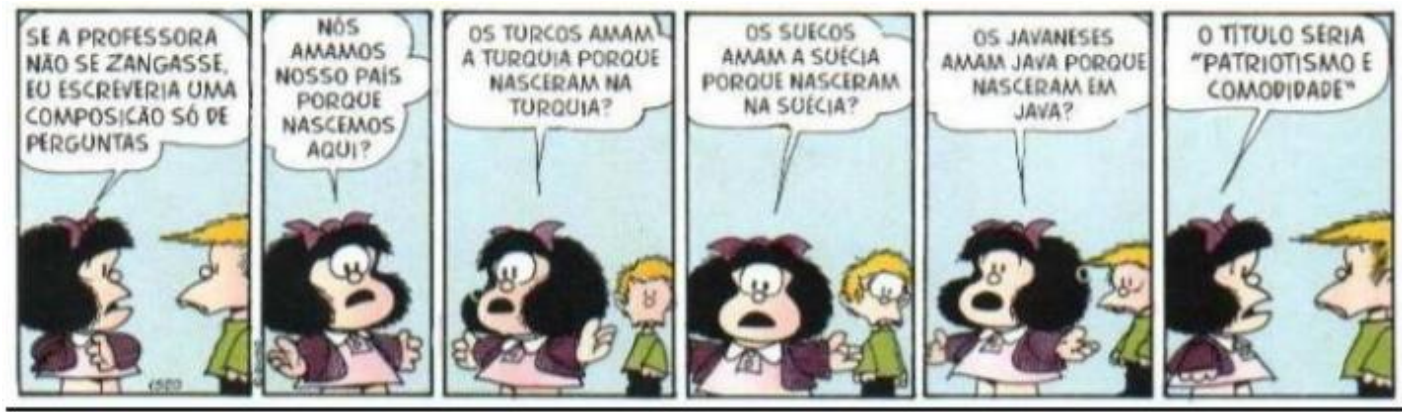

Figura 8 Conhecimento escolar II

Fonte: Quino (2003, p. 326, tira 4)

No sexto momento, buscando aproximar a teoria da prática, também através do uso do power point (Anexo II), trouxemos histórias em quadrinhos de diferentes tempos e geografias, com intuito de mostrar formas de se produzir uma história em quadrinho. Mostrando que a produção das histórias em quadrinhos não se limita a um grupo social, sendo externalizadas através de um diálogo entre a experiência e visão de mundo de quem a produz. Por fim, no sétimo momento, os estudantes, em grupos organizados pelos mesmos, enviaram suas produções para a plataforma da escola em que a atividade foi aplicada.

\footnotetext{
17 Mafalda é "uma menina que vive a questionar o mundo e que tem os sentidos muito aguçados sobre aquilo que não vê sentido. Em muitas de suas histórias, põe-se a questionar". (GIROTTO; SANTOS, 2011, p. 147). Questionamento que como visto carrega consigo um discurso contra hegemônico, que por meio das mídias, busca representar a realidade através de uma visão de mundo exterior a realidade imposta pelo Mito da Modernidade.
} 


\subsection{1 Resultados alcançados}

Nesta parte do trabalho iremos mostrar, como na prática, a produção das histórias em quadrinhos através da perspectiva da geopolítica popular, podem contribuir para pensarmos um ensino de geografia decolonial que permite aos estudantes se posicionar "politicamente, epistemologicamente, eticamente e estrategicamente" (WALSH, 2017, p. 82).

No entanto, como a atividade fora feita em dois grupos, que chamaremos nesse trabalho como grupo A \& grupo $\mathrm{B}$, iremos na seção "Oficina a Arte de Quadrinizar o conhecimento escolar de geografia decolonial”, trazer as narrativas dos estudantes dos dois grupos. Para nas seções seguintes, mostrarmos suas produções e relação com a proposta aqui debatida.

\subsubsection{1 \\ Oficina a Arte de Quadrinizar o conhecimento escolar de geografia decolonial}

$\mathrm{Na}$ provocação feita aos alunos no que diz respeito a suas relações com as histórias em quadrinhos, tivemos várias respostas que mostraram que as histórias em quadrinhos se encontram presente no cotidiano das pessoas, seja em um passado distante ou presente. Como exemplo a destacar temos as seguintes falas: i) "Lia quando era criança e tinha acesso através de assinatura mensal"., ii) "Fizeram parte da minha infância, sempre ia com minha família, minha mãe, comprar revistinha na banca de jornal"., iii) "Eu não gosto porque tem letras pequenas, mas minha mãe falou que a Marvel tem a ver com a guerra fria”.

Quando questionados sobre o que eram então as histórias em quadrinhos, dentre as várias respostas, destacaremos as seguintes: i)“É uma maneira de contar histórias, usando traços e textos para explicar. Claro, carregando contextos sociais e ideologias políticas, porque sempre existe uma relação de poder entre quem lê e quem escreve" e ii) "Diferentes formas de ver o mundo"

Posto isso, os trechos destacados nos mostram, por parte dos estudantes, uma Cosmovisão, que como destacado por Walsh (2017), traz consigo um conhecimento que o permite se posicionar frente a inter-relação das colonialidades 
debatidas em capítulos anteriores. Posicionamento, que fica claro na última oração do penúltimo trecho destacado, quando o estudante traz para o debate a influência que as histórias em quadrinhos exercem sobre a sociedade que a consome indo de encontro com a ideia da geopolítica popular aqui já debatida.

Ao responder quem produz as histórias em quadrinhos os envolvidos na atividade trouxeram inúmeras contribuições como: i) “As histórias em quadrinhos, quando produzida por grandes empresas, são produzidas através da divisão de tarefas"., ii) "Como qualquer mídia artística, existem empresas que produzem isso, mas também existem histórias em quadrinhos independentes"., iii) "Escritor, desenhista, cartunista"., iv) "Roteirista, design".

Assim, os trechos destacados, nos mostram um certo distanciamento do indivíduo neste processo, dando a entender que apenas o meio empresarial é capaz de produzir histórias em quadrinhos. Como também nos mostram que mesmo inseridos neste meio, os indivíduos são os principais responsáveis pela produção das histórias em quadrinhos, como fica claro nas narrativas três e quatro. Posto isso, é importante destacar a Arte de Quadrinizar neste processo, pois, permite aos envolvidos na atividade se inserirem no processo de construção do conhecimento escolar de geografia a se posicionar frente a realidade imposta pela colonialidade.

$\mathrm{Na}$ pergunta que diz respeito a qual visão de mundo a história em quadrinhos constrói tivemos: i) "Relacionada com a realidade"., ii) "Inclusão social, como exemplo as revistas da Turma da Mônica"., iii) "Conta uma história fictícia”., iv) “mesmo o que é dito como 'apenas entretenimento' possui política. Por exemplo o capitão américa era a personificação do patriotismo americano kkk", v) "Como um quadrinho é uma relação entre texto e imagem podem sempre existir nuances incríveis entre os dois. Claro a visão que o autor tiver ou quiser colocar”.

Os trechos destacados, nos mostram que apesar de estar bastante presente no cotidiano dos alunos, e, quando associados a ideia de geopolítica popular aqui debatida, as histórias em quadrinhos carregam consigo uma Cosmovisão que fortalece - como visto através da história do Tio Patinhas - as colonialidades aqui debatidas, ou uma visão de mundo que serve como resistência as mesmas - como o caso das histórias aqui analisadas de Marcelo D’Sallete, George Takai, e Por mais um dia com Zapata. 
Quando questionados sobre a relação das histórias em quadrinhos com o conhecimento escolar de geografia mostraram que é uma forma de se pensar este conhecimento para além dos mecanismo tradicionais mediados pela inter-relação das colonialidades debatidas no primeiro capítulo com as seguintes narrativas: i) "Método indireto de ensinar", ii) "Tem como associar a uma matéria", iii) “Aborda o conteúdo escolar de forma mais leve", iv) "Deixa uma maneira mais lúdica o conteúdo", v) "É uma leitura mais leve”, vi) "Quando aplicada no ensino, passa o conhecimento através de outra linguagem"., vii) "É uma tentativa de ser mais realista".. Mostrando que o conhecimento escolar de geografia pode ser produzido por outros meios que não sejam aqueles que acentuam cada vez mais as desigualdades sociais, sendo as histórias em quadrinhos um deles.

Na parte que diz respeito à análise do filme "Alô amigos", podemos ver as narrativas dos estudantes ao falar da relação entre Zé Carioca e Pato Donald: i) "Mostra um país sem conflito, totalmente pacífico. Resumindo tudo a festa"., ii) "Resume a cultura do Rio de Janeiro ao samba", iii) "Essa estereotipação faz muitas vezes a gente negar ou diminuir nossa cultura nacional", iv) "essa visão vem de um patriotismo americano descendente do eurocentrismo já que eles foram colônia da Inglaterra kkkkk [...] nós somos ensinados que nossa cultura é menos", v) "essa é uma visão de fora do Brasil [...] estereótipos puros kkk" (sobre o trecho do Zé Carioca), vi) "uma sociedade simples, sem problemas, sem conflitos" (sobre o trecho do Zé Carioca)", vii) "eles acham que simplesmente eles são melhores que todos, tem a melhor economia, e não tem que aprender sobre outros países porque eles estão acima dos outros" (sobre o trecho do Zé Carioca)", viii) "No vídeo eles mostram os estereótipos de cigarro, samba e praia. Mas mudou, por exemplo o filme Rio, que já trás os estereótipos de praia, samba e favela".

À vista disso, quando provocados a analisar o trecho do filme, podemos ver que os mesmos reconhecem, que a animação é uma ferramenta potente no que diz respeito a produção de uma visão de mundo sobre o sujeito latino-americano. Também, como podemos ver através da oitava narrativa, esta produção não é estática, mas se encontra em um constante processo de transformação.

Nas tirinhas da Mafalda tivemos nas primeiras as seguintes narrativas: i) "Reclamam do passado", ii) "Aprendem com o passado para não errar no futuro", iii) "crítica ao conhecimento", iv) "por exemplo; devemos deixar de bater na 
mesma tecla por muitos anos e dar espaço para outras matérias"., v) "Para entender o presente precisa entender o passado". Ao analisar as narrativas destacadas, podemos ver que se aproximam diretamente a ideia de decolonialidade debatida neste trabalho, pois, reconhece a necessidade de se criar novas narrativas e visões de mundo que rompam com o conhecimento construído através da inter-ralação da colonialidade do saber para com as colonialidades do poder e ser.

Já na segunda tirinha, as narrativas destacadas foram as seguintes: i) "existem brasileiros que odeiam o Brasil e querem ir embora. Não acredito que vocês nunca acharam alguém que fala que o nosso país é ruim e quer morar, POR EXEMPLO, nos estados unidos”, ii) “é o ‘sentimento patriota' de querer melhorar o país obviamente existem vários tipos de patriotismo, mas além da etimologia da palavra, existe o uso prático dela hoje em dia”, iii) "busca algo para se orgulhar"., iv) "Desde sempre ensinando que o outro é melhor.

Podemos ver até aqui que quando usada no ensino de geografia buscando construir um conhecimento geográfico decolonial, as histórias em quadrinhos se encontram presentes no cotidiano dos estudantes, aproximando-se com a ideia de conhecimento significativo debatido neste trabalho. Como também, como podemos ver através das narrativas, possui um conhecimento especializado que carrega consigo uma visão de mundo transformadora da realidade. No qual, o conhecimento pertinente, vem a ser os resultados alcançados através desse diálogo, e que serão expostos nas subseções a seguir.

\subsubsection{2}

\section{Gritos grupo A}

A seguir mostraremos os resultados alcançados com o grupo A. Ao todo foram sete produções: i) Desmatamento da Amazônia, ii) Queimadas, iii) Racismo, iv) Violência contra a mulher, v) invasão europeia.

Na primeira (Figura 10), podemos ver como não só o capital influencia no aumento do número das queimadas, sendo a televisão o lugar escolhido por este para fortalecer a visão de mundo imposta pelo significado ontológico do ano de 1492. Mostrando como a mídia influência de forma direta na construção de uma visão de mundo sobre determinado acontecimento ou conhecimento. 


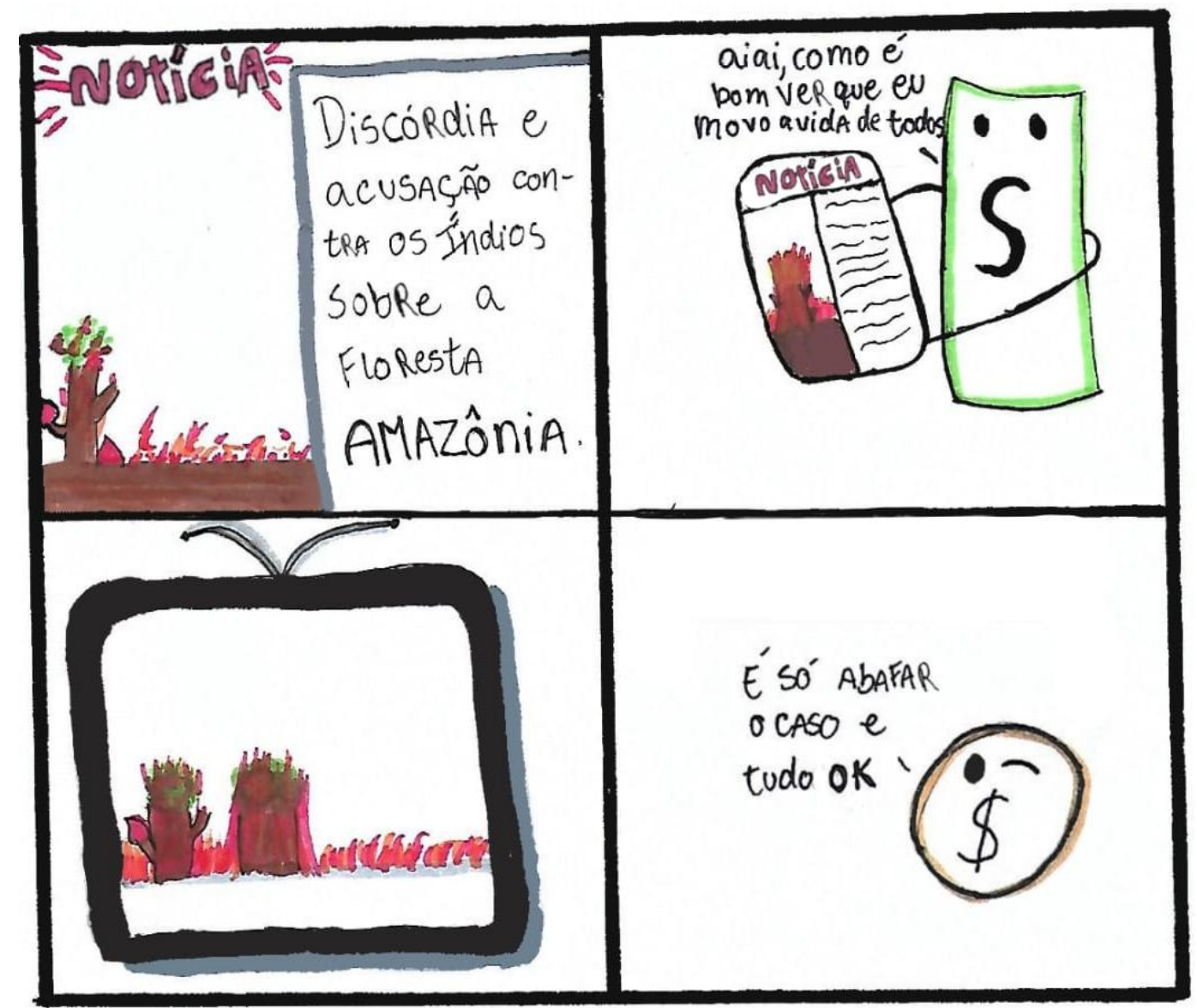

Figura 9 Impacto ambiental I

Na Figura 11, temos uma charge trazendo uma crítica ao discurso usado sobre o desmatamento da floresta, no qual reduz o desastre ambiental a um fato natural extremo. Entretanto, é importante destacar, que por mais que retratem o índio, podemos ver na cor usada que o mesmo é desenhado da cor branca. Mostrando traços e visão de mundo que é imposta pela inter-relação entre as colonialidades debatidas neste trabalho. 


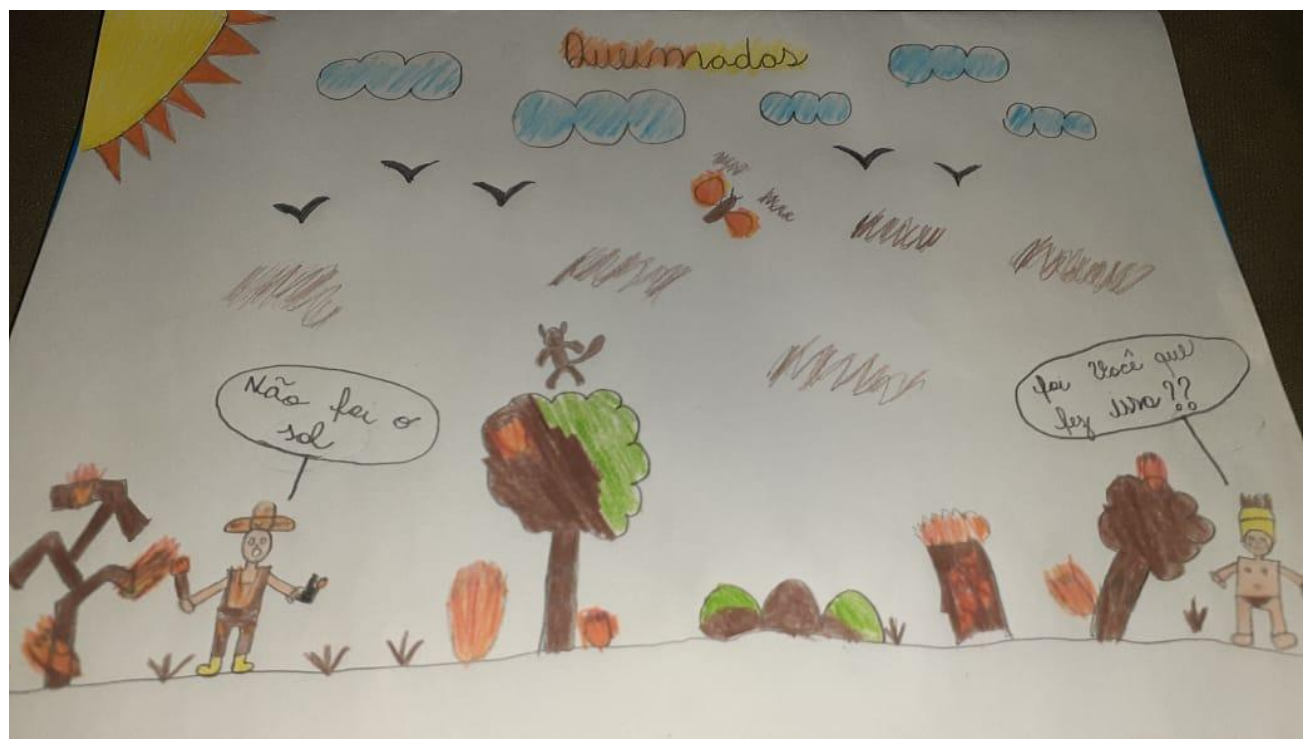

Figura 10 Impacto ambiental II

A Figura 12 fora retratada pelo grupo, no qual trazem uma cena do cotidiano para gritar sua indignação frente ao racismo presente na sociedade. Nos mostrando que através da cor da pele, associamos o indivíduo negro ao estereótipo de bandido. Associação que fica clara no quadrinho quando o rapaz negro ao ser parado pelo policial fala: "Como assim? Eu sou a vítima! Ele literalmente tá armado!”, e, tem como resposta do mesmo policial: “É óbvio que não é ele, sempre seu tipo é o culpado". Outro ponto a destacar é a importância que a tecnologia tem para conseguir acabar com esses casos de racismo, no qual na figura podemos ver que através de uma câmera identificam o ato discriminatório por parte do policial.

Logo, o fim da história, nos mostra que nada adianta a tecnologia, se os culpados não são realmente responsabilizados pelos seus atos. Indignação e grito que é expresso da seguinte forma: "No final, mesmo com tudo gravado, o policial não foi preso, já o menino inocente foi 2 " 


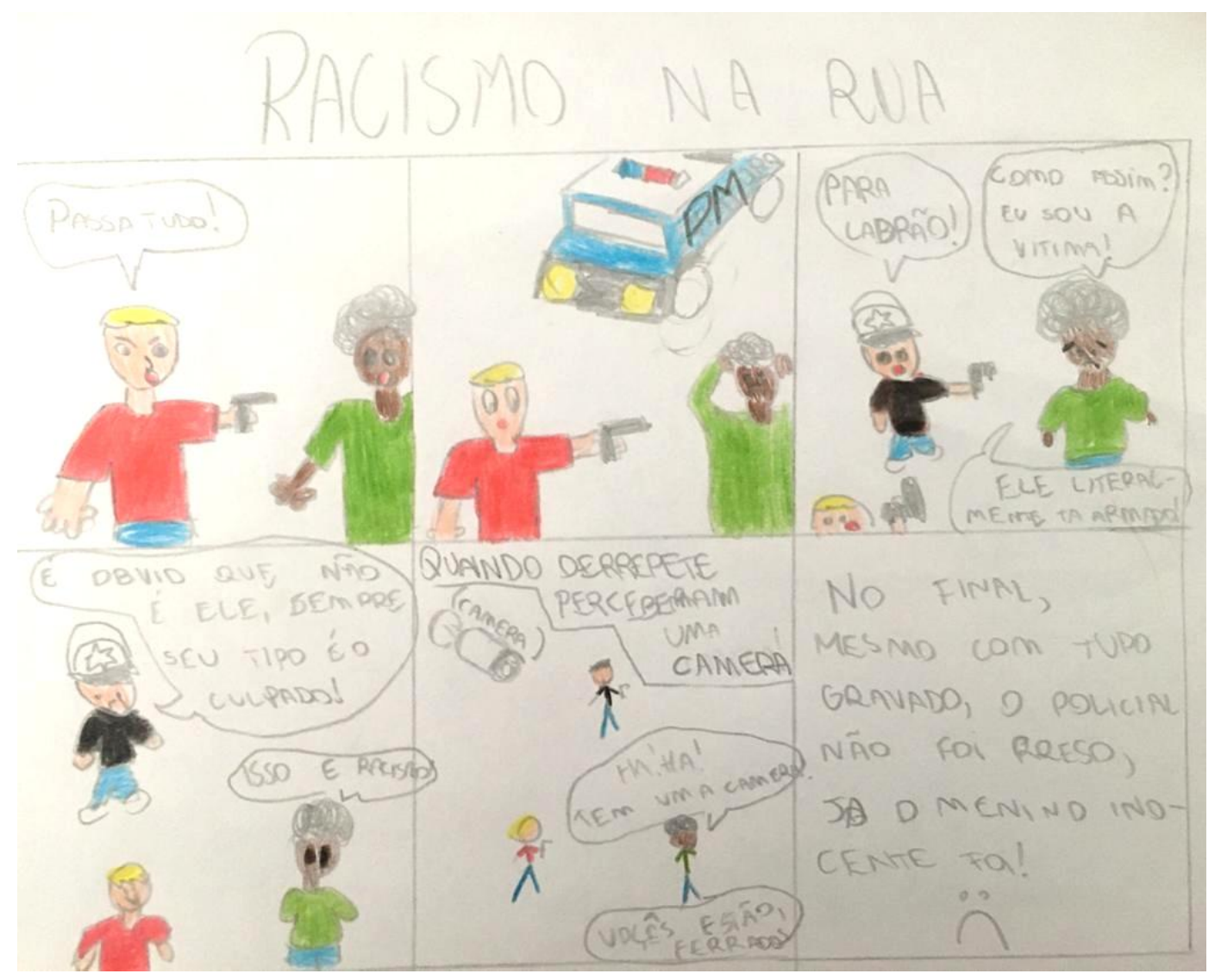

Figura 11 Racismo I

A Figura 13, traz uma situação muito comum também na sociedade: o racismo no ambiente de trabalho. Mostrando como agimos de forma racista, em sempre reduzir o negro a uma função dentro de algum ambiente de trabalho. Como forma de mostrar como isso se reflete na sociedade - no penúltimo quadrinho - vemos uma estatística mostrando como o racismo afeta a juventude negra brasileira, nos fazendo questionar sobre nossas ações cotidianas.

Como solução desta questão, o grupo traz uma frase usada em protestos anti-racista ao longo do globo nos últimos meses: “Black Lives Matter”. Não só pondo negros sendo representados, como também asiáticos. Outro ponto a destacar também é a forma como o chefe da empresa agiu na situação, desculpando o racista, mas punindo-o com a demissão. 


\section{Sem título}
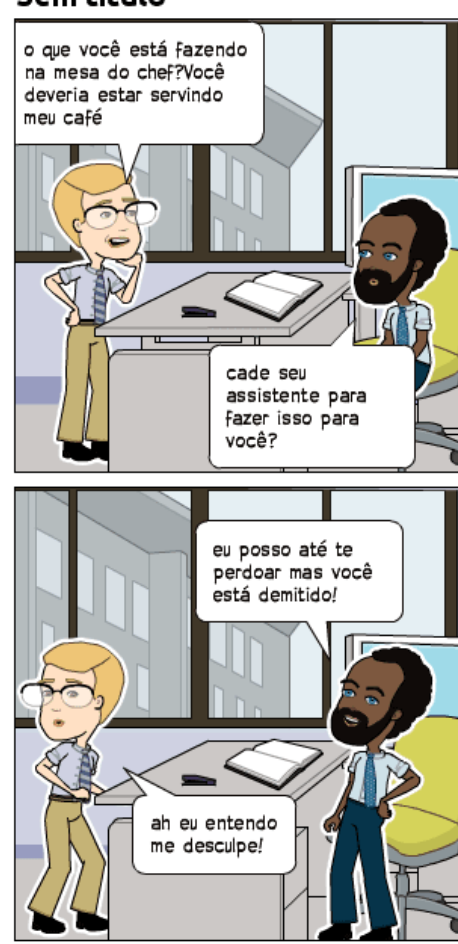

PIXTON
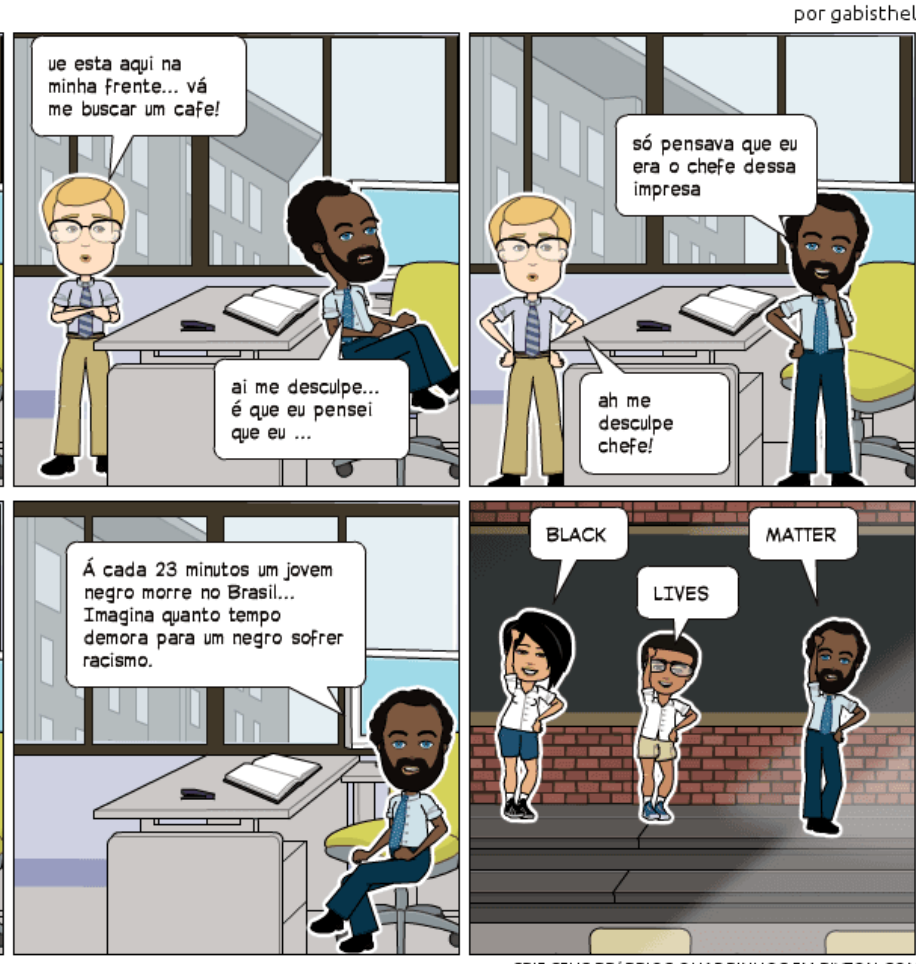

Figura 12 Racismo II

Na Figura 14, nos traz outro cotidiano bem comum na sociedade: a violência contra mulher. Neste caso é importante destacar dois elementos tragos pelo grupo: i) o uso da HQ como forma de propagar o número de violência contra a mulher, acompanhado da seguinte frase: "Denuncie a violência contra a mulher”, ii) após retratar uma cena de seu cotidiano, terminam a história em quadrinhos compartilhando de suas experiências cotidianas: "As mulheres não têm medo da força do homem. E não tem medo da luta. Forte e Guerreira como mamãe!". 


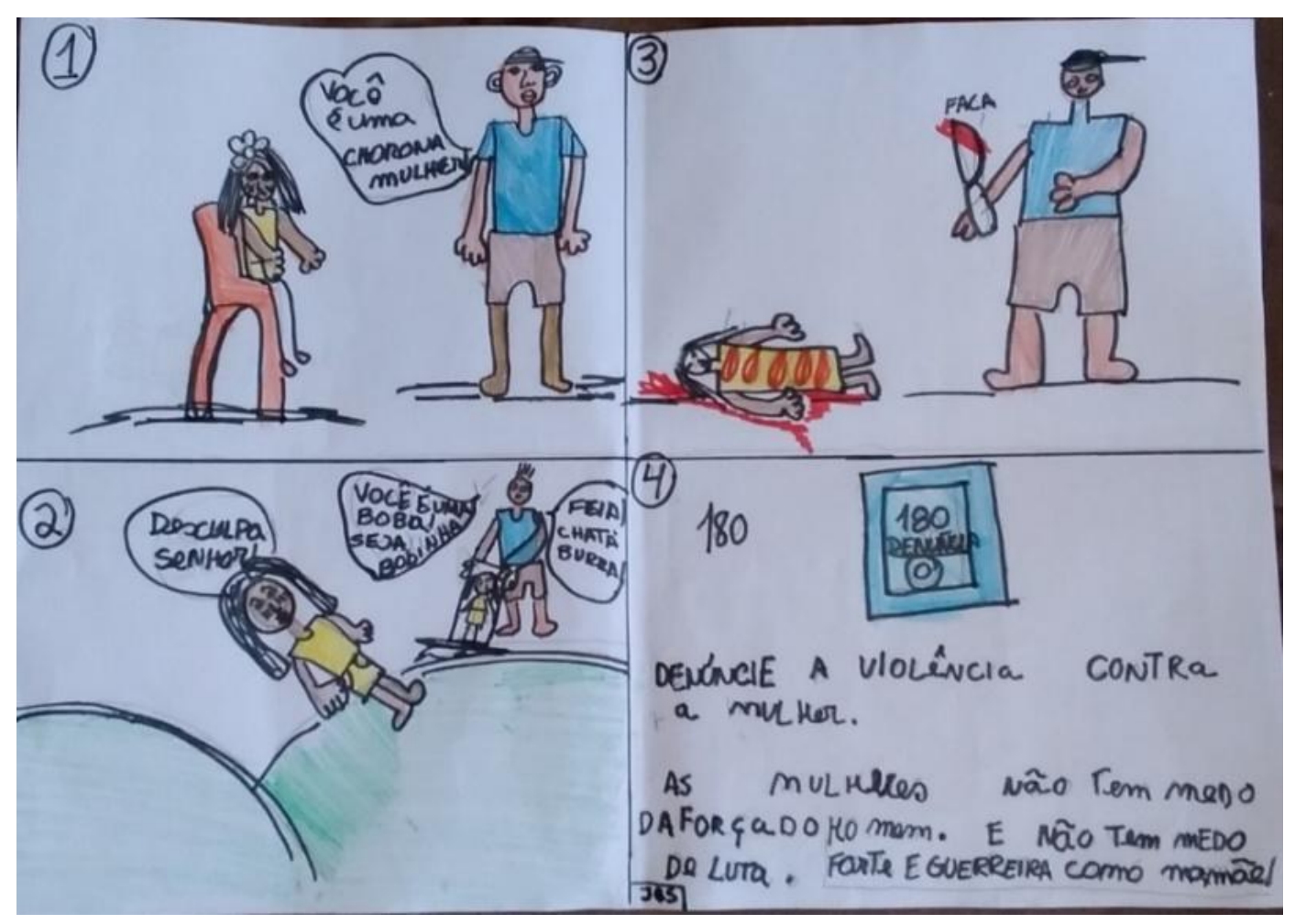

Figura 13 Violência contra a mulher

Na Figura 15, dois textos são importantes destacar, pois, vão de encontro direto com os debates feitos nos momentos anteriores da atividade pela forma como retratam a relação homem moderno x outro não moderno: "Vamos chegar e vamos conquistar, ensinar a viver a como se comportar e de quebra vamos pegar todas as pedras preciosas". \& “Conseguimos tiramos todas as preciosidades, estamos ricos, eles são tão pobres". Esses textos, vão de encontro direto, com o Mito da Modernidade debatido no primeiro capítulo. Porque como vimos, a Europa se põe como centro do mundo, conquistando e impondo uma visão de mundo frente ao outro não-europeu. 


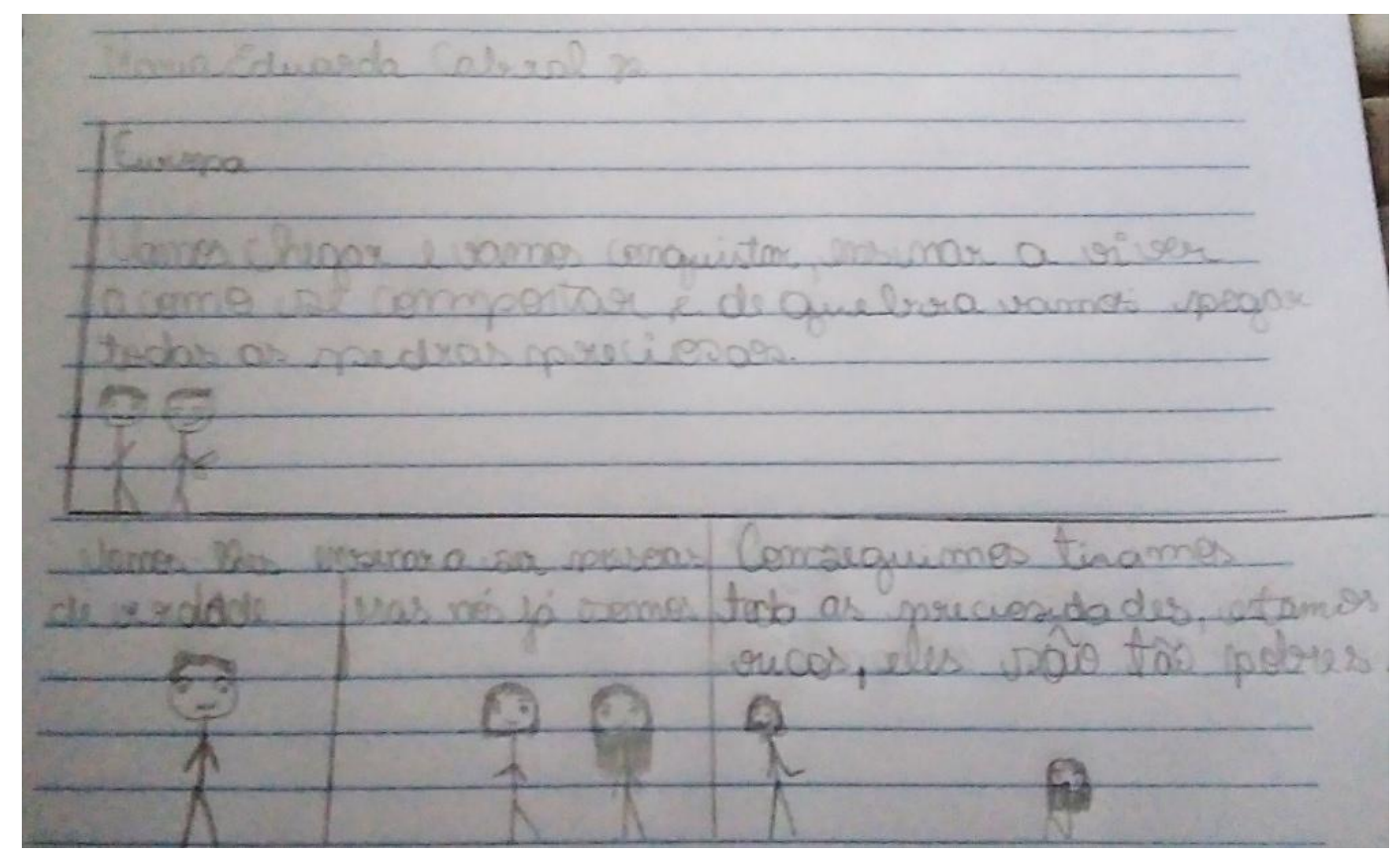

Figura 14 Invasão europeia

\subsubsection{3}

\section{Gritos grupo B}

Nesta subseção mostraremos os resultados alcançados com o grupo B. Ao todo foram sete produções com os seguintes temas: i) Racismo, ii) Pré-conceito no futebol, iii) Queimadas, iv) Precariedade do sistema público de saúde, v) Corrupção, v) Identidade.

Na figura 16, temos outra situação muito comum em nosso cotidiano; no qual uma vendedora branca de uma loja de grife, age de forma racista frente a cliente negra, associando sua cor de pele a seu aspecto financeiro. Duvidando até quando recebe o dinheiro, pois, como podemos ver na imagem, a mesma checa a nota para ver se é verdadeira, juntamente com uma fala que complementa sua atitude racista: "Será que tem mesmo???". 


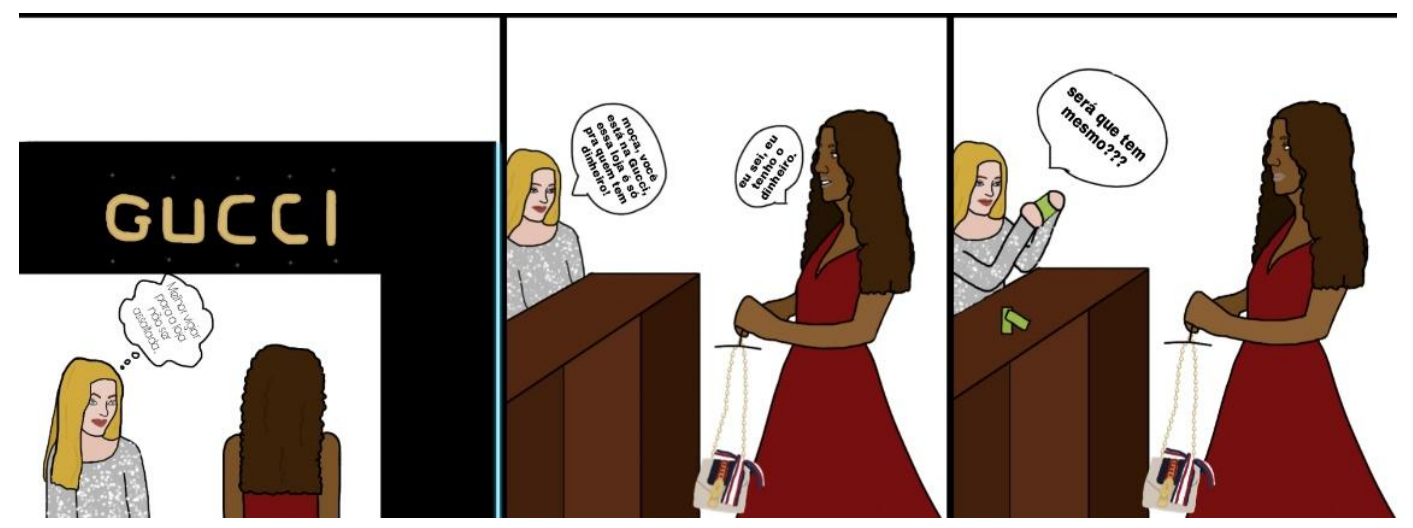

Figura 15 Racismo III

A imagem 17 traz como tema o preconceito no futebol. Destacando as dificuldades que a mulher tem de adentrar nesse espaço. No qual, como podemos ver através da produção textual, sua habilidade futebolística é inferiorizada pelo fato de ser mulher

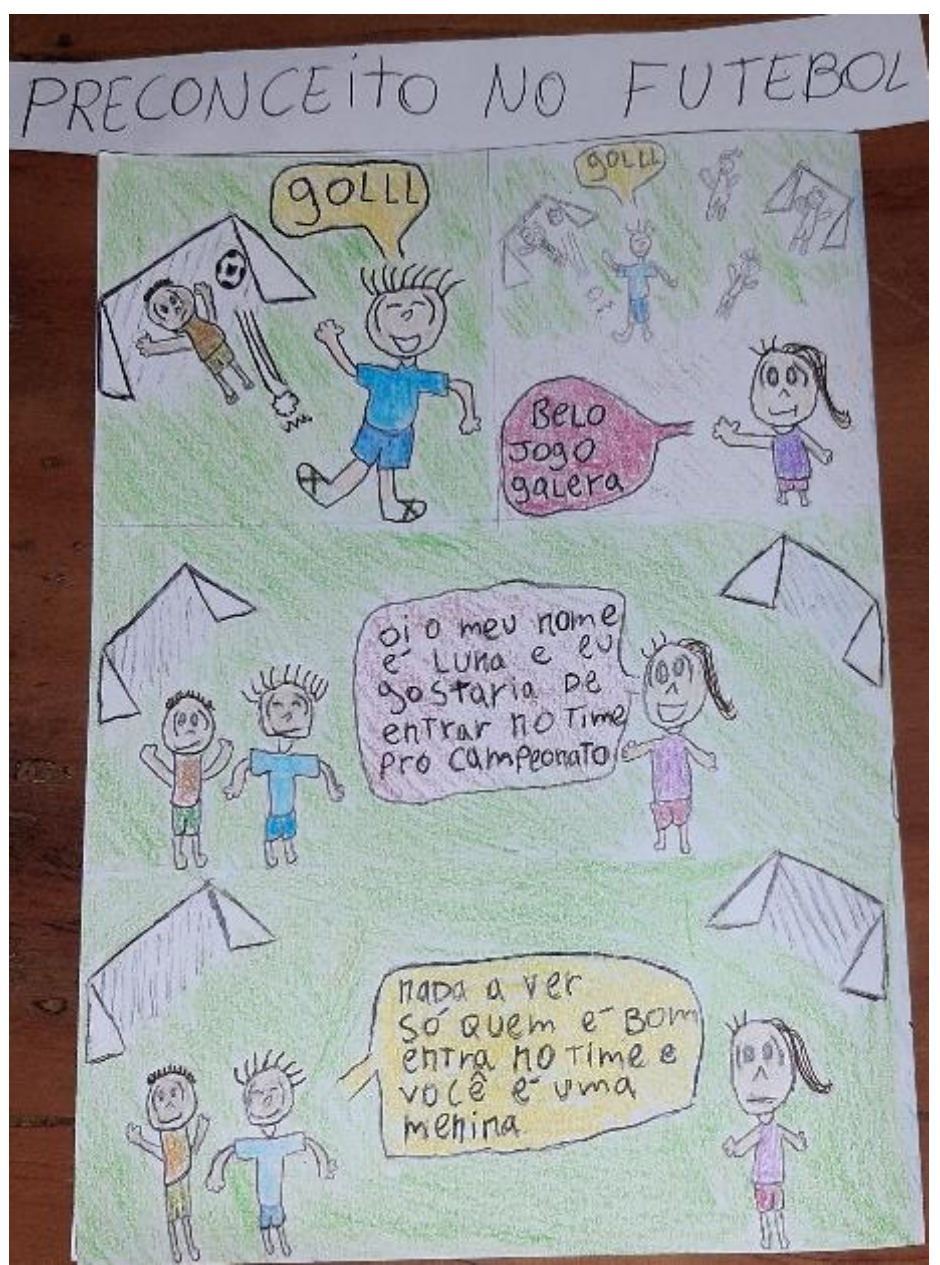

Figura 16 Pré conceito no futebol 
Na Figura 18, com o tema queimadas, temos o destaque para a construção da Cosmovisão através do discurso da mídia vs realidade. Dicotomia que fica clara com o animal, que no meio da queimada pergunta se alguém viu o jornal. Outro ponto a destacar desta dicotomia são os diferentes espaços representados na figura: i) um condomínio urbano qualquer e ii) a floresta em chamas, que são interligados pela mídia e sua informação.

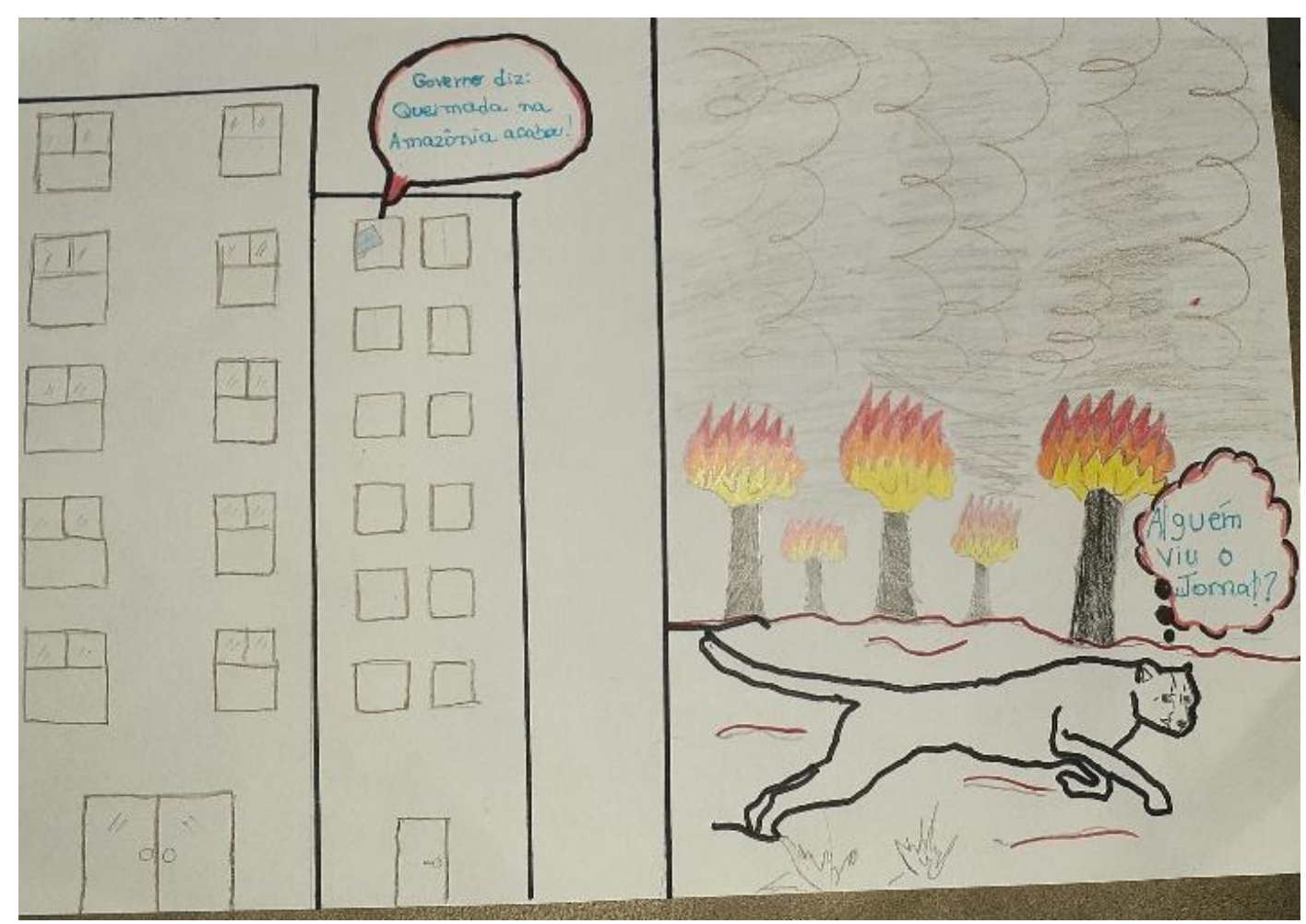

Figura 17 Impacto ambiental III

A Figura 19, nos traz um tema bem atual: a COVID-19. Fazendo uma crítica direta a precariedade do sistema público de saúde brasileiro no que diz respeito a demora dos resultados saírem. Essa demora é representada quando o personagem, fala com seu falecido avô: "Vô, saiu o seu teste de COVID pelo SUS". Outra crítica feita, é representada também na figura 20 , no que diz respeito a demora ao atendimento no SUS; i) quando a morte recepciona os pacientes da fila perguntando: “Quem é o próximo?", ii) a fala da personagem ao dizer: "Estou mais de 4 horas em pé”. 


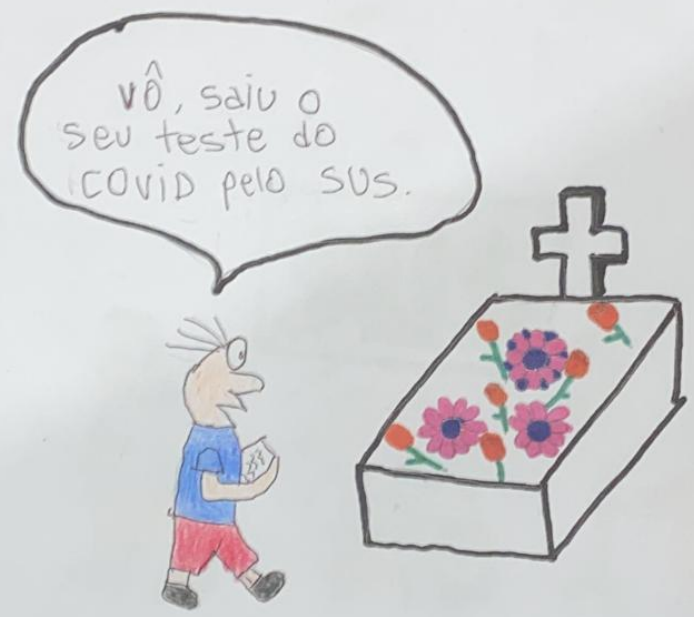

Figura 18 Precariedade do sistema de saúde público I

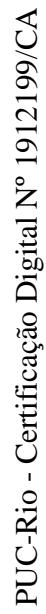
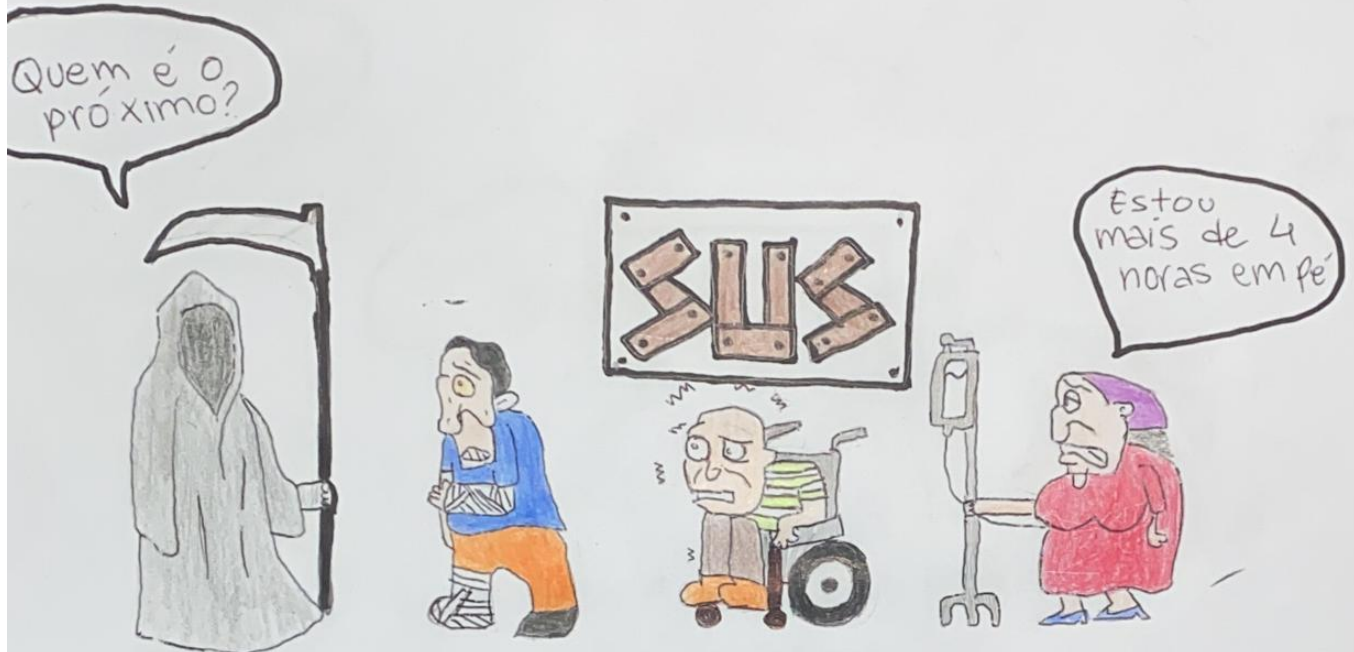

Figura 19 Precariedade do sistema de saúde público II 
A Figura 21, nos traz uma reflexão profunda sobre a construção da identidade. Quando uma menina, sem rosto, em frente ao espelho se questiona: "Quem sou eu?". Junto a este questionamento em um fundo negro ela se questiona: "não sou tão escura para ser aceita como negra", e, em um fundo branco: "nem tão clara para ser aceita como branca". Nos mostrando como a imposição de um padrão de cor impede que o indivíduo se reconheça frente a realidade que se encontra inserido.

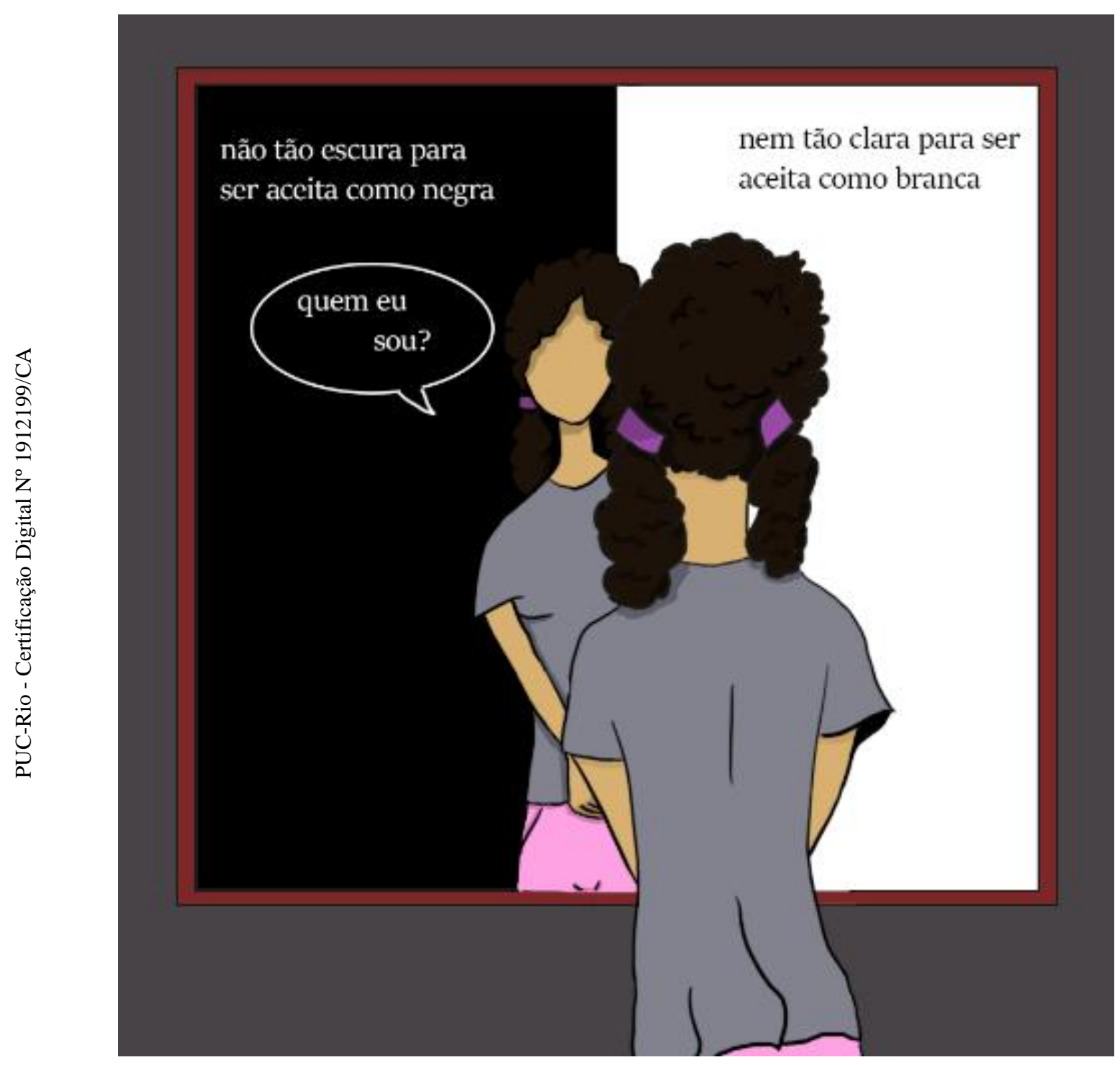

Figura 20 Identidade

Por fim, mas tão importante quanto a Figura 22, também viera abordar o racismo. No qual, uma cliente negra, pede uma meia "cor de pele". Com o pedido feito, o vendedor traz uma meia preta. Indignada com a situação a cliente fala: "Estas meias são pretas! Eu pedi cor de pele!". 


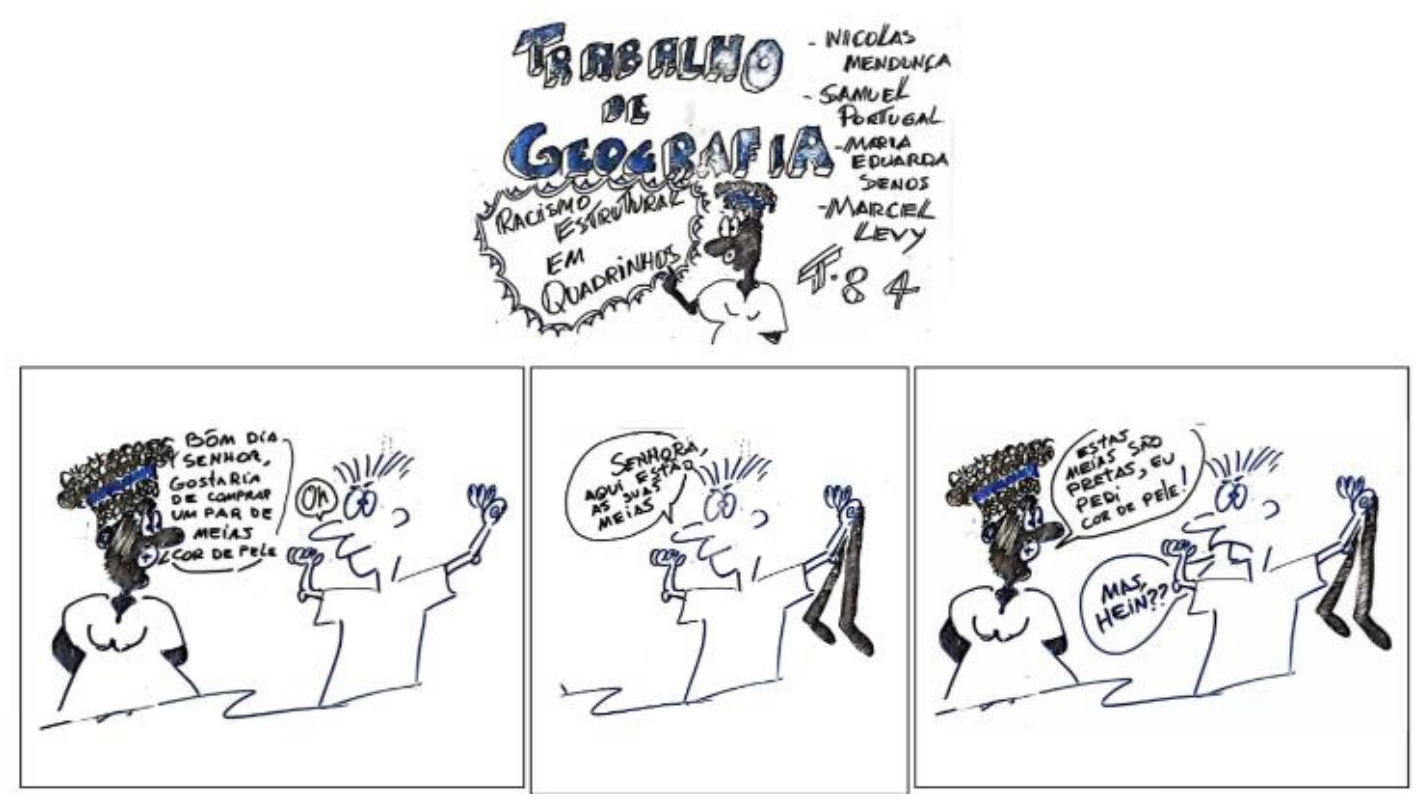

Figura 21 Racismo IV

\subsubsection{4}

\section{Resultados alcançados grupo A \& B}

Nas duas subseções que antecedem a esta, vimos os gritos dos estudantes frente a atividade proposta neste trabalho. Desta forma, nesta subseção iremos fazer uma aproximação entre as produções feitas pelos estudantes, para com o ensino de geografia decolonial exposto neste trabalho.

O primeiro ponto a destacar nos resultados alcançados é a criatividade dos estudantes. Trazendo histórias feitas por aplicativos, a mão, várias formas. Como também a própria escolha da estrutura das histórias em quadrinhos. Enquanto alguns alunos fizeram tirinhas com vinhetas ou não, outros optaram pelas charges.

Criatividade, que é um:

“É um fenômeno mental complexo, difuso e multifacetado, acessível a qualquer pessoa (RATO, 2009), que envolve diversas habilidades simples e algumas técnicas especializadas (ROBINSON, 2011), requer a confluência de seis recursos: habilidades intelectuais, conhecimento, estilos de pensamento, personalidade, motivação e ambiente (STERNBERG, 2006), e precisa de um clima de segurança para liberdade de expressão (BRIGGS, 2000) sendo fundamental em todas as áreas do conhecimento (RATO, 2009)". (GRINGON, 2014, p. 5). 
Logo, quando associamos a criatividade ao conhecimento escolar de geografia decolonial, por meio de uma atividade que não só encara as histórias em quadrinhos pela ótica da geopolítica popular, como também pela perspectiva da Arte de Quadrinizar. Encaramos o processo criativo do conhecimento escolar de geografia decolonial como um processo individual e coletivo. Onde através de uma introspecção (individual) nos "comunicamos e apresentamos ao contexto social nossas novas percepções” (RATO, 2009, p. 15) (coletivo).

Desta maneira, como destacado por Ribeiro (2011), o ato criativo dos estudantes na atividade elaborada fora encarado como uma realização que se encontra imersa em um contexto social, temporal, histórico e espacial, que tem seu crescimento potencializado por "atividades inusitadas, contrabalançando as atividades quotidianas, que as ajudem no protagonismo de suas vidas". (CALL \& FEATHERSTONE, 1995 apud GRINGON, 2014, p. 22).

Outro ponto importante a destacar foram os diferentes usos de ferramentas para produção das histórias destacadas: do uso de aplicativos de celular para produzir a história em quadrinhos, a escolha de vinhetas, a opção de escolher produzir uma charge ou tirinha. Assim sendo, podemos ver que a atividade desenvolvida para com os estudantes, provocou-os a ponto de explorar o universo produtivo das histórias em quadrinhos, permitindo-os gritar frente a realidade imposta.

Assim sendo, nesta parte da subseção através da análise dos temas escolhidos pelos grupos de estudantes (Gráfico 1), iremos mostrar como a atividade elaborada vai de encontro direto para pensarmos a construção do conhecimento escolar de geografia por meio da perspectiva da geopolítica popular e decolonial das histórias em quadrinhos. 


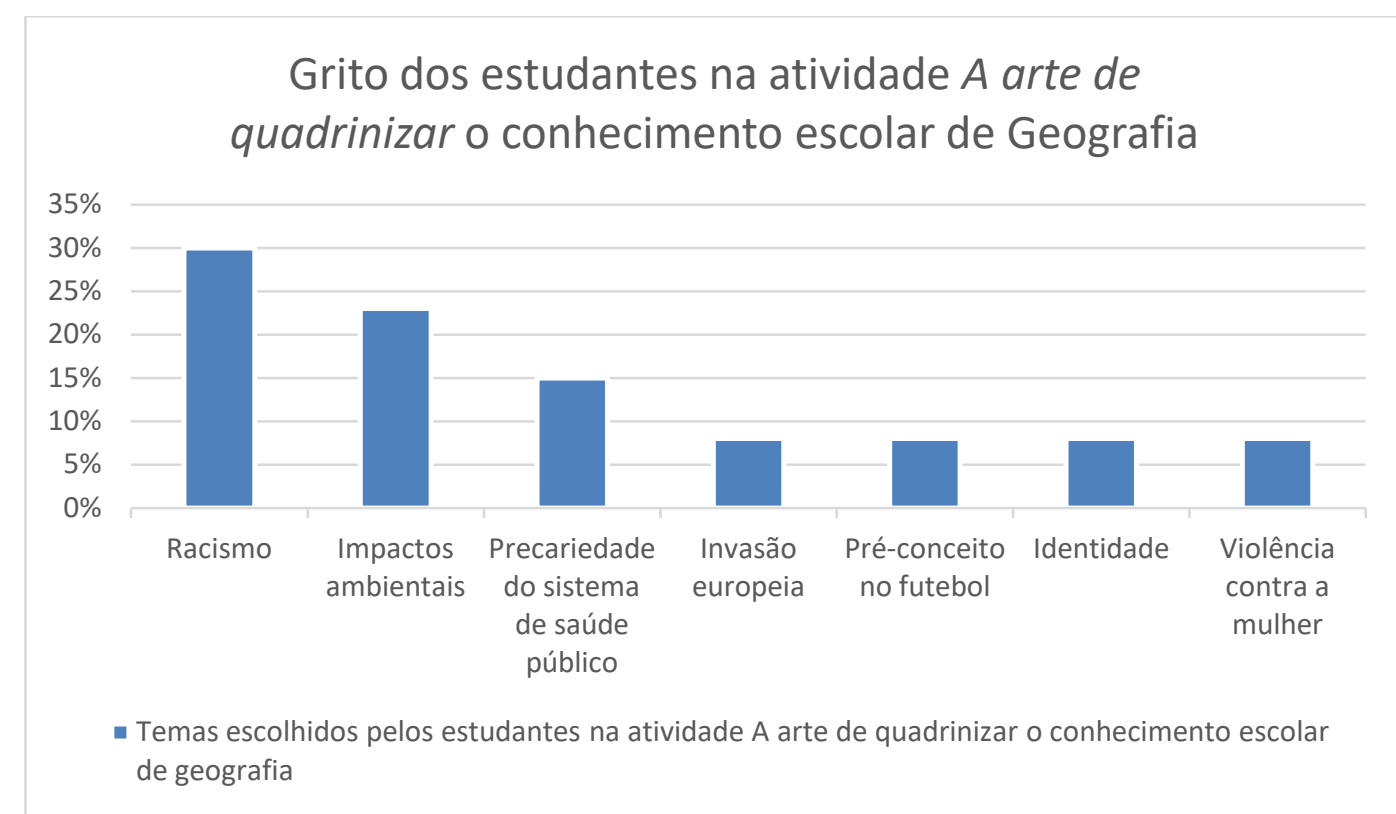

Gráfico 1 Grito dos estudantes na atividade A arte de quadrinizar o conhecimento escolar de Geografia

Porque ao analisar os dados do Gráfico 1, observamos que os temas escolhidos pelos grupos nos permite "repensar os significados que podem ser atrelados aos conceitos dos quais somos reprodutores". (MARIA, 2018, p. 86).

Isto é possível, pois, ao repensar os significados nos permitimos a:

Não devemos encarar o futuro como algo que está fechado, delimitado por esta "narrativa única" (civilização capitalista ocidental), como também, não podemos desconsiderar as circunstâncias e contingências que não determinam o ponto de chegada, mas, pertencem ao caminho bem como constroem-se junto a ele - as tramas de relações onde a vida se desenrola. (MARIA, 2018, p. 91).

Construção, que fica nítida nas narrativas expostas dos estudantes na parte da atividade referente a análise das tirinhas da Mafalda. Como visto, Miguelito amigo da Mafalda - desabafa com a mesma sobre o tipo de conhecimento construído na escola. E quando questionado pela protagonista qual seria a história que queria que contassem na escola; o personagem esbraveja: "Para frente!".

Ao analisar a tirinhas pela ótica das narrativas dos estudantes, nos mostram que os mesmos também consideram a importância da construção do conhecimento escolar de forma a proporcionar os envolvidos no processo de ensino aprendizagem a repensar as narrativas existentes de forma a considerar outras visões de mundo na construção da sociedade. 
Considerações que ficam nítidas através dos temas escolhidos pelos grupos expostos no gráfico. Nos mostrando, que ao construir o conhecimento escolar de geografia por meio da inter-relação entre: decolonialidade, geopolítica popular, os conhecimentos expostos no capítulo três e do uso das histórias em quadrinhos pela perspectiva da Arte de Quadrinizar. Se cria a possibilidade de construir não só um conhecimento como também uma visão de mundo que permite aos envolvidos no processo de ensino e aprendizagem de geografia a se posicionar frente a realidade que lhe é imposta, de forma a se tornar agente e sujeito de sua realidade.

Posto isso, ao usar A Arte de Quadrinizar como uma alternativa de construção teórica e prática do conhecimento escolar de geografia, pela ótica do Giro Decolonial e da Geopolítica Popular e dos conhecimentos citados no capítulo três, constrói-se um conhecimento escolar de geografia que se encontra diretamente relacionado à "um processo incessante onde reflexão, ação e reflexão sobre a ação estão dialeticamente ligadas". (WALSH, 2014, p. 92).

Ligação que permite a construção de um conhecimento escolar de geografia que "possibilita e constrói maneiras outras de ser, estar, pensar, saber, sentir, existir e viver com" (WALSH, 2017, p. 2). Sendo construído:

de formas diferentes dentro das próprias lutas, como necessidade de sustentar e compreender criticamente o que está sendo enfrentado, contra o que deve ser resistido, elevado e agir, com quais visões e horizontes diferentes, e com quais práticas e insurgências pró-ativas de intervenção, construção, criação e libertação. (WALSH, 2017, p. 59).

Construção que fica nítida através da produção dos grupos. Como exemplos a destacar temos as Figuras 13 e 14. Na Figura 13, a forma como o grupo compreendeu criticamente o que estava sendo enfrentado, foi a aceitação de narrativas e ações do cotidiano como práticas que se encontram diretamente associadas as colonialidades debatidas no primeiro capítulo. No qual a resistência se encontra associado a romper com as práticas e pensamentos racistas existentes não só no mundo coorporativo, como retratam, como também na sociedade. Sendo a intervenção a exposição do problema, que tem como solução um tratamento que não trata o racista como vítima, mas sim como culpado.

Por sua vez, na Figura 14, a maneira que o grupo compreendeu o que estava sendo enfrentado, foi também a aceitação presença da colonialidade em seu cotidiano. Sendo a resistência, a forma como desenvolvem a história em 
quadrinhos ao abordar o tema de violência contra a mulher. No qual a intervenção vem através da exposição do número 180 de denúncia de violência contra a mulher, junto a frase: "As mulheres não têm medo da força do homem. E não tem medo de luta. Forte e guerreira como mamãe!’.

Aceitação, resistência e intervenção que são "um grito frente ao sistema capitalista-extrativista-patriarcal-moderno/colonial” (WALSH, 2017, p. 76). Aceitação, resistência e intervenção frente ao sistema capitalista moderno/colonial como podemos ver através da Figura 15, quando o grupo retrata a invasão europeia em terras latino-americanas. Aceitação, resistência e intervenção frente ao sistema extrativista, como pode ser visto nas Figuras 10 e 18, quando os estudantes gritam mostrando a influência da mídia no processo de construção de visões de mundo sobre as queimadas. Aceitação, resistência e intervenção frente ao sistema patriarcal, que fica nítido na Figura 14.

Posto isso, podemos ver com a atividade desenvolvida a construção de um "conhecimento subordinado que é produzido no contexto das práticas de marginalização" (WALSH, 2017, p. 89). Conhecimento, como podemos ver não só construído através dos temas escolhidos pelos grupos, como também através de suas produções e reivindicações que tem como objetivo a construção "de um pensamento crítico que tem em seu lugar transformações radicais e a criação de novos arranjos sociais ou ordenamentos [...] para toda a sociedade". (WALSH, 2007, p. 231). 


\section{6 \\ Considerações finais}

Ao usar a ótica da geopolítica popular associada ao Giro Decolonial, mostramos através da análise das histórias em quadrinhos - "Cumbe" (2018), "Angola Janga" (2017) \& "Por mais um dia com Zapata" (2015) - como as mesmas "influenciam a percepção geopolítica [...] com formatos de resistência" (HOLLAND, 2012, p. 111-112).

Construindo não só Cosmovisões alternativas da geopolítica, como é destacado por Holland (2012), como também um conhecimento geográfico capaz de "reinterpretar a palavra mito e a escrita da Terra, de maneira que essa "escrita" possa comportar uma leitura nova". (DARDEL, 2015, p. 65). Criador de possibilidades que permitem que o conhecimento geográfico seja construído de forma exterior ao conhecimento e realidade imposto pela inter-relação das colonialidades destacadas no primeiro capítulo.

Conhecimento geográfico que ao ser produzido através da inter-relação da geopolítica popular para com o Giro Decolonial, como visto no primeiro capítulo, é construído por meio de "produtos culturais de oposição [...] que influenciam a percepção geopolítica [...] com formatos de resistência". (HOLLAND, 2012, p. 111-112). Reconhecedor de diferentes tipos de práticas alternativas que "não geram só uma busca pela reinterpretação explícita entre espaço e poder, mas uma demanda pela descolonização do pensamento e saberes que envolvem a compreensão do espaço" (PRECIADO CORONADO, 2010, p. 70).

Como forma de se pensar esses sabres trouxemos neste trabalho as histórias em quadrinhos, pois, como visto no primeiro capítulo através das histórias analisadas, são responsáveis pela construção de narrativas que perturbam e desafiam "as narrativas dominantes que justificam visões hegemônicas" (HOLLAND, 2012, p. 108), de forma que a geopolítica popular permite que sua produção comporte uma visão de mundo que se encontra exterior a visão de mundo e conhecimento imposto pelas colonialidades destacadas no primeiro capítulo. No qual o conhecimento geográfico produzido reconhece os "processos geográficos e relações geopolíticas a diversas escalas e com uma diversidade de sujeitos visualizados ou não por discursos dominantes”. (PRECIADO CORONADO, 2010, p. 86). 
Ao reconhecer esta potencialidade da história em quadrinhos, se criam possibilidades não apenas para a produção de um conhecimento geográfico acadêmico, como também a construção de um conhecimento escolar de geografia que reconhece outras "formas de ser, pensar e conhecer diferentes da modernidade europeia, porém em diálogo com esta”. (MIGNOLO, 2003 apud OLIVEIRA; CANDAU, 2010, p. 23). Sujeitando constantemente o conhecimento escolar de geografia hegemônico a questionamentos "na medida em que questiona os referenciais eurocêntricos”. (PENNA, 2014, p. 183).

Como forma de pensar teoricamente o uso das histórias em quadrinhos para se pensar um conhecimento de geografia decolonial, no terceiro capítulo através da análise das histórias em quadrinhos [por Tio Patinhas e história do George Takai com nome certo], vimos que as mesmas criam - segundo Gomes e Góis (2008) - cria ações sequenciais que se encontram inseridas em um tempo-espaço produtor de significados que representam o sentido de determinado lugar. Permitindo assim a (re)construção de significados variados, e, que revelam cenários e ações do lugar representado, que concebe o espaço - como visto através das narrativas de George Takei e arte de Harmony Becker - como uma dimensão que serve de instrumento "tanto de percepção como de compreensão do mundo em uma visão tridimensional, e não apenas como ilustrações" (MENDONÇA; REIS, 2016, p. 64).

Reconstrução que através do uso no quinto capítulo das histórias em quadrinhos pelas perspectivas da geopolítica popular, giro decolonial, e, aproximação entre aprendizagem significativa com o conhecimento poderoso, nos mostrou que permite aos estudantes se posicionarem no espaço que estão inseridos, de forma a questionar a realidade imposta pelas colonialidades do ser, saber e poder. Posicionamento que é possível através do uso crítico da mídia história em quadrinhos, permitindo assim a criação de possibilidades poderosas e transformadoras da realidade que os envolvidos no processo de ensino aprendizagem de geografia se inserem como sujeitos e agentes transformadores de suas realidades.

Deste modo, A Arte de Quadrinizar, como visto no último capítulo, ao ser aplicada no ensino de geografia através das perspectivas da geopolítica popular, giro decolonial, conhecimento poderoso, significativo e pertinente; permite aos envolvidos no processo de ensino aprendizagem de geografia a construção de um 
conhecimento escolar oriundo de um processo "incessante onde a reflexão, ação e reflexão sobre a ação estão dialeticamente ligadas". (WALSH, 2014, p. 92).

Processo, como visto na atividade aplicada junto aos alunos do CAPUERJ, constrói um conhecimento escolar de geografia formado por diferentes formas de "ser, estar, pensar, saber, sentir, existir e viver com" (WALSH, 2017, p. 2). Sendo expresso através de gritos que enfrentam o conhecimento escolar construído através de uma visão de mundo criada pelo "sistema capitalistaextrativista-patriarcal-moderno/colonial" (WALSH, 2017, p. 76). Transformandoo em um conhecimento escolar de geografia que tem "em seu lugar transformações radicais e a criação de novos arranjos sociais ou ordenamentos [...] para toda a sociedade”. (WALSH, 2017, p. 231)

Destarte, o conhecimento de geografia escolar ao ser pensado e praticado através da inter-relação entre A Arte de Quadrinizar para com as perspectivas do giro decolonial, geopolítica popular, conhecimento poderoso, significativo e pertinente; proporciona aos envolvidos no processo de ensino aprendizagem a construção de um conhecimento escolar de geografia que enxerga e entende as relações de poder presentes na sociedade, e, que foram expostas através da ideia de colonialidade debatida no primeiro capítulo. Como também permite os envolvidos a se posicionarem frente a sua realidade como sujeitos e agentes transformadores da mesma. 


\section{Referências}

DISNEY, Walt. Febre do ouro. Coleção Disney Temático. São Paulo: Abril, 2014.

BARROS, João. Geopolítica del conociimiento: control de la subjetividade y del conocimento en la descolonialidad epistémica. In: Revista de Ciências Sociais, Fortaleza, v. 50, n. 2, jul/out, 2019, p. 31-50.

BERNSTEIN, Basil. A pedagogização do conhecimento: estudos sobre recontextualização. Tradução Maria de Lourdes Soares e Vera Luiza Visockis Macedo. In: Cadernos de Pesquisa, n. 120, p. 75-110, nov. 2003.

BESSE, Jean-Marc. Geografia e existência a partir da obra de Eric Dardel. In: DARDEL, Eric. O homem e a terra: natureza da realidade geográfica. Tradução Werther Holzer. São Paulo: Perspectiva, 2015.

BÉVORT, Evelyne; BELLONI, Maria Luiza. Mídia-educação: conceitos, história e perspectivas. In: Revista Educação \&amp; Sociedade. Campinas, v. 30, n. 109, p. 1081-1102, set/dez, 2009.

BORGES, Felipe da Rocha; FARIAS, Juliana Felipe. Um estudo sobre transformações socioespaciais, aprendizagem significativa e ensino de geografia em uma escola no distrito de Pecém - São Gonçalo do Amarante - CE. In: Revista de Ensino de Geografia, Uberlândia, v. 3, n. 4, p. 55-68, jan/jun 2012. BUDAI, Gilberto et al. Tecnologia como metodologia de ensino em geografia no ensino médio. In: Revista Científica UNAR, Araras (SP), v. 16, n. 1, p. 14-20, 2018.

CALDAS, Graça. Mídia, escola e leitura crítica do mundo. In: Revista Educação \&amp; Sociedade. Campinas, v. 27, n. 94, p. 117,130, jan/abr, 2006.

CARVALHO, Wander Guilherme; ARAÚJO, José Augusto Faria. Mídias locativas e realidade aumentada: potencialidades para o ensino geografia na cibercultura. In: ENANPEGE [Encontro Nacional da Associação Nacional de Pós-Graduação em Geografia]. Porto Alegre/RS, out. 2017.

CECEÑA, Ana Esther. Uma versão mesoamericana da América Latina. In: NOVAES, Adauto (organizador). Oito visões da América Latina. São Paulo: Senac São Paulo, 2006.

CHAUÍ, Marilena. Simulacro e poder. São Paulo: Editora Fundação Perseu 
Abramo, 2006, p. 5-78.

Cultura e democracia. Em: Crítica y emancipación: revista latinoamericana de ciências sociais. Año 1, n. 1, jun. Buenos Aires: CLASCO, 2008.

CRUZ, Valter do Carmo. Geografia e pensamento descolonial: notas sobre um diálogo necessário para a renovação do pensamento crítico. In: CRUZ, Valter do Carmo, OLIVEIRA, Denílson Araújo de. Geografia e giro descolonial: experiências, idéias e horizontes de renovação do pensamento crítico. 1. ed. Rio de Janeiro: Letra Capital, 2017.

DARDEL, Eric, 1899-1967. DARDEL, Eric. O homem e a terra: natureza da realidade geográfica. Tradução Werther Holzer. São Paulo: Perspectiva, 2015. DIÓRIO, Ana Paula Inacio; RÔÇAS, Giselle. As mídias como ferramenta pedagógica para o Ensino de Ciências: uma experiência na formação de professores de nível médio. In: Revista Práxis, Ano V, n. 10, dez. 2013. DODDS, Klaus. Enframing Bosnia: the geopolitical iconography of Steve Bell In: Rethinking Geopolitics. Edited by Gearóid Ó Tuathail and Simon Dalby. Taylor\&amp;Francis e-Library, 2002, p. 170-198.

Popular geopolitics and cartoons: representing power relations, repitition and resistance. In: Critical African Studies, Issue 4, December 2010, p.113-131. DORFMAN, Ariel; MATTELART, Armand. Para ler o Pato Donald: comunicação de massa e colonialismo. 6. ed. São Paulo: Paz \&amp; Terra, 2010. D’SALETE, Marcelo. Angola Janga: uma história de Palmares. São Paulo: Veneta, 2017.

Cumbe. São Paulo: Veneta, 2018.

DUSSEL, Enrique D. Filosofia da libertação na américa latina. 2. ed. São Paulo: Loyola. Piracicaba: UNIMEP (co-edição), 1977.

. Paulo de Tarso na filosofia política atual e outros ensaios. Tradução de Luiz Alexandre Solano Rossi. Coleção Novos caminhos da teologia. São Paulo: Paulus, 2016.

Transmodernidade e interculturalidade: interpretação a partir da filosofia da libertação. In: Revista Sociedade e Estado. V. 31, n. 1, jan./abr., 2016 b. EISNER, Will. Quadrinhos e arte sequencial. 3. ed. São Paulo: Martins Fontes, 1999.

Narrativas Gráficas de Will Eisner. Tradução de Leandro Luigi Del 
Manto. São Paulo: Devir, 2005.

FANON, Franz. Pele negra, máscaras brancas. Tradução de Renato da Silveira.

Salvador: EDUFBA, 2008.

FERRARA, Lucrécia D'Aléssio. Cidade e imagem: entre aparências,

dissimulações e virtualidades. In: Revista fronteiras - estudos midiáticos, VI(1):

21-32, janeiro/junho, 2004.

FISCHER, Rosa Maria Bueno. Mídia, máquinas de imagens e práticas

pedagógicas. In: Revista Brasileira de Educação, V. 12, n.35, maio/ago, 2007.

FREIRE, Paulo; GUIMARÃES, Sérgio. Educar com a mídia: novos diálogos sobre educação. São Paulo: Paz e Terra, 2011.

Professor sim, tia não: cartas a quem ousa ensinar. 26. ed. São Paulo:

Paz \&amp; Terra, 2016.

Educação como prática de liberdade. 8. ed. Rio de Janeiro: Paz e

Terra, 1978.

; GUIMARÃES, Sérgio. Aprendendo com a própria história. São Paulo:

Paz \&amp; Terra, 2011.

; SHOR, Ira. Medo e ousadia - o cotidiano do professor. Tradução de

Adriana Lopez; revisão técnica de Lólio Lourenço de Oliveira. Rio de Janeiro:

Paz \&amp; Terra, 1986.

A importância do ato de ler: em três artigos que se completam. São

Paulo: Autores Associados: Cortez, 1983.

Pedagogia do oprimido. 63. ed., Rio de Janeiro/São Paulo: Paz \&amp;

Terra,

2017.

Pedagogia da tolerância. 2. ed. Rio de Janeiro: Paz \&amp; Terra, 2014.

FERRERA-BALANQUET. Pedagogías creativas insurgentes. In: Pedagogias

decoloniales: Prácticas insurgentes de resistir, (re)existir y (re)vivir. Tomo II.

Série pensamento decolonial, Ediciones Abya-Yala - $1^{\text {a }}$ ed., Quito-Ecuador, 2017, p. $445-465$.

GIROTTO, Eduardo Donizeti; SANTOS, David Augusto. A geopolítica e o ensino de geografia: estratégias didáticas para a retomada do diálogo. In:

Geografia Ensino \&amp; Pesquisa, v. 15, n. 3, set/dez, 2011

GOMES, Paola Basso Menna Barreto. Mídia, imaginário de consumo e educação.

In: Educação \&amp; Sociedade, ano XXII, n. 74, abril/2001. 
GOMES, Paulo César da Costa; DE GÓIS, Marcos Paulo Ferreira. A cidade em quadrinhos: elementos para a análise da espacialidade nas histórias em quadrinhos. In: Revista Cidades, Presidente Prudente - São Paulo, v. 5, n. 7, jul/dez, 2008.

GOTTMANN, Jean. A evolução do conceito de Território. In: Boletim campineiro de geografia. V. 02, n. 03, 2012.

Doutrinas Geográficas na Política. In: Les doctrines politiques modernes. Nova York: Brentano’s Inc. - 586 Fifth Avenue, 1947.

GRINGON, Thiago Louis. Interfaces neurocientíficas entre criatividade, motivação e fobia criativa. Centro Universitário das Faculdades Metropolitanas Unidas, São Paulo, 2014.

GROSFOGUEL, Ramón. Para descolonializar os estudos de economia política e os estudos pós-coloniais: transmodernidade, pensamento de fronteira e colonialidade global. In: Revista crítica de ciências sociais, 80, mar. 2008. GUIMARÃES, Iara. Ensino de Geografia, mídia e produção de sentidos. In: Terra Livre, Presidente Prudente, ano 23, V. 1, n. 28, p. 45-66, jan-jun/2007. HARAWAY, Donna. Saberes localizados: a questão da ciência para o feminismo e o privilégio da perspectiva parcial. Cadernos pagu (5), 1995, p. 7-41. HOLLAND, Edward C. "To think and imagine and see differently": popular geopolitics, graphic narrative, and Joe Sacco's “Chechen war, chechen women”. In: Geopolitics, V. 17, Taylor \&amp; Francis Group, LLC, p. 105-129; 2012. HOLZER, Werther. A geografia fenomenológica de Eric Dardel. In: O homem e a terra: natureza da realidade geográfica. Tradução Werther Holzer. São Paulo: Perspectiva, 2015.

HEMMING, John. Os índios do Brasil em 1500. In: História da América Latina Colonial. Organização Leslie Betheli; tradução Maria Clara Cescato. 2. ed. V. I, 4. Reimpr. São Paulo: Universidade de São Paulo; Brasília: Fundação Alexandre de Gusmão, 2018.

KELLNER, Douglas; SHARE, Jeff. Educação para a leitura crítica da mídia, democracia radical e reconstrução da educação. Educ. Soc., Campinas, v. 29, n. 104 - Especial, p.687-715, out, 2008.

KROEF, Ada Beatriz Gallicchio; CORAZZA, Sandra Mara. Currículo-nômade: sobrevoos de bruxas e travessias de piratas. In: Programa de pós-graduação, Faculdade de Educação Universidade Federal do Rio Grande do Sul, Porto 
Alegre, out. 2003.

LESTEGÁS, Francisco Rodríguez. Concebir la geografia escolar desde una nueva perspectiva: una disciplina al servicio de la cultura escolar. In: Boletín de la A.G.E. No 33, 2002.

LIBÂNEO, José Carlos. Cultura jovem, mídias e escola: o que muda no trabalho dos professores? In: Revista Educativa, Goiânia, v.9, n.1, p. 25-46, jan/jun, 2006. LIMA, Ivaldo. A Geografia e o Resgate da Antigeopolitica. In: Revista Espaço Aberto, PPGG - UFRJ, v. 3, n. 2, p. 149-168, 2013.

MARANDOLA JR., Eduardo. Heidegger e o pensamento Fenomenológico em Geografia: sobre os modos Geográficos de existência. In: Revista Geografia, Rio Claro - São Paulo, v. 37, n. 1, p. 81-94, jan./abr. 2012. Identidade e autenticidade dos lugares: o pensamento de Heidegger em Place and Placelessness, de Edward Relph. In: Revista Geografia, Rio Claro, v.41, n.1, p.5-15, jan./abr. 2016.

MARIA, Yanci Ladeira. Paisagem e espaço: conceitos-chave da ciência geográfica ressignificados a partir da crítica aos paradigmas da sociedade moderna e ocidental como a dicotomia entre cultura e natureza e o discurso de narrativa única In: GOMES, Ingrid Aparecida (Org.). A produção do conhecimento geográfico. V. 5. Ponta Grossa (PR): Atena, 2018, p. 85-94. MCCLOUD, Scott. Desvendando os quadrinhos. Tradução Helcio de Carvalho, Marisa do Nascimento Paro. São Paulo: Makron Books, 1995. MENDONÇA, Márcio José; REIS, Luis Carlos Tosta. Percepção do espaço geográfico nos quadrinhos. In: Revista $9^{a}$ Arte, São Paulo, vol. 5, n. 2, $2^{\circ}$ sem. 2016.

MOREIRA, Marco Antonio. Aprendizagem significativa: um conceito subjacente. In: Revista Meaningful Learning Review, V. 1(2), p. 25-46, 2011. MORIN, Edgar. Os sete saberes necessários à educação do futuro. Tradução de Catarina Eleonora F. da Silva e Jeanne Sawaya; revisão técnica de Edgard de Assis Carvalho. 2. Ed. São Paulo: Cortez; Brasília: UNESCO, 2000.

MOURA, Jeani Delgado Paschoal; MARANDOLA JR., Eduardo. A geografia dos riscos nos cenários da prática docente: limites e potencialidades para a educação geográfica. In: Revista Geografia, Rio Claro / São Paulo, v. 41, n. 2, p. 297-312, mai/ago. 2016.

NICOLAU, Vitor; MAGALHÃES, Henrique. As tirinhas e a cultura da 
convergência: um estudo sobre a adaptação deste gênero dos quadrinhos às novas mídias In: Os quadrinhos na era digital: Hqtrônicas, webcomics e cultura participativa / Lucio Luiz, (organizador). - Nova Iguaçu, RJ: Marsupial Editora, 2013 (p.63-81).

OLIVEIRA, Luiz Fernandes de; CANDAU, Vera Maria Ferrão. Pedagogia decolonial e educação antirracista e intercultural no Brasil. In: Educação em Revista, Belo Horizonte, v. 26, n. 01, p. 15-40, 2010.

PINHEIRO NETO, José Elias; PACHECO, Lara Ferraz Rocha. Geografia e arte: representações em algumas paisagens cabralinas In: GOMES, Ingrid Aparecida (Org.). A produção do conhecimento geográfico. V. 2. Ponta Grossa (PR): Atena, 2018, p. 157-167.

ROUTLEDGE, Paul. Going globile: spatiality, embodiment, and media-tion in the Zapatista insurgency In: Rethinking Geopolitics. Edited by Gearóid Ó Tuathail and Simon Dalby. Taylor\&amp;Francis e-Library, 2002, p. 240-261.

TUAN, Yi-Fu. Realism and fantasy in art, history, and geography. In: Annals of the Association of Geographers, v. 80, n. 3, sep/1990, p. 435-446.

TUATHAIL, Gearóid Ó. At the end of geopolitics? Reflections on a plural problematic at the century's end. In: Alternatives, n. 22, p. 35-55, 1997. Understanding Critical Geopolitics: Geopolitics and Risk Security. In: Geopolitics, Geography and Strategy. Editors Colin S. Gray, Geoffrey Sloan. Frank Cass Publishers, p. 107-125, 1999.

; DALBY, Simon. Introduction. In: Rethinkin geopolitcs. Taylor \&amp; Francis e Library, p.1-16, 2002.

PENNA, Camila. Paulo Freire no pensamento decolonial: um olhar pedagógico sobre a teoria pós-colonial latino-americana. In: Revista de Estudos \&amp; pesquisas sobre as Américas, v. 8, n. 2, 2014.

PELIZZARI, Adriana et al. Teoria da aprendizagem significativa segundo Ausubel. In: Revista PEC, Curitiba, v. 2, n. 1, p. 37-42, jul. 2001-jul. 2002. PEREIRA, Daniel Esteves Macedo. Por mais um dia com Zapata. São Paulo: Zapata Edições, 2015.

PEREIRA, Noemi Ferreira Felisberto; AKAICHI, Tatianne. Mídias no processo de ensino e aprendizagem. In: Congresso Internacional Interdisciplinar em Sociais e Humanidades, Foz do Iguaçu - PR; UNIOESTE, 8 a 11 de dezembro 
de 2015.

PEREIRA, Suellen Silva; ALVES, Telma Lúcia Bezerra; CABRAL, Laíse do Nascimento. Recursos midiáticos e geografia escolar: propostas metodológicas em busca da renovação no ensino. In: GeoUERJ, ano 15, n. 24, v. 2, $2^{\circ}$ sem. 2013.

PECHULA, Marcia Reami; GONÇALVES, Elizabeth; CALDAS, Graça.

Divulgação Científica: Discurso, mídia e educação. Controvérsias e perspectivas. In: Revista de estudos para el desarrollo social de la comunicación.

Redes.com, n. 7, 2013.

PERILLO, Daniella. Donald Duck \&amp; Zé Carioca - Walt Disney. 2018. (4"52s).

Disponível em: \&lt;https://www.youtube.com/watch?v=oktf8JLmSDc\&gt; Acesso em: 20 mai. 2020.

PORTILLA, Miguel León. A Mesoamérica antes de 1519. In: História da América Latina Colonial, volume I/Organização Leslie Betheli; tradução Maria Clara Cescato. 2. ed. 4. Reimpr. São Paulo: Universidade de São Paulo; Brasília, DF: Fundação Alexandre de Gusmão, p. 25-63, 2018.

POSTEMA, Bárbara. Estrutura narrativa nos quadrinhos: construindo sentido a partir de fragmentos. Tradução de Gisele Rosa. São Paulo: Peirópolis, 2018. PRESSER, Alexandra Teixeira de Rosso; SCHLÖGL, Larissa. Histórias em quadrinhos enquanto meio de comunicação eficaz. In: Razón y palavra, n. 83, jun-agosto, 2013.

QUIJANO, Aníbal. Modernidad, identidad y utopia en América Latina. In: Sociedad \&amp; política ediciones. Primera edición, Lima, p.45-69, agosto 1988. O que é essa tal de raça? In: SANTOS, Renato Emerson dos (Org.). Diversidade, espaço e relações étnico-raciais: o negro na geografia do Brasil. 3. ed., ver., ampl. coleção cultura negra e identidades. Belo Horizonte: Autêntica, 2013.

Colonialidade do poder, eurocentrismo e América Latina. In: A colonialidade do saber: eurocentrismo e ciências sociais. Perspectivas latinoamericanas. Edgardo Lander (org). Coleção Sur Sur, CLASCO, Ciudad Autônoma de Buenos Aires, Argentina, setembro 2005, p. 227-278. Colonialidade, Poder, Globalização e Democracia. In: Revista Novos Rumos, ano 17, n. 37, 2002. 
. "Bien vivir": entre el "desarrollo" y la des/colonialidad del poder. In:

Boletin de OCFAM, maio 2010.

; WALLERSTEIN, Immanuel. La americanidad como concepto, o

América en el moderno sistema mundial. In: Revista trimestral publicada por la

Organización de las Naciones Unidas para la Educación, la Ciencia y la

Cultura con la colaboración de la Comisión Española de Cooperación con la

UNESCO+ y del Centre UNESCO de Catalunya. Vol. XLIV, n. 4, p. 583-593, 1992.

QUINTERO, Pablo; FIGUEIRA, Patrícia; ELIZALDE, Paz Concha. Uma breve história dos estudos decoloniais. MASP Afterall, v. 3, 2019.

RAFFESTIN, C. O Poder. In: Por uma geografia do poder. São Paulo: Ática, 1993[1980].

RIO, Vicente Del. Paisagens, realidade e imaginário: a percepção do cotidiano. In:

Revista Paisagem Ambiente Ensaios. São Paulo, n. 7, p. 93-101, jun 1995.

RIBEIRO, Emerson. A criatividade em geografia, prática pedagógica e avaliação:

lanternas geográficas. In: GeoSaberes, Fortaleza, v. 2, n. 4, ago/dez, 2011, p. 6175.

SANGUIN, André Louis. A evolução e renovação da geografia política. In:

Boletim Geográfico. Rio de Janeiro: IBGE, n. 252, vol. 35, 1977.

SANTOS, Milton. A natureza do espaço - técnica e tempo razão e emoção. São

Paulo: Hucitec, 1996, p. 253.

SANTOS, Renato Emerson dos. Falando de colonialidade no Ensino de

Geografia. In: PORTUGAL, Jussara Fraga (organizadora). Educação geográfica: temas contemporâneos. Salvador: EDUFBA, 2017.

SANTOS, Roberto Elísio. Zé Carioca e a Cultura Brasileira. In: XXV Congresso Brasileiro de Ciências da Comunicação. INTERCOM - Sociedade Brasileira de Estudos Interdisciplinares da Comunicação, Salvador/BA, 1 a 5 set. 2002.

SANTOS, Tamires Dias. Theodor Adorno: uma crítica à indústria cultural. In:

Revista Trágica: estudos de filosofia da imanência. $2^{\circ}$ quadrimestre de 2014, v. 7, n. 2, p. 25-36.

SERVILHA, Mateus de Moraes. Região, colonialidade e subdesenvolvimento. In:

CRUZ, Valter do Carmo; OLIVEIRA, Denílson Araújo de (organização).

Geografia e giro descolonial: experiências, idéias e horizontes de renovação do pensamento crítico. 1. ed. Rio de Janeiro: Letra Capital, 2017. 
SILVA, Anaxsuell Fernando; PROCÓPIO, Carlos Eduardo Pinto. Colonialidade do crer, do saber e do sentir: apontamentos para um debate epistemológico a partir do sul e com o sul. In: Revista de Ciências Sociais, Fortaleza, v. 50, n. 2, jul/out, 2019, p. 15-30.

SILVA, Matheus Moura; FRANCO, Edgar. Processo criativo em história em quadrinhos: provocação e resposta - uma análise comparativa. In: $1^{\mathrm{a}}$ Jornadas Internacionais de Histórias em Quadrinhos, Escola de Comunicação e Artes. Universidade de São Paulo, ago. 2011.

SOUZA, Claudia Rocha Fonseca; QUEIROZ, Antônia Márcia. A utilização dos meios de comunicação do ensino da geografia. In: Revista Eletrônica Geoaraguaia, Barra do Graças-MT, v. 2, n. 1, p. 62-85, jan/jul, 2012. STOLTZ, Tania. Mídia. Cognição e educação. In: Educar, Curitiba: UFPR, n. 26, p. $147,2005$.

TAKEI, George; KISINGER, Justin; SCOTT, Steven. Eles nos chamavam de inimigo. Arte de Harmony Becker; tradução de Érico Assis, $1^{a}$ ed., São Paulo: Devir, 2019.

TERUYA, Teresa Kazuko. Sobre mídia, educação e estudos culturais. In: MACIEL, Lizete Shizue Bomura; MORI Nerli Nonato Ribeiro (Org.) Pesquisa em educação: múltiplos olhares. Maringá: Eduem, 2009.

TOLEDO, Júlia. Asterix entre os acadêmicos: o uso dos quadrinhos para uma análise dos conceitos de geografia. Viçosa: UFV, 2011.

TUFTE, Birgitte; CHRISTENSEN, Ole. Mídia-educação - entre a teoria e a prática. In: Perspectiva, Florianópolis, v. 27, n. 1, 97-118, jan./jun. 2009.

URTEAGA, Eguzki. Las series también tienen una geopolítica. In: Geopolitica(s) Revista de estudos sobre espacio y poder, 8(2), 2017, p. 299-313.

WALSH, Catherine. Shifting the geopolitics of critical knowledge: Decolonial thought and cultural studies 'others' in the Andes. In: Cultural Studies, v. 21, n. 2-3, mar/mai, 2007, p. 224-239.

WALSH, Catherine. Entretejiendo lo pedagógico y lo decolonial: luchas, caminhos y siembras de reflexión-acción para resistir, (re)existir y (re)vivir. Colombia: Editora Alternativas, 2017.

WALSH, Catherine. Interculturalité critique et pédagogie décoloniale: s'insurger, re-exister et re-vivre. In: ROUGIER, Claude Bouguignon (org.); COLIN, Philippe; GROSFOGUEL, Ramón. Penser l'envers obscur de la modernité: une 
anthologie de la pensée décoloniale latino-américaine. Presses Universitaires de Limoges, 2014, p. 75-99.

YOUNG, Michael F. D. Porque o conhecimento é importante para as escolas do século XXI? Tradução de Tessa Bueno, revisão de Cláudia Valentina Assumpção Galian. In: Cadernos de pesquisa, v. 46, n. 159, p. 18-37, jan/mar, 2016.

D. O futuro da educação em uma sociedade do conhecimento: o argumento radical em defesa de um currículo centrado em disciplinas. Tradução de Laura Beatriz Áreas Coimbra; Revisão Técnica de Antônio Flavio Barbosa Moreira. In: Revista Brasileira de Educação, v. 16, n. 48, set-dez, p. 609-623, 2011.

D. Para que servem as escolas? In: Revista Educação \& Camp; Sociedade, Campinas, v. 28, n. 101, 2007, p. 1287-1302. Disponível em: \&lt;http://www.cedes.unicamp.br\&gt;. Acesso em: 10 mai. 2020. 
Anexo I
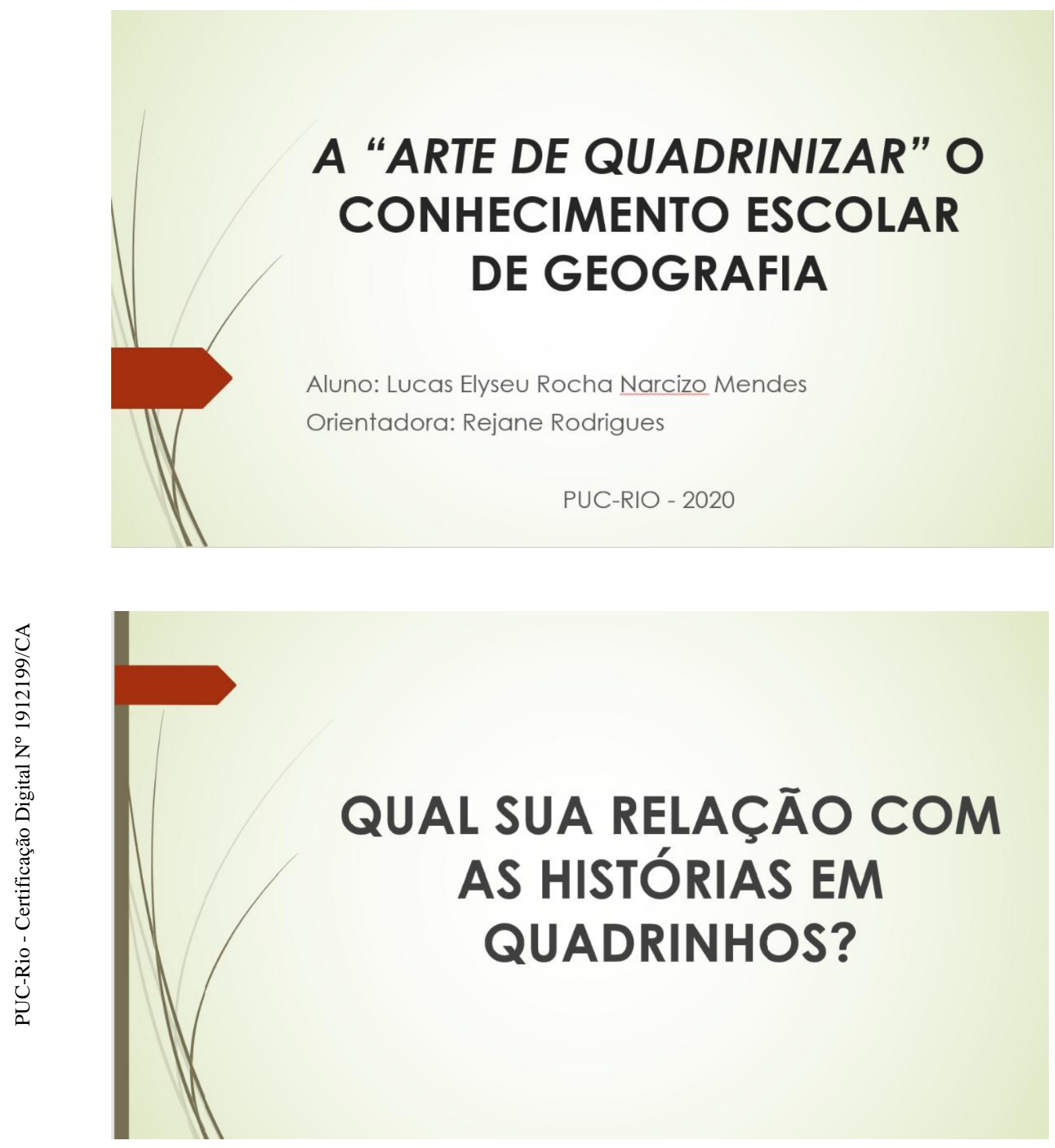

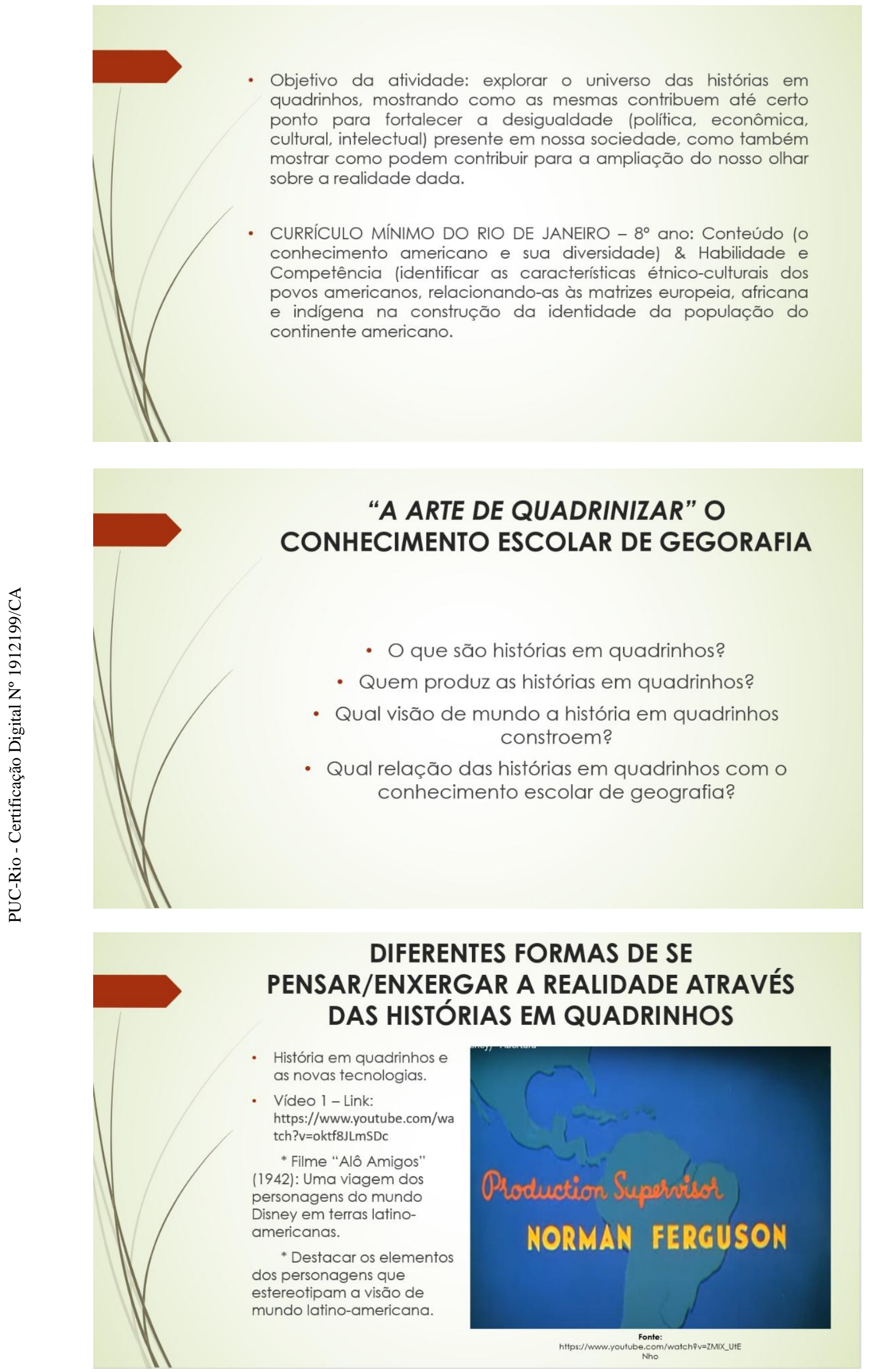


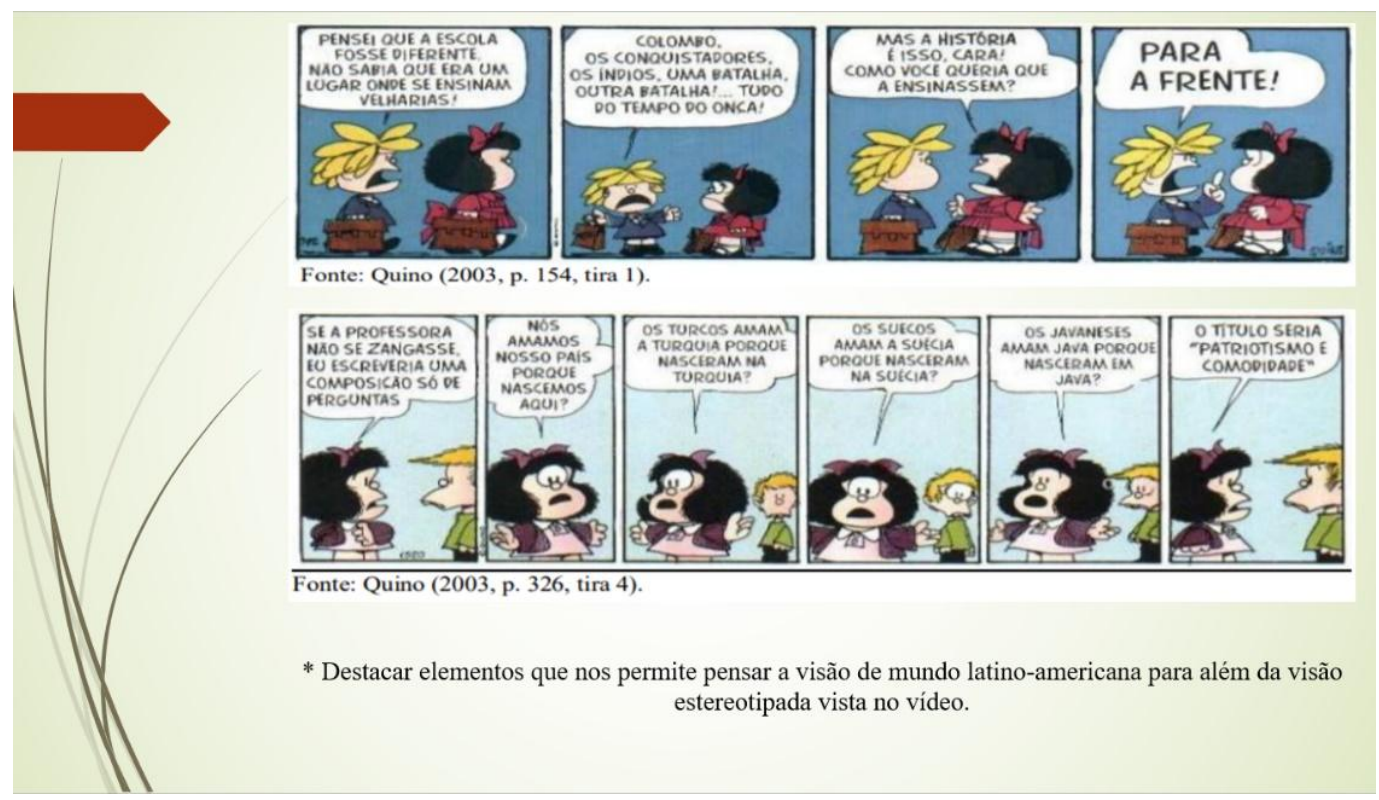

REFERENCIAS:

- BRUNETTI, Ivan. A arte de quadrinizar: filosofia e prática. São Paulo: Editora WMF Martins Fontes, 2013.

- GIROTTO, Eduardo Donizeti; SANTOS, David Augusto. A geopolítica e o ensino de geografia: estratégias didáticas para a retomada do diálogo. Geografia Ensino \& Pesquisa, v.15, n.3, set/dez, 2011

- SANTOS, Roberto Elísio. Zé Carioca e a Cultura Brasileira. INTERCOM - Sociedade Brasileira de Estudos Interdisciplinares da Comunicação, XXV Congresso Brasileiro de Ciências da Comunicação - Salvador/BA - 1 a 5, set, 2002. 


\section{Anexo II}

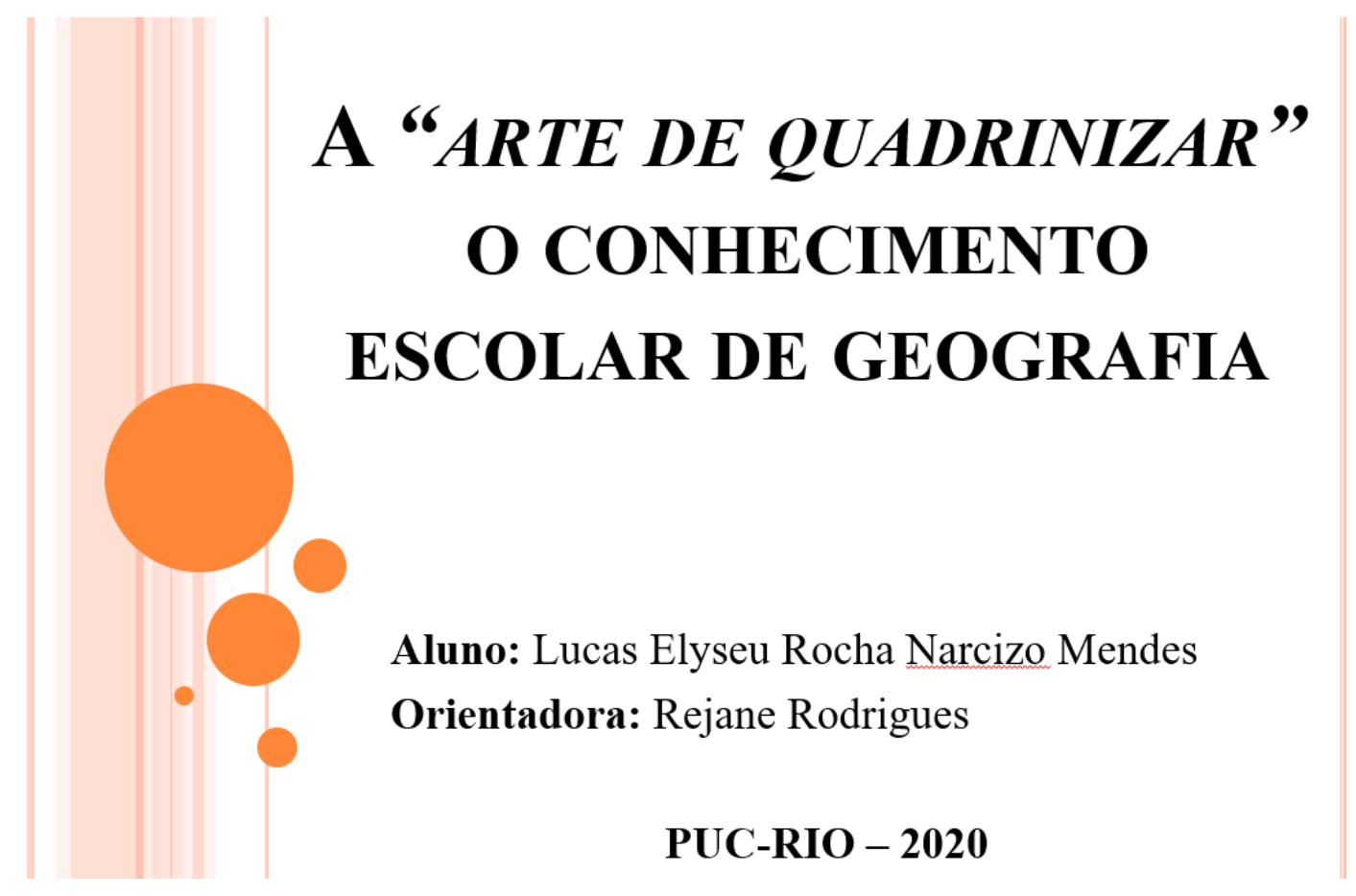

SÉCULO XIX (1833) - RODOLPHE TÖPFFER

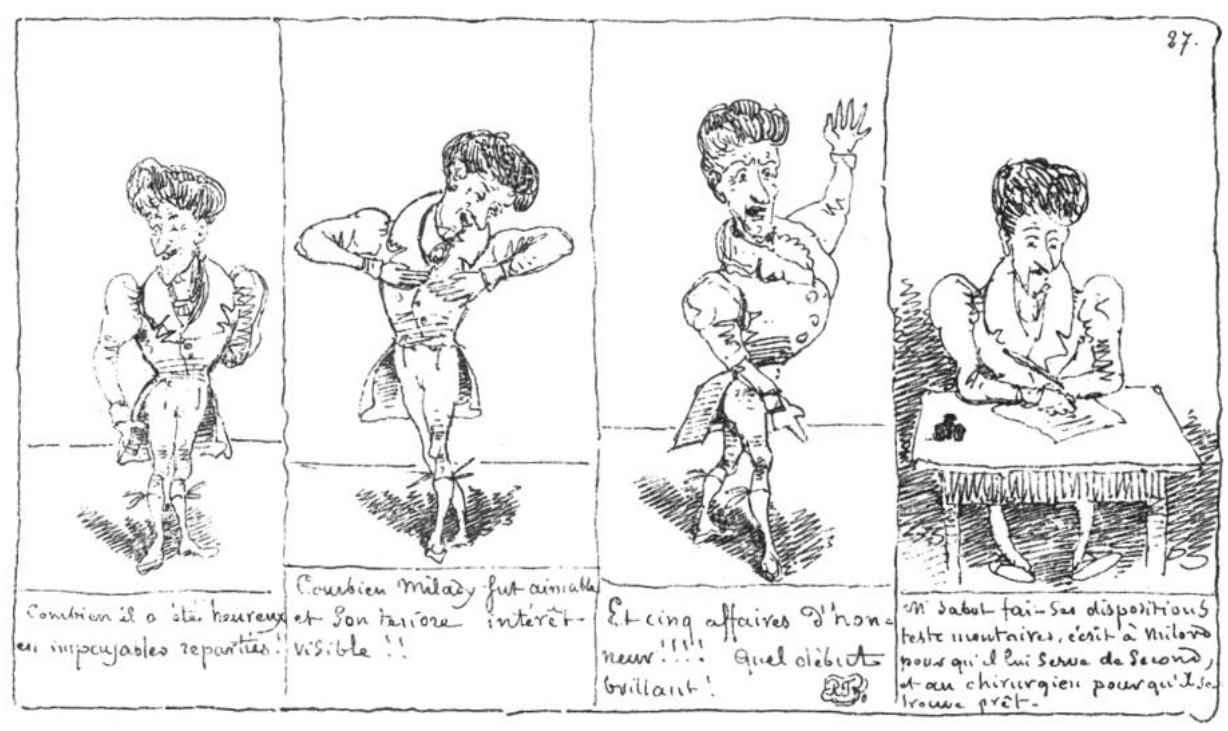

Fonte: https://www.torredevigilancia.com/mr-jabot-primeirahq-do-mundo-chega-ao-brasil-em-marco/ 


\section{SÉCULO XIX (1896) - RICHARD FELTON OUTCAULT ("YELLOW KID”)}

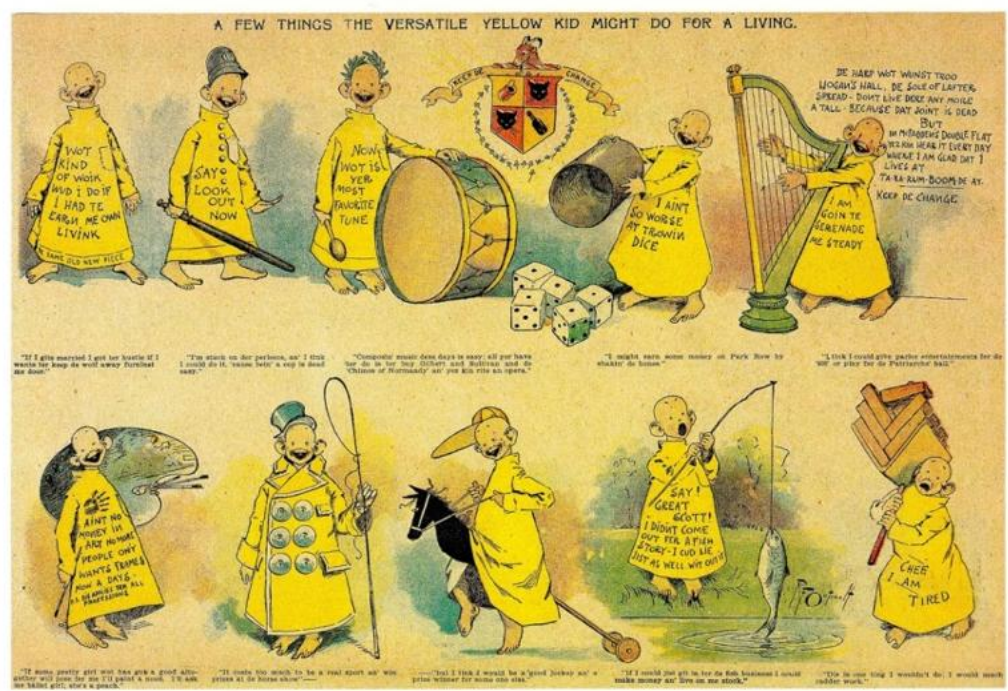

Fonte: http://mparaschos.com/Courses/yk.html

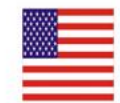
SÉCULO XX (1905) - O TICO-TICO

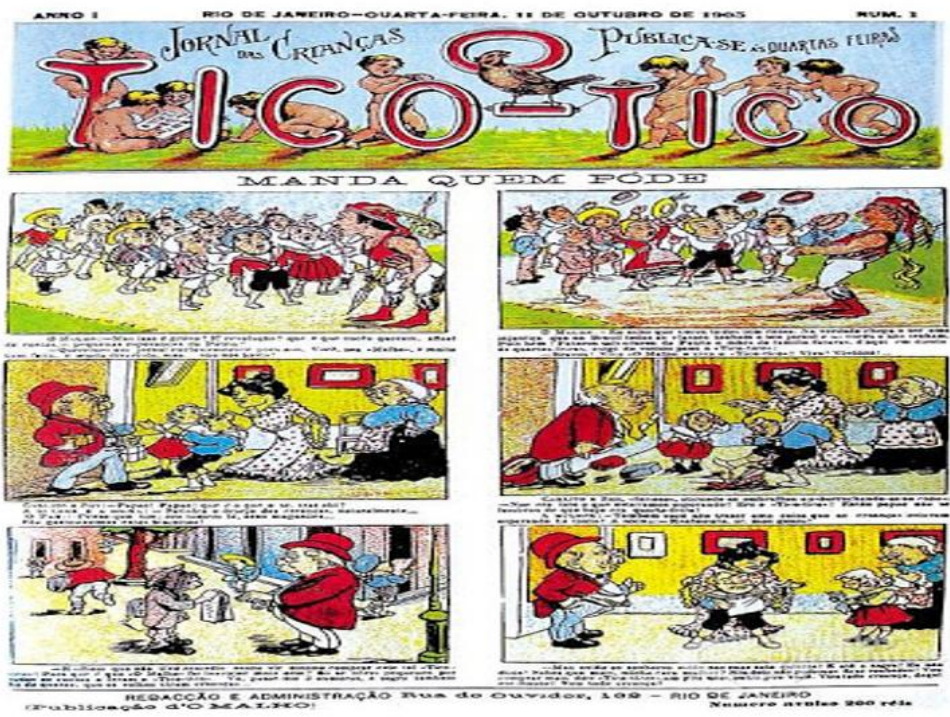

Fonte: http://www.guiadosquadrinhos.com/edicao/tico-tico-o-n-1/ti173100/24467 


\section{SÉCULO XX (1929) - HERGÉ}
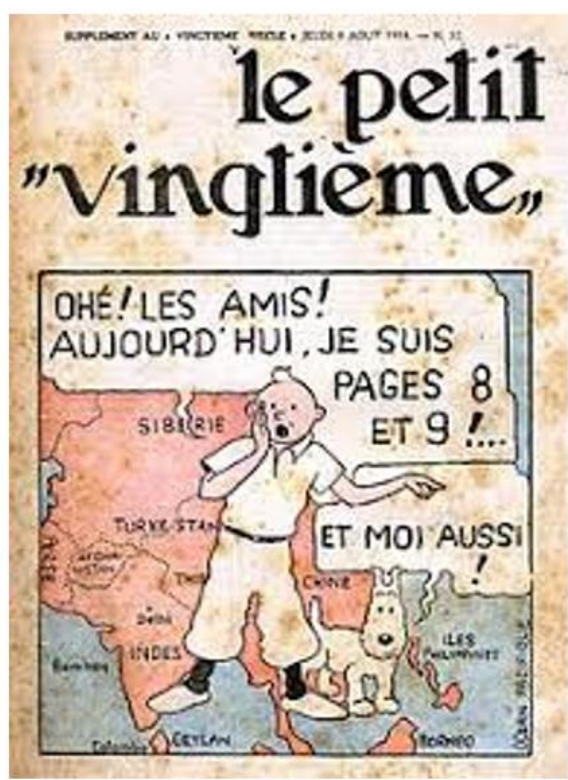

Fonte:

http://tintin.wikia.com/wiki/Le Petit Vingti $\%$ C3 $\%$ A8me

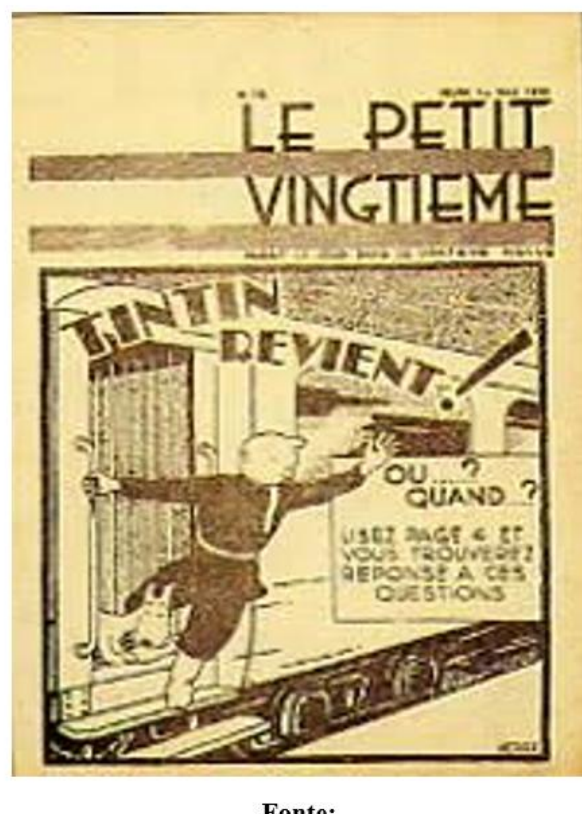

Fonte:

https://en.wikipedia.org/wiki/The_Adventures_of -Tintin
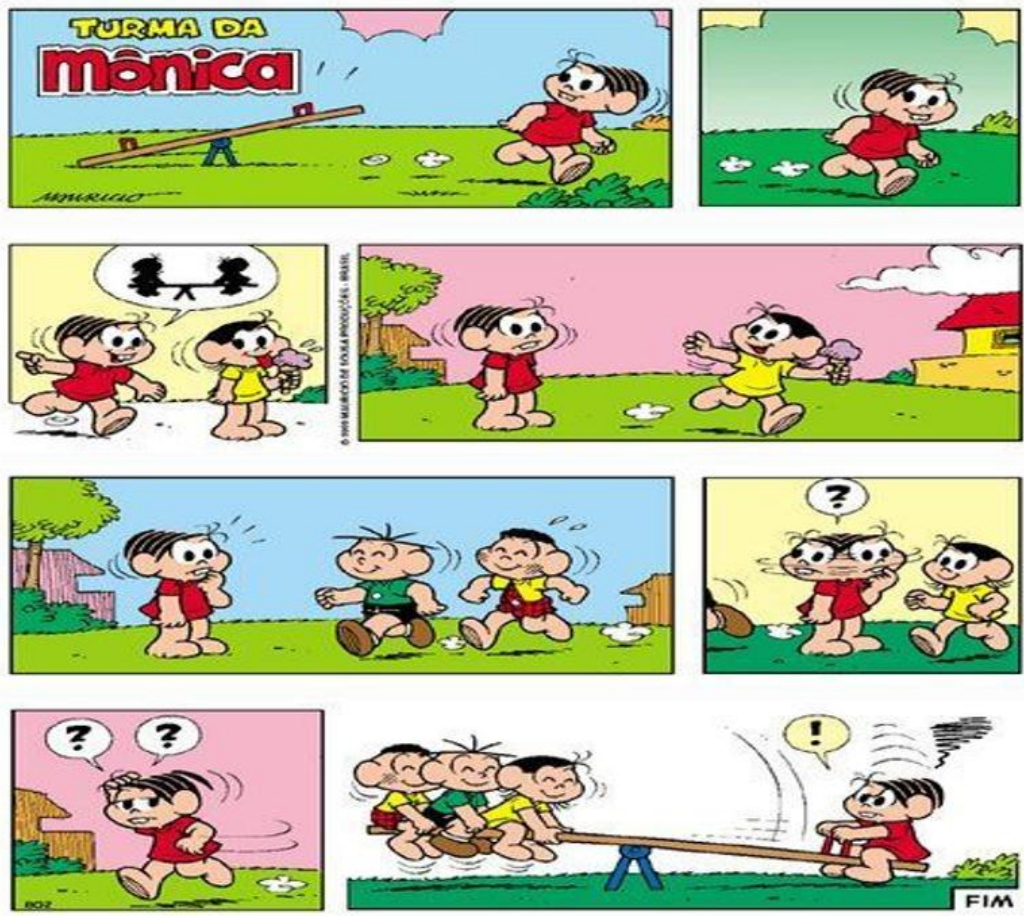

Fonte: https://br.pinterest.com/pin/482025966354565469/ 
SÉCULO XX - MARCELO D'SALETTE
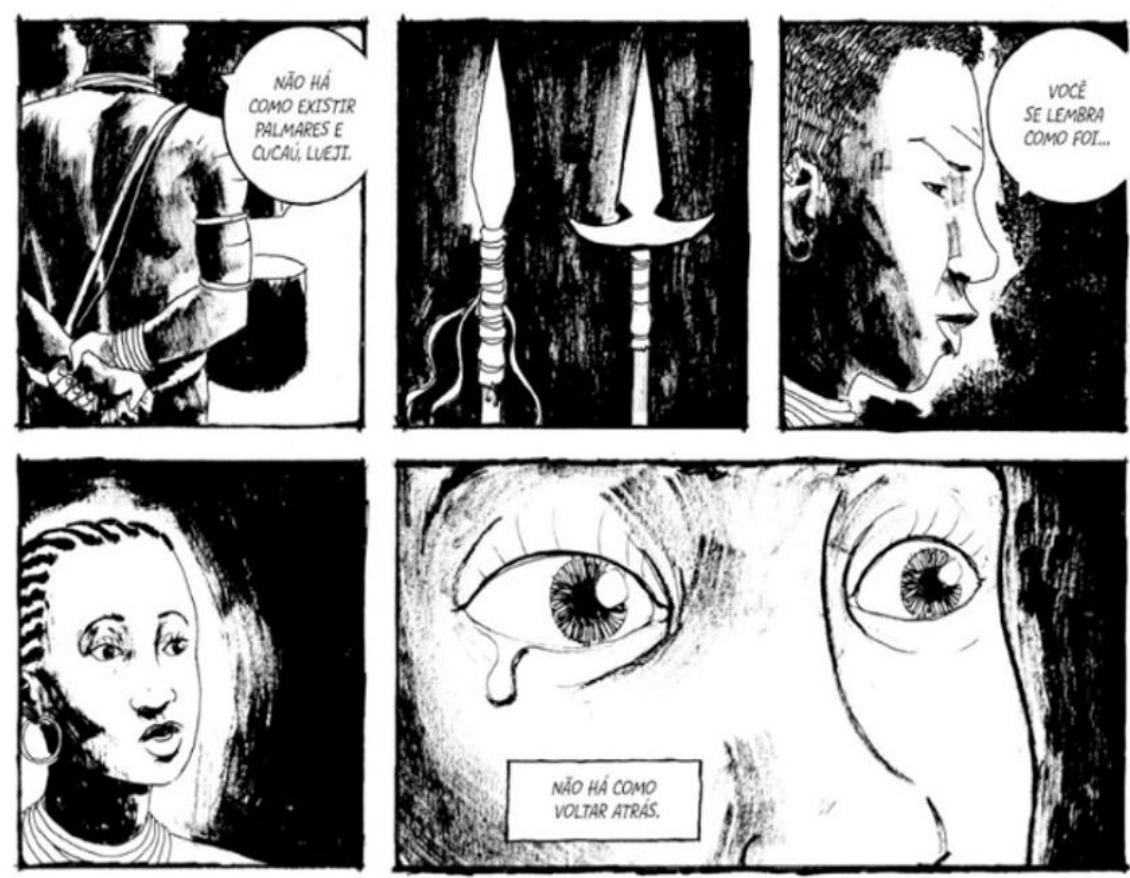

Fonte: https://vitralizado.com/hq/papo-com-marcelo-dsalete-o-autor-angola-janga-temos-umasubcidadania-praticada-e-reafirmada-cotidianamente-o-poder-permanece-na-mao-de-poucos/ 